\title{
Conjugate Additions to Phenylglycinol-Derived Unsaturated $\delta$-Lactams. Enantioselective Synthesis of Uleine Alkaloids
}

\author{
Mercedes Amat, ${ }^{*} \dagger$ Maria Pérez,${ }^{\dagger}$ Núria Llor,${ }^{\dagger}$ Carmen Escolano, ${ }^{\dagger}$ F. Javier Luque, ${ }^{\ddagger}$ \\ Elies Molins, ${ }^{\S}$ and Joan Bosch*,† \\ Laboratory of Organic Chemistry and Department of Physical Chemistry, Faculty of Pharmacy, \\ University of Barcelona, 08028 Barcelona, Spain, and Institut de Ciència de Materials (CSIC), \\ Campus UAB, 08193 Cerdanyola, Spain \\ amat@ub.edu; joanbosch@ub.edu
}

Received July 27, 2004

\begin{abstract}
The stereochemical outcome of the conjugate addition of a variety of stabilized nucleophiles (2indoleacetic enolates and sulfur-stabilized anions) to the phenylglycinol-derived unsaturated lactams trans-2, cis-2, and its 8-ethyl-substituted analogue $\mathbf{1 0}$ is studied. The factors governing the exo or endo facial stereoselectivity are discussed. This methodology provides short synthetic routes to either cis- or trans-3,4-disubstituted enantiopure piperidines as well as efficient routes for the enantioselective construction of the tetracyclic ring system of uleine alkaloids, both in the normal and 20-epi series. The formal total synthesis of several alkaloids of this group is reported.
\end{abstract}

The alkaloids of the uleine group constitute a comparatively small group of indole alkaloids lacking the twocarbon link between the indole 3-position and the basic nitrogen atom, present in the greater part of monoterpenoid indole alkaloids. ${ }^{1}$ These alkaloids are characterized by the presence of a tetracyclic 1,5-methanoazocino[4,3-b]indole system bearing an ethyl substituent at the bridge carbon (Figure 1).

Biogenetically, the alkaloids of the uleine group are formed from stemmadenine, by fragmentation of the tryptamine bridge followed by isomerization of the resulting exocyclic iminium species to a more stable conjugated iminium cation and subsequent electrophilic cyclization on the indole 3-position ${ }^{2}$ (Scheme 1). While the absolute configuration of the bridgehead C-15 position $^{3}$ results from their biogenetic origin from secologanin, there are alkaloids with each of the two possible configurations at C-20: $\mathrm{H}_{15}$ and $\mathrm{H}_{20}$ are cis, and consequently the ethyl substituent is equatorial with respect to the piperidine ring, in most of the alkaloids of this group, but trans in the 20-epi series.

Although the uleine alkaloids have received considerable synthetic attention, ${ }^{1}$ their enantioselective synthesis has been little explored, and only one enantioselective

$\dagger$ Laboratory of Organic Chemistry.

¥ Laboratory of Physical Chemistry.

$\S$ Institut de Ciència de Materials.

(1) (a) Joule, J. A. Indoles. The Monoterpenoid Indole Alkaloids; Saxton, J. E., Ed. In The Chemistry of Heterocyclic Compounds; Weissberger, A., Taylor, E. C., Eds.; Wiley: New York, 1983; Vol. 25, Part 4, Chapter 6. (b) Alvarez, M.; Joule, J. A. Monoterpenoid Indole Alkaloids; Saxton, J. E., Ed. In The Chemistry of Heterocyclic Compounds; Taylor, E. C., Ed.; Wiley: Chichester, 1994; Suppl. to Vol. 25, Part 4, Chapter 6. (c) Alvarez, M.; Joule, J. A. In The Alkaloids; Cordell, G. A., Ed.; Academic Press: New York, 2001; Vol. 57, Chapter 4.

(2) Atta-ur-Rahman; Basha, A. Biosynthesis of Indole Alkaloids; Clarendon Press: Oxford, 1983.

(3) The biogenetic numbering is used throughout this paper for all tetracyclic compounds. Le Men, J.; Taylor, W. I. Experientia 1965, 21, 508.

10.1021/jo0487101 CCC: $\$ 27.50$ @ 2004 American Chemical Society Published on Web 11/06/2004

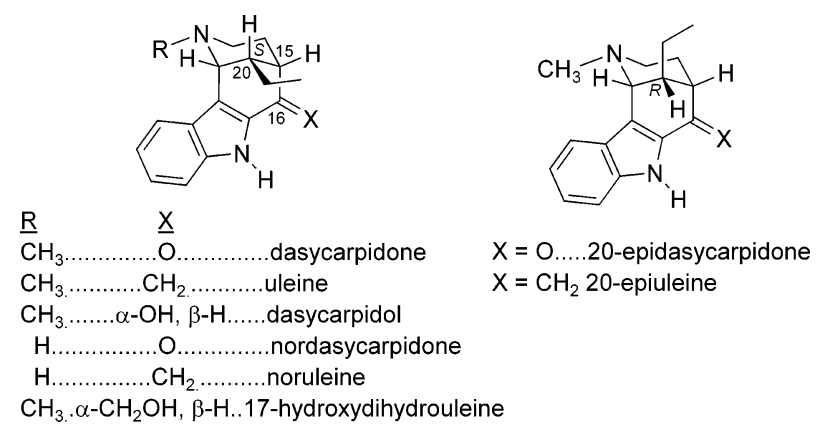

FIGURE 1. Uleine alkaloids.

SCHEME 1. Biosynthesis of Uleine Alkaloids

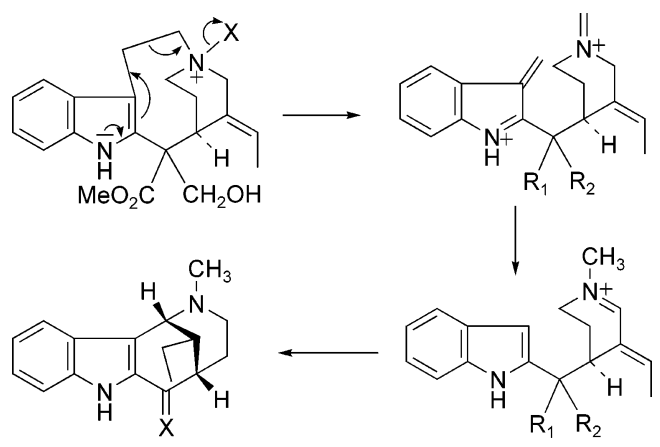

Uleine alkaloids

total synthesis of alkaloids of this group has been reported so far. ${ }^{4}$ A crucial problem associated with the synthesis of these alkaloids is the control of the absolute (and relative) configuration at $\mathrm{C}_{15}$ and $\mathrm{C}_{20}$.

(4) (a) Saito, M.; Kawamura, M.; Hiroya, K.; Ogasawara, K. Chem. Commun. 1997, 765. (b) Tanaka, K.; Katsumura, S. J. Am. Chem. Soc. 2002, 124, 9660. (c) Jiricek, J.; Blechert, S. J. Am. Chem. Soc. 2004, 126,3534 . 


\section{SCHEME 2. Synthetic Strategy}
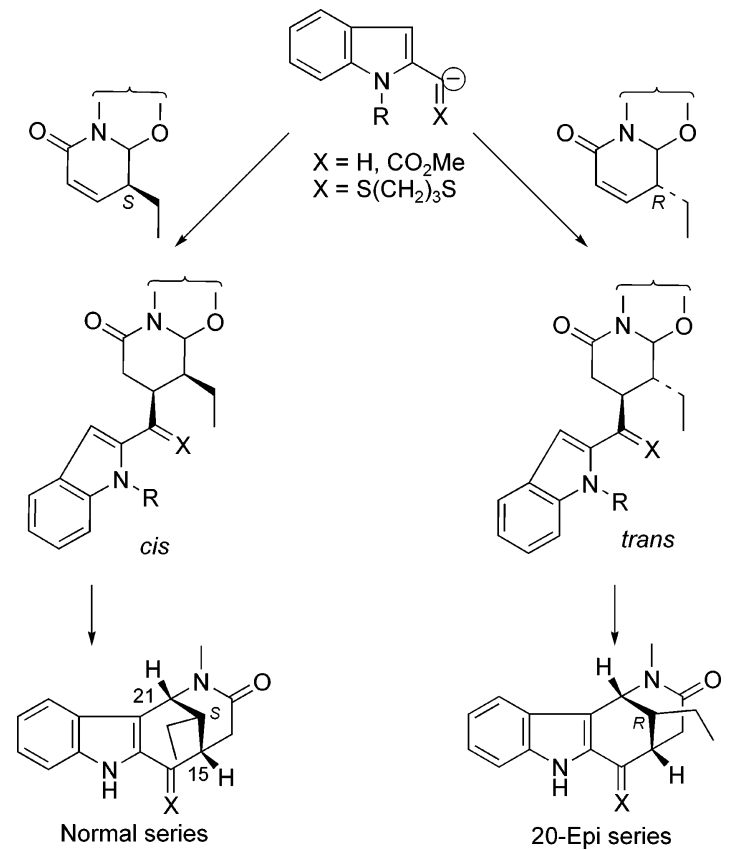

In the context of our studies on the enantioselective synthesis of piperidine-containing derivatives from phenylglycinol-derived bicyclic lactams,${ }^{5}$ we devised a general synthetic route to the uleine alkaloids, in which the key step would be the stereocontrolled conjugate addition of an indolylmethyl anion equivalent to an appropriate $\gamma$-ethyl $\alpha, \beta$-unsaturated $\delta$-lactam (bond formed $\mathrm{C}_{15}-\mathrm{C}_{16}$ ). A subsequent biomimetic cyclization on the indole 3-position of the masked acyl iminium ion present in the resulting enantiopure cis or trans 4,5-disubstituted 2-piperidone (bond formed $\mathrm{C}_{7}-\mathrm{C}_{21}$ ) would lead to the natural products, either in the normal or epi series, respectively (Scheme 2). ${ }^{6}$ As a consequence of the bridgehead character of the stereocenters at C-15 and C-21, the absolute configuration of the stereogenic center generated at the piperidine 4-carbon (C-15) after the conjugate addition reaction would determine that of $\mathrm{C}-21$ in the cyclization leading to the tetracyclic system of uleine alkaloids.

In recent work, ${ }^{5 a, 7}$ we have demonstrated that the diastereomeric unsaturated lactams cis-1 and trans-1 undergo conjugate addition of organocuprates with opposite facial selectivity, a result that was rationalized by considering that the configuration of the C-8a stereocenter determines the conformation of the six-membered ring and that the attack of the nucleophile to these conformationally rigid lactams occurs under stereoelec-

(5) (a) Amat, M.; Bosch, J.; Hidalgo, J.; Cantó, M.; Pérez, M.; Llor, N.; Molins, E.; Miravitlles, C.; Orozco, M.; Luque, J. J. Org. Chem. 2000, 65, 3074. (b) Amat, M.; Cantó, M.; Llor, N.; Ponzo, V.; Pérez, M.; Bosch, J. Angew. Chem., Int. Ed. 2002, 41, 335. (c) Amat, M.; Llor, N.; Hidalgo, J.; Escolano, C.; Bosch, J. J. Org. Chem. 2003, 68, 1919. (d) Amat, M.; Escolano, C.; Lozano, O.; Llor, N.; Bosch, J. Org. Lett. 2003, 5, 3139 and references therein. For reviews, see: (e) Meyers, A. I.; Brengel, G. P. Chem. Commun. 1997, 1. (f) Groaning, M. D.; Meyers, A. I. Tetrahedron 2000, 56, 9843.

(6) For a preliminary communication of this part of the work, see: Amat, M.; Pérez, M.; Llor, N.; Martinelli, M.; Molins, E.; Bosch, J. Chem. Commun. 2004, 1602.

(7) Amat, M.; Pérez, M.; Llor, N.; Lago, E.; Molins, E. Org. Lett. $\mathbf{2 0 0 1}, 3,611$.
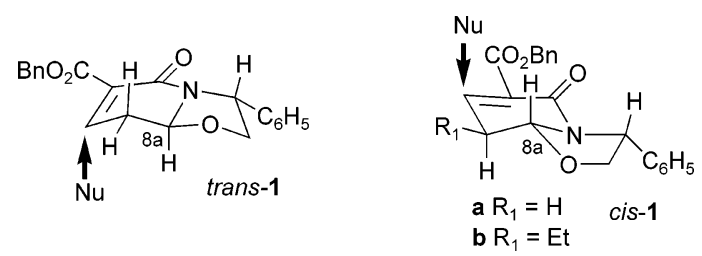

FIGURE 2. Stereoelectronic control.

tronic control, ${ }^{8}$ axial to the electrophilic carbon of the conjugate double bond (Figure 2). These conjugate additions constitute the key step of an enantiodivergent synthesis of both enantiomers of the antidepressant drug paroxetine (a trans-3,4-disubstituted piperidine).

\section{Results and Discussion}

Taking into account that $\alpha, \beta$-unsaturated lactams are poor Michael acceptors ${ }^{9}$ and that there are few examples of such conjugate additions to $\delta$-lactams lacking an additional electron-withdrawing group on the nitrogen and/or in conjugation with the double bond, ${ }^{10}$ to check the viability of the proposed conjugate addition-cyclization sequence, in our initial studies we examined the stereochemical outcome of the conjugate addition of 2-indoleacetate enolates to the model lactams cis-2 and trans-2, which lack the ethyl substituent present in the natural products.

Reaction of lactam trans-2 with the enolate of methyl 1-methyl-2-indoleacetate (3a) gave (64\%) lactam ester 4a as a mixture of epimers (3:2 ratio) at the isomerizable stereocenter $\alpha$ to the ester group, which could be separated by column chromatography (Scheme 3 ). The cyclization step was carried out in the presence of $\mathrm{TiCl}_{4}$, using each epimer separately. The major isomer led to tetracycle (16S)-5a (44\%), whereas the minor one led to the C-16 epimer (16R)-5a (50\%), ${ }^{11}$ thus indicating that the conjugate addition had taken place on the exo face of lactam trans-2 with excellent facial selectivity.

The relative configuration of $\mathrm{C}-16$ in these tetracycles was deduced from the $\mathrm{H}_{15}-\mathrm{H}_{16} J$ value and from the

(8) (a) Deslongchamps, P. Stereoelectronic Effects in Organic Chemistry; Pergamon Press: Oxford, 1983; p 221. (b) Perlmutter, P Conjugate Addition Reactions in Organic Synthesis; Pergamon Press: Oxford, 1992; p 25.

(9) (a) Nagashima, H.; Ozaki, N.; Washiyama, M.; Itoh, K. Tetrahedron Lett. 1985, 26, 657. (b) Hagen, T. J. Synlett 1990, 63.

(10) For the addition of organocuprates, see: (a) Overman, L. E.; Robichaud, A. J. J. Am. Chem. Soc. 1989, 111, 300. (b) Herdeis, C.; Kaschinski, C.; Karla, R. Tetrahedron: Asymmetry 1996, 7, 867. (c) Muller, M.; Schoenfelder, A.; Didier, B.; Mann, A.; Wermuth, C.-G. Chem. Commun. 1999, 683. (d) Deiters, A.; Martin, S. F. Org. Lett. 2002, 4, 3243. (e) Lerchner, A.; Carreira, E. M. J. Am. Chem. Soc. 2002, 124, 14826. (f) Hanessian, S.; van Otterlo, W. A. L.; Nilsson, I.; Bauer, U. Tetrahedron Lett. 2002, 43, 1995. (g) Cossy, J.; Mirguet, O.; Gomez Pardo, D.; Desmurs, J.-R. New J. Chem. 2003, 27, 475. For the addition of stabilized anions, see: (h) Stork, G.; Schultz, A. G. J. Am. Chem. Soc. 1971, 93, 4074. (i) Herrmann, J. L.; Richman, J. E.; Schlessinger R. H. Tetrahedron Lett. 1973, 2599. (j) Kametani, T.; Surgenor, S. A.; Fukumoto, K. J. Chem. Soc., Perkin Trans. 1 1981, 920. (k) Takano, S.; Sato, M.; Ogasawara, K. Heterocycles 1981, 16, 799. (1) Naito, T.; Miyata, O.; Ninomiya, I. Heterocycles 1987, 26, 1739. (m) Fujii, T.; Ohba, M.; Sakaguchi, J. Chem. Pharm. Bull. 1987, 35, 3628. (n) Forns, P.; Diez, A.; Rubiralta, M.; Solans, X.; Font-Bardia, M. Tetrahedron 1996, 52, 3563. (o) Etxarri, B.; González-Temprano, I.; Manteca, I.; Sotomayor, N.; Lete, E. Synlett 1999, 1486. (p) Hanessian, S.; Gomtsyan, A.; Malek, N. J. Org. Chem. 2000, 65, 5623. (q) Hanessian, S.; Seid, M.; Nilsson, I. Tetrahedron Lett. 2002, 43, 1991.

(11) In both cases, minor amounts of the respective C-16 epimer were also formed as a consequence of the epimerization occurring at the ester $\alpha$ carbon during the cyclization step. 


\section{SCHEME 3. Tetracyclic Ring System of Uleine Alkaloids}

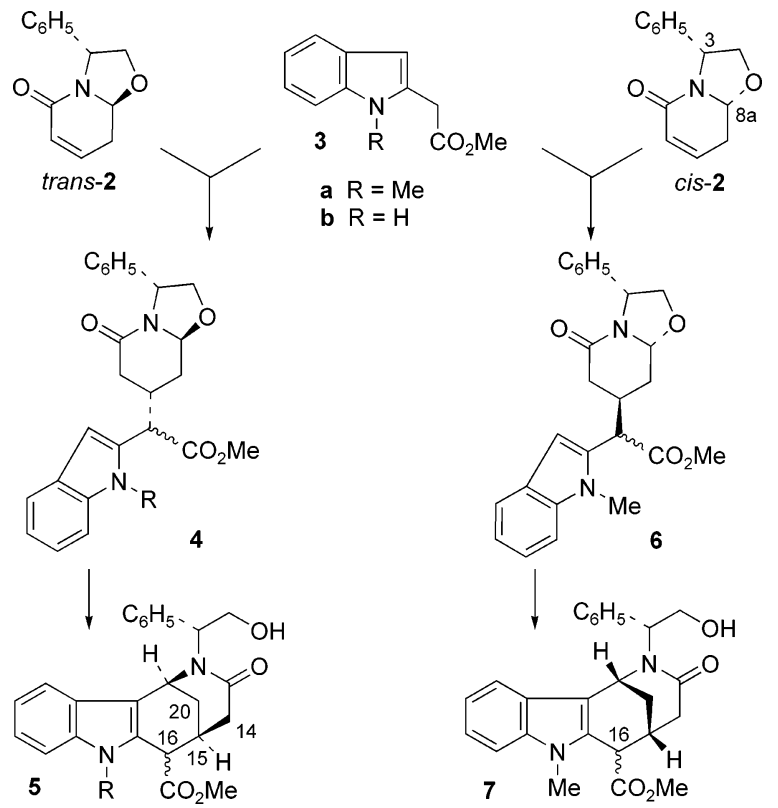

existence or absence of $\gamma$-gauche effects on C-14 and C-20 on the NMR spectra, ${ }^{12}$ whereas the absolute configuration (C-15 is $S$ ) was inferred by comparing the NMR data of tetracycles $\mathbf{5 a}$ with those of $\mathbf{1 2 a}$, whose absolute configuration was known from the X-ray analysis of its precursor $(\alpha R)$-11a (see below).

The use of the enolate of indoleacetate $\mathbf{3 b}$, unsubstituted on the indole nitrogen, led to similar results. Conjugate addition to trans-2 took place again with high exo facial stereoselectivity to give an epimeric mixture of lactam esters $4 \mathbf{b}$ (3:2 ratio; 51\%), which were separately cyclized to the respective tetracycles $(16 S)-5 b$ and (16R)-5b in $\sim 70 \%$ yield. In this series, epimerization at C-16 during cyclization occurred to a considerable extent (see the Experimental Section).

Next we investigated the stereochemical outcome of the conjugate addition-cyclization sequence from lactam cis2. The conjugate addition of ester $\mathbf{3 a}$ led again to an epimeric mixture of lactam esters 6 (3:2 ratio; $53 \%$ yield), which were separately cyclized to the respective tetracycles (16S)-7 (from the major lactam ester) and (16R)-7 without detectable epimerization at C-16. These cyclizations, involving a 3,8a-cis lactam, took place in lower yield and required harder conditions than the above cyclizations from the $3,8 \mathrm{a}$-trans isomers. ${ }^{13}$

Comparison of the NMR spectroscopic data of tetracycle (16R)-7 with those of (16S)-5a, both of them with a trans $\mathrm{H}_{15}-\mathrm{H}_{16}$ relationship, made evident that these compounds were diastereomers and, consequently, that the absolute configuration of C-15 in (16R)-7 is $R$. Similarly, (16S)-7 and (16R)-5a, both having a cis $\mathrm{H}_{15}-\mathrm{H}_{16}$ relationship, are also diastereomers, and therefore, the configuration at the piperidine 4-position in tetracycle (16S)-7 is also $R$. This allowed us to conclude that the

(12) Bennasar, M.-L.; Alvarez, M.; Lavilla, R.; Zulaica, E.; Bosch, J. J. Org. Chem. 1990, 55, 1156.

(13) For the different reactivity of 3,8a-cis and trans related lactams in $\alpha$-amidoalkylation reactions, see: Amat, M.; Escolano, C.; Llor, N.; Huguet, M.; Pérez, M.; Bosch, J. Tetrahedron: Asymmetry 2003, 14, 1679 .

\section{SCHEME 4}

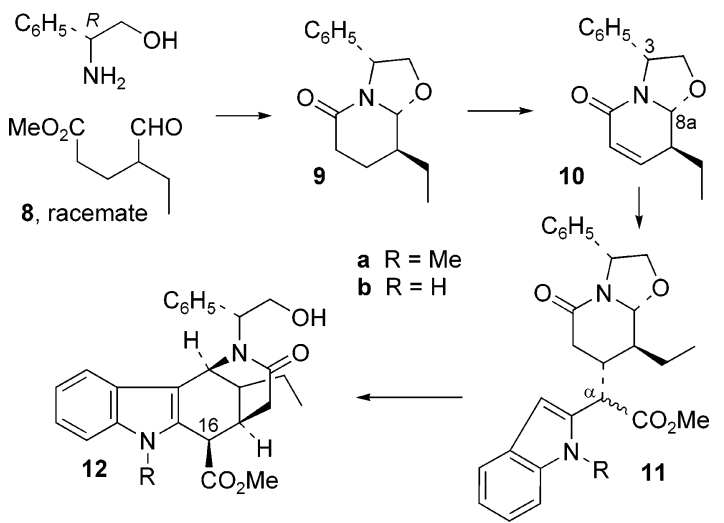

conjugate addition of $\mathbf{3 a}$ to cis-2 had also occurred on the exo face, which involves a facial stereoselectivity opposite to that observed when starting from trans-2. These results are in agreement with the stereochemical outcome of the conjugate addition of cyanocuprates to related lactams cis-1 and trans-1 ${ }^{5 a, 7}$ and can be accounted for by considering that the process is kinetically controlled..$^{14}$

Once it was demonstrated that the above approach can provide straightforward access to the tetracyclic ring system of uleine alkaloids with the natural configuration at the bridgehead carbons (e.g., 7), we extended our studies using the unsaturated lactam 10, which has the same cis-3,8a configuration as cis-2 and incorporates the ethyl substituent with the required absolute configuration for the synthesis of alkaloids in the normal C-20 series. This lactam was prepared in 55\% overall yield by cyclocondensation of $(R)$-phenylglycinol with racemic methyl 4-formylhexanoate (8), in a process involving a dynamic kinetic resolution, ${ }^{15}$ followed by generation of the carbon-carbon double bond from the resulting lactam 9 via a $\beta$-keto sulfoxide (Scheme 4). The addition of the enolate ester $\mathbf{3 a}$ to lactam $\mathbf{1 0}$ took place in excellent yield (83\%) and complete facial selectivity to give the epimeric lactam esters $(\alpha S)$-11a and $(\alpha R)$-11a (3:7 ratio). Cyclization of the major isomer also took place in excellent yield $(81 \%)$ to give tetracycle 12a. The absolute configuration of $(\alpha R)$-11a was unambiguously established by X-ray crystallography and indicated that the ethyl substituent had exerted a dramatic influence on the stereochemical course of the conjugate addition since it had occurred on the endo face of the carbon-carbon double bond to give an all-trans piperidine derivative, instead of the required cis-4,5-disubstituted 2-piperidone. ${ }^{16}$

The same stereoselectivity was observed from the enolate of the $N$-unsubstituted indoleacetate $\mathbf{3 b}$, although in this case the conjugate addition only took place in acceptable yield (40\%) in the presence of $\mathrm{CuCN}$ to give a 7:3 epimeric mixture of lactam esters $(\alpha S)-\mathbf{1 1} \mathbf{b}$ and $(\alpha R)$-11b. Both epimers were separately cyclized to give the same enantiopure tetracycle $\mathbf{1 2 b}$, thus indicating that epimerization at $\mathrm{C}-16$ from the major isomer had occurred during cyclization.

(14) Molecular mechanics (MM.; CVFF91 force field) calculations provide support to this conclusion because they indicated that the exo adducts $4 \mathbf{a}$ and $\mathbf{6}$ are less stable that the corresponding C-7 epimers. (15) For a recent review, see: Pellissier, H. Tetrahedron 2003, 59, 8291.

(16) According to MM calculations, the endo adducts $\mathbf{1 1 a}, \mathbf{2 4 b}, \mathbf{2 8 b}$, and $\mathbf{3 3 b}$ were more stable than the respective exo epimers. 


\section{SCHEME 5. Enantioselective Total Synthesis of 20-Epiuleine Derivatives}

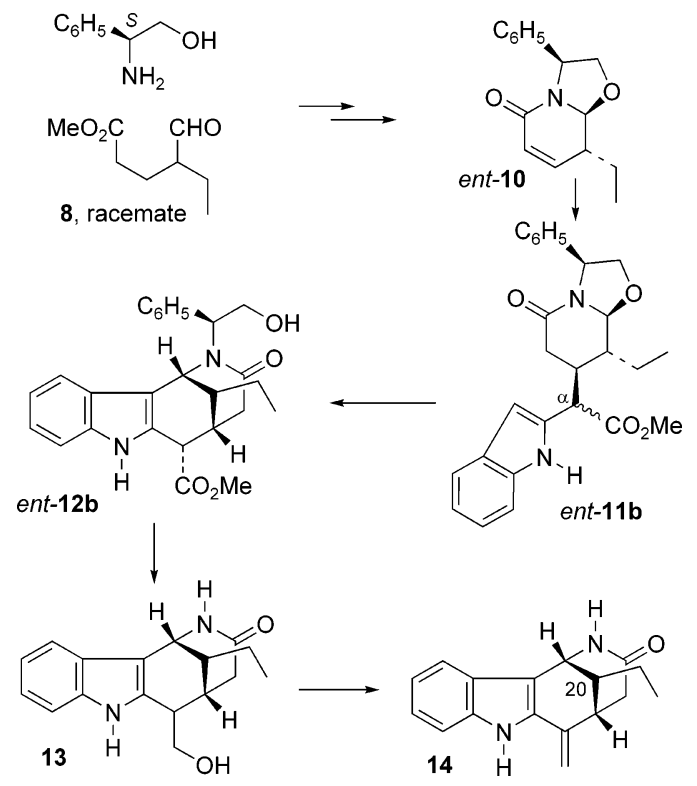

Unfortunately, the absolute configuration at the piperidine 4-position in $\mathbf{1 1}$ and, consequently, at the bridgehead carbons in tetracycles $\mathbf{1 2}$ is the opposite of that present in uleine alkaloids. However, taking advantage of the fact that both enantiomers of phenylglycinol are commercially available, the trans stereoselectivity of the above conjugate additions can provide access to tetracyclic derivatives with the natural configuration in the 20 -epi series. It is simply a matter of starting from the enantiomer of unsaturated lactam 10, which was prepared from ( $S$ )-phenylglycinol as in the above $R$-series (Scheme 5).

As expected, conjugate addition of the enolate derived from $\mathbf{3 b}$ to ent $\mathbf{- 1 0}$, followed by cyclization of the resulting epimeric mixture of lactam esters ent-11b, led to tetracycle ent-12b, which was chemoselectively reduced with $\mathrm{Na} /$ liq $\mathrm{NH}_{3}$ to alcohols 13 (64\%; epimeric mixture) and then converted (53\%) to the nor-20-epiuleine derivative $\mathbf{1 4}$ via the corresponding mesylate.

The enantioselective access to the more widespread uleine alkaloids with a cis $\mathrm{H}_{15}-\mathrm{H}_{20}$ relationship (normal series) required the preparation of a cis-4,5-disubstituted 2-piperidone by stereocontrolled conjugate addition of an appropriate nucleophile to unsaturated lactam 10, avoiding the undesired equilibration to the more stable trans isomers. Taking into account that metalated dithioacetals have been reported to undergo conjugated addition reactions to unsaturated amides and lactams in fair yields, ${ }^{17,18}$ we decided to investigate the introduction of the required indolylmethyl substituent on the 4 position of the piperidine ring of lactam $\mathbf{1 0}$ by conjugate addition of a 2-(2-indolyl)-1,3-dithiane derivative. It should be mentioned that, although much effort has been devoted to identifying the factors governing the regioselectivity

(17) (a) Mpango, G. B.; Mahalanabis, K. K.; Mahdavi-Damghani, Z.; Snieckus, V. Tetrahedron Lett. 1980, 21, 4823. (b) Mpango, G. B.; Snieckus, V. Tetrahedron Lett. 1980, 21, 4827. See also ref 10i,n,o.

(18) For a recent review on 1,3-dithianes in natural product synthesis, see: Yus, M.; Nájera, C.; Foubelo, F. Tetrahedron 2003, 59, 6147. in the addition of sulfur-stabilized anions to enones, ${ }^{19}$ there are few reports concerning the stereoselectivity of such conjugate addition reactions. ${ }^{19 \mathrm{e}}$ For this reason, we became interested in studying the stereochemical outcome of the conjugate addition of a variety of dithioacetals to phenylglycinol-derived unsaturated lactams as a tool for the enantioselective generation of cis or trans 3,4disubstituted piperidine derivatives. To explore the influence on the stereoselectivity of an alkyl substituent next to the electrophilic carbon of the double bond, in our study we used lactams cis-2 and $\mathbf{1 0}$ as substrates, both with a cis 3,8a relative configuration. Moreover, to gain further insight into the factors governing the stereoselectivity of the reaction we also used lactam trans-2, the C-8a diastereomer of cis-2. The results are summarized in Table $1 .{ }^{20}$

The addition of 2-lithio-1,3-dithiane (15-Li) to the diastereomeric unsubstituted lactams trans-2 and cis-2 and the ethyl-substituted lactam $\mathbf{1 0}$ at low temperature $\left(-78{ }^{\circ} \mathrm{C}\right)$, followed by stirring at $0{ }^{\circ} \mathrm{C}$ for $20 \mathrm{~h}$ in $\mathrm{THF}$ in the presence of HMPA, took place with excellent facial selectivity to give the corresponding exo adducts 21a, 25a, and 29a, respectively (entries 1, 6, and 13). Similar results were observed in the addition of $\mathbf{1 5}$-Li to trans-2 in the absence of HMPA (entry 2). However, on raising the temperature to $25{ }^{\circ} \mathrm{C}$ lactam $\mathbf{1 0}$ afforded a nearly equimolecular mixture of isomers $29 \mathbf{a}$ and $\mathbf{2 9 b}$ (entry 14). On the other hand, conjugate addition of the lithium salt of bis(phenylthio)methane (19-Li) to lactam $\mathbf{1 0}$ at $0{ }^{\circ} \mathrm{C}$ took place with low exo stereoselectivity (entry 15), whereas at $25{ }^{\circ} \mathrm{C}$ the endo isomer 30b was the major component of the reaction mixture (entry 16). The above results suggest that the addition of lithium salts $15-\mathrm{Li}$ and $19-\mathrm{Li}$ to 10 is reversible and that, under the same reaction conditions, $19-\mathrm{Li}$ affords a higher ratio of the thermodynamic endo isomer $\mathbf{b}$ (trans relative configuration of the substituents), presumably as a consequence of the higher steric hindrance in the corresponding adduct and the greater anion stability of $19-\mathrm{Li}$ as compared with 15- $\mathrm{Li} .{ }^{21}$

The reaction of 2-lithio-2-phenyl-1,3-dithiane (16-Li) with trans-2 at $0{ }^{\circ} \mathrm{C}$ for $20 \mathrm{~h}$ again led to the corresponding exo isomer 16a (entry 3), although with lower stereoselectivity than when using $15-\mathrm{Li}$, whereas starting from cis-2 an approximately 25:75 mixture of isomers, in which the endo derivative $\mathbf{2 6 \mathbf { b }}$ predominated, was obtained (entry 7). There was a similar result when the reaction of 16 - $\mathrm{Li}$ with $\mathrm{cis}-\mathbf{2}$ was carried out at room temperature (entry 8). However, a reversal in the stereochemical outcome of the reaction was observed when the addition of $\mathbf{1 6}$-Li to cis-2 was performed under kinetic

(19) (a) Ostrowski, P. C.; Kane, V. V. Tetrahedron Lett. 1977, 3549. (b) Ager, D. J.; East, M. B. J. Org. Chem. 1986, 51, 3983. (c) Cohen, T.; Abraham, W. D.; Myers, M. J. Am. Chem. Soc. 1987, 109, 7923. (d) Page, P. C. B.; van Niel, M. B.; Prodger, J. C. Tetrahedron 1989, 45 7643. (e) Sikorski, W. H.; Reich, H. J. J. Am. Chem. Soc. 2001, 123, 6527. (f) Juaristi, E.; Hernández-Rodríguez, M.; López-Ruiz, H.; Aviña, J.; Muñoz-Muñiz, O.; Hayakawa, M.; Seebach, D. Helv. Chim. Acta 2002, 85, 1999 .

(20) For a preliminary account covering part of these results, see: Amat, M.; Pérez, M.; Llor, N.; Bosch, J. Org. Lett. 2002, 4, 2787.

(21) For $\mathrm{p} K$ values of dithioacetals 15, 16, and 19, see: (a) Fraser, R. R.; Bresse, M.; Mansour, T. S. J. Chem. Soc., Chem. Commun. 1983, 620. (b) Xie, L.; Bors, D. A.; Streitwieser, A. J. Org. Chem. 1992, 57, 4986. (c) Xie, L.; Streitwieser, A. J. Org. Chem. 1995, 60, 1339. (d) Alnajjar, M. S.; Zhang, X.-M.; Franz, J. A.; Bordwell, F. G. J. Org. Chem. 1995, 60, 4976. 
TABLE 1. Conjugate Addition of Sulfur-Stabilized Nucleophiles ${ }^{a}$

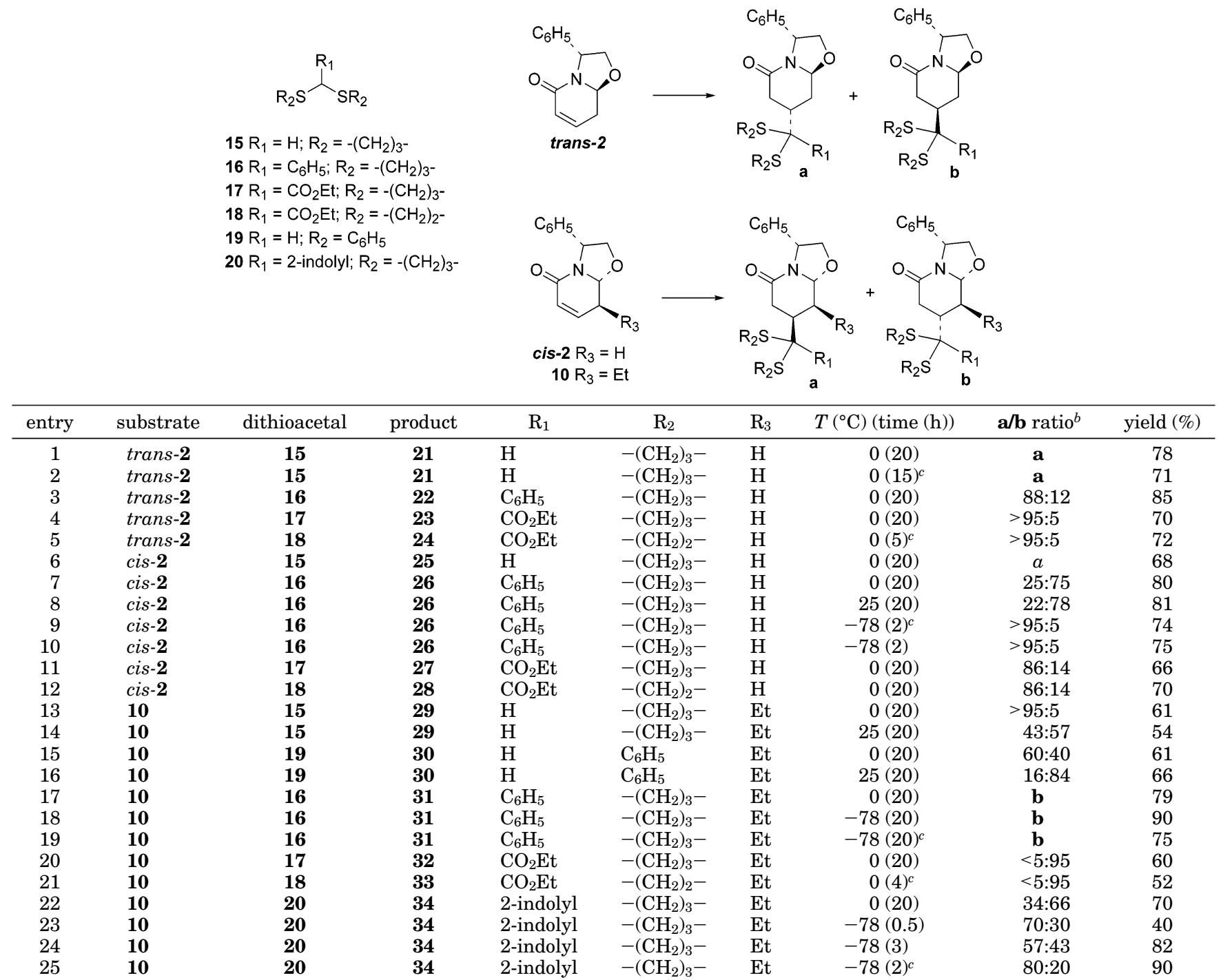

${ }^{a}$ See the general procedure in the Experimental Section. ${ }^{b}$ Determined by ${ }^{1} \mathrm{H}$ NMR and/or after isolation by column chromatography. ${ }^{c}$ In the absence of HMPA.

conditions, that is at low temperature $\left(-78^{\circ} \mathrm{C}\right)$ for a short reaction time $(2 \mathrm{~h})$ both in the absence and in the presence of HMPA (entries 9 and 10). Under these conditions, compound $\mathbf{2 6 a}$, resulting from an exo attack of the nucleophile, was stereoselectively formed. On the other hand, the addition of 16- Li to lactam 10 stereoselectively afforded the thermodynamic endo isomer $\mathbf{3 1 b}$ under a variety of conditions (entries 17-19). These results can be rationalized once again by considering the higher steric hindrance in the adducts resulting from 16-Li and the higher stability of this anion as compared with 15-Li. ${ }^{21}$ In fact, when pure isomers $\mathbf{2 2 a}$ and $\mathbf{2 6 a}$ were stirred in the presence of 4 equiv of 16 - Li at $25^{\circ} \mathrm{C}$, a slow isomerization to the corresponding endo epimers 22b and 26b was observed, thus corroborating the reversibility of the reaction.

We also examined the stereoselectivity in the conjugate addition of sulfur-stabilized enolates $17-\mathrm{Li}$ and $18-\mathrm{Li}$, which whould allow the introduction of an acetate chain at the 4 position of the piperidine ring after desulfurization. The addition of the masked glyoxylate anions 17-Li and 18-Li to the diastereomeric lactams trans-2 and cis-2 at $0{ }^{\circ} \mathrm{C}$ for $20 \mathrm{~h}$ predominantly afforded the kinetic exo isomers 23a, 24a (entries 4 and 5) and 27a, 28a (entries 11 and 12), respectively. ${ }^{16}$ Again the exo stereoselectivity was higher from the unsaturated lactam trans-2 than from cis-2. In sharp contrast, under the same conditions, the conjugate addition of the highly stabilized enolates 17-Li and 18-Li to lactam 10 occurred with almost complete endo facial selectivity, affording the endo isomers 32b and 33b (entries 20 and 21). ${ }^{16}$ The above results evidenced that, as already observed when using indoleacetic ester enolates, under the same reaction conditions the endo/exo ratio using sulfur-stabilized nucleophiles is much higher from the 8-ethyl-substituted lactam 10 than from the deethyl analogue cis-2. In contrast, the related lactams cis-1a and cis-1b, the latter bearing an ethyl substituent at C-8 (see Figure 2), undergo conjugate addition of cuprates with the same exo selectivity. ${ }^{5 a, 7}$

To better understand why the conjugate addition of stabilized nucleophiles to the 8-ethyl-substituted lactam 10 and its deethyl analogue cis-2 takes place with different facial selectivity we first examined the reactivity 
TABLE 2. Electrostatic $\left(E_{\text {ele }}\right)$, Polarization $\left(E_{\text {pol }}\right)$, van der Waals $\left(E_{\mathrm{vW}}\right)$, and Total Interaction $\left(\boldsymbol{E}_{\text {tot }}\right)$ Energy Determined from GMIPp Calculations for the Attack of a Negatively Charged Classical Point Charge to the Two Faces of the Lactam Ring at $\mathrm{C7}^{a}$

\begin{tabular}{lllllr}
\hline lactam & face & $E_{\text {ele }}$ & $E_{\mathrm{pol}}$ & $E_{\mathrm{vW}}$ & $E_{\text {tot }}$ \\
\hline cis-2 $^{b}$ & exo & -4.9 & -12.2 & +2.5 & -14.5 \\
& endo & +1.0 & -11.6 & +2.3 & -8.3 \\
$\mathbf{1 0}$ & exo & -5.2 & -11.7 & +1.1 & -15.9 \\
& endo & +1.7 & -11.3 & +0.8 & -8.9
\end{tabular}

${ }^{a}$ Values are in kcal/mol. ${ }^{b}$ Data taken from ref 5 a.

TABLE 3. Energy Changes for the Formation of the Enolate Adduct ${ }^{a}$

\begin{tabular}{clc}
\hline lactam & face & $\Delta \mathrm{E}$ \\
\hline cis-2 & exo & -2.7 \\
& endo & -6.7 \\
$\mathbf{1 0}$ & exo & +2.6 \\
& endo & -4.6
\end{tabular}

${ }^{a}$ Values are in $\mathrm{kcal} / \mathrm{mol}$.

pattern of these bicyclic lactams from GMIPp calculations $^{22}$ (see the Computational Methods). To this end, we determined the GMIPp interaction energy profile for the approach of a negatively charged classical point particle along the line perpendicular to the six-membered ring passing through carbon 7 . As noted in Table 2, the two faces of the lactam ring have different susceptibility to the attack of a nucleophilic reagent. Thus, the exo attack is found to be energetically more favorable than the endo attack by $6-7 \mathrm{kcal} / \mathrm{mol}$. Moreover, the results in Table 2 also show that such a preference clearly stems from the electrostatic term, and that replacement of the hydrogen atom by an ethyl group has negligible influence on the intrinsic reactivity of lactams cis-2 and $\mathbf{1 0}$.

Table 3 shows the reaction energies corresponding to the formation of the enolate adducts obtained by nucleophilic attack of either a hypothetical methyl anion (a small nucleophile) or the anion derived from dithiolane 18 (a bulky nucleophile) on the two faces of the unsaturated C-7 carbon of cis-2 and 10. For the attack of the methyl anion, the adducts are highly favored (by around $82 \mathrm{kcal} / \mathrm{mol}$ ) compared to the separate reactants, and the energy difference between the enolates formed upon addition on the exo or endo faces is less than $1.5 \mathrm{kcal} /$ mol. However, the energetic stabilization of the enolate adducts is drastically reduced in the case of the bulky anion derived from dithiolane 18. In fact, the addition of this anion on the exo face of the substituted lactam $\mathbf{1 0}$ is even predicted to be energetically disfavored. More importantly, the relative energy of the two enolates is clearly different, the adduct formed upon attack on the endo face being energetically preferred by 4 (cis-2) and 6 (10) $\mathrm{kcal} / \mathrm{mol}$.

Consequently, it can be concluded that even though the intrinsic reactivity of lactams cis-2 and $\mathbf{1 0}$ favors a nucleophilic attack on the exo face owing to a better electrostatic interaction, the steric hindrance associated with the enolate resulting from the approach of a bulky anion to the exo face tends to reverse such a reactivity preference.

Finally, with our synthetic purpose in mind, we undertook the conjugate addition of the dilithium salt of 2-(2-indolyl)-1,3-dithiane (20) to lactam 10. When the reaction was carried out in $\mathrm{THF}-\mathrm{HMPA}$ at $0{ }^{\circ} \mathrm{C}$ for 20 h, a 34:66 mixture of exo and endo isomers, 34a and 34b, respectively, was obtained in good chemical yield $(70 \%)$ (entry 22). Probably as a consequence of the dianionic character of the nucleophile, the equilibration between the desired kinetic exo addition product to the thermodynamic endo adduct (a trans 4,5-disubstituted 2-piperidone) was slower in this case than in the above experiments with 16-Li. As could be expected, the exo stereoselectivity leading to the desired cis isomer 34a was improved (exo/endo 7:3), although the chemical yield was only moderate $(40 \%)$, when the reaction was carried out at lower temperature $\left(-78^{\circ} \mathrm{C}\right)$ for a short time $(30 \mathrm{~min})$ in order to minimize the equilibration process (entry 23 ). Longer reaction times $(3 \mathrm{~h})$ under the same conditions resulted in a higher chemical yield but a lower stereoselectivity (entry 24). However, to our delight, in the absence of HMPA the reaction took place at $-78{ }^{\circ} \mathrm{C}$ in an extraordinarily high yield (90\%) and good stereoselectivity from the synthetic standpoint (exo/endo ratio 4:1; entry 25). After column chromatography the required enantiopure piperidone cis-34a was isolated in $72 \%$ yield.

The stereochemical identity of some adducts obtained in the above conjugate addition reactions was established by desulfurization with nickel boride and comparison of the specific rotation and spectroscopic data of the resulting compounds with those of related lactams of known configuration previously prepared in our laboratory. Thus, desulfurization of $\mathbf{2 1 a}, \mathbf{2 5 a}$, and $\mathbf{2 9 a} / \mathbf{3 0 a}$ afforded 35, 37, and 39, respectively, which had previously been prepared $^{5 a, 7}$ by conjugate addition reactions of methyl organocuprates to lactams trans-1 and cis-1a,b followed by debenzyloxycarbonylation. On the other hand, desulfurization of $\mathbf{2 9 b}$ and $\mathbf{3 0 b}$ gave $\mathbf{4 0}$, the C-7 epimer of 39. Treatment of compounds $\mathbf{2 4 a}$ and $\mathbf{2 8 \mathbf { a }}$ with nickel boride afforded $\mathbf{3 6}$ and $\mathbf{3 8}$, respectively, which are C-7 diastereomers of bicyclic lactams obtained by cyclocondensation of diethyl 3-(2-oxoethyl)glutarate and $(R)$-phenylglycinol. ${ }^{5 b}$ Similarly, 33b was converted to lactam 42, which had previously been obtained by cyclocondensation of a racemic aldehyde diester and $(R)$-phenylglycinol. ${ }^{5 b}$ Finally, the configuration of $\mathbf{2 6 a}, \mathbf{2 6 b}$, and $\mathbf{3 1 b}$ was unambiguously established by X-ray crystallography.

The synthetic usefulness of the above chiral substituted lactams is illustrated by their conversion to enantiopure trans-3,4-disubstituted piperidines (Scheme 6). Thus, desulfurization of $\mathbf{3 1} \mathbf{b}$ followed by lactam reduction with simultaneous reductive ring opening of the oxazolidine present in 41 afforded piperidine 43, whose debenzylation in the presence of (Boc) $)_{2} \mathrm{O}$ gave the trans-4-benzyl-3ethylpiperidine derivative 44. On the other hand, lactam 42 was converted to valuable intermediates for the synthesis of indolo[2,3-a]- and benzo[a]quinolizidine alkaloids. ${ }^{23}$ Thus, treatment of $\mathbf{4 2}$ with borane brought about both the chemoselective reduction of the lactam carbonyl group and the reductive opening of the oxazolidine ring affording 4-piperidineacetate 45, whereas

(22) (a) Luque, F J · Orozco, M. J Comput Chem 1998, 19, 866. (b) Orozco, M.; Luque, F. J. In Molecular Electrostatic Potentials: Concepts and Applications; Murray, J. S., Sen, K., Eds.; Elsevier: Amsterdam, 1996; pp 181-218.

(23) For reviews, see: (a) Fujii, T.; Ohba, M. Heterocycles 1988, 27 1009. (b) Fujii, T.; Ohba, M. Heterocycles 1998, 47, 525. 


\section{SCHEME 6. Synthesis of Enantiopure trans-3,4-Disubstituted Piperidines}

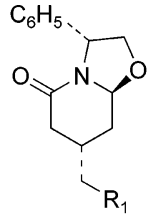

$35 \mathrm{R}_{1}=\mathrm{H}$ $36 \mathrm{R}_{1}=\mathrm{CO}_{2} \mathrm{Et}$

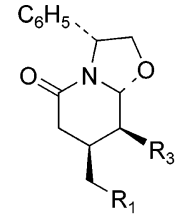

$37 \mathrm{R}_{1}=\mathrm{H} ; \mathrm{R}_{3}=\mathrm{H}$ $38 \mathrm{R}_{1}=\mathrm{CO}_{2} \mathrm{Et} ; \mathrm{R}_{3}=\mathrm{H}$ $39 \mathrm{R}_{1}=\mathrm{H} ; \mathrm{R}_{3}=\mathrm{Et}$

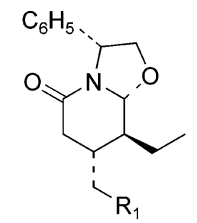

$40 \mathrm{R}_{1}=\mathrm{H}$ $41 \mathrm{R}_{1}=\mathrm{C}_{6} \mathrm{H}_{5}$ $42 \mathrm{R}_{1}=\mathrm{CO}_{2} \mathrm{Et}$
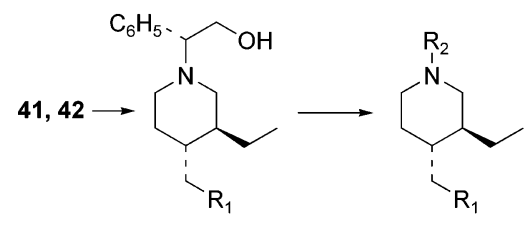

$43 \mathrm{R}_{1}=\mathrm{C}_{6} \mathrm{H}_{5}$ $45 \mathrm{R}_{1}=\mathrm{CO}_{2} \mathrm{Et}$ $47 \mathrm{R}_{1}=\mathrm{CH}_{2} \mathrm{OH}$

$44 \mathrm{R}_{1}=\mathrm{C}_{6} \mathrm{H}_{5} ; \mathrm{R}_{2}=\mathrm{Boc}$ $46 \mathrm{R}_{1}=\mathrm{CO}_{2} \mathrm{Et} ; \mathrm{R}_{2}=\mathrm{H}$ $48 \mathrm{R}_{1}=\mathrm{CH}_{2} \mathrm{OH} ; \mathrm{R}_{2}=\mathrm{H}$

49 reduction of $\mathbf{4 2}$ with alane caused the additional reduction of the ester group yielding 4-piperidineethanol 47. Debenzylation of $\mathbf{4 5}$ and $\mathbf{4 7}$ by catalytic hydrogenation gave trans-3-ethyl-4-piperidineacetate 46 and trans-3ethyl-4-piperidineethanol 48, respectively. Alternatively, hydrogenolysis of the $\mathrm{C}-\mathrm{N}$ bond of $\mathbf{4 2}$ with $\mathrm{Ca}$ in liquid $\mathrm{NH}_{3}$, followed by treatment of the resulting oxylactams with $\mathrm{Et}_{3} \mathrm{SiH}$ in THF afforded lactam 49.

Finally, conversion of the cis-substituted lactam 34a into the target tetracyclic alkaloids of the uleine group required, as the key steps, the closure of the carbocyclic ring and the removal of the chiral inductor. Treatment of $34 \mathbf{a}$ with $\mathrm{TiCl}_{4}$ under several reaction conditions afforded in poor yields $(\sim 20 \%)$ tetracyclic keto lactam 51 resulting from both deprotection of the dithioacetal function and intramolecular amidoalkylation (Scheme 7). A similar $\mathrm{TiCl}_{4}$-promoted cyclization of $\mathbf{5 0}$, prepared by desulfurization of $\mathbf{3 4 a}$, gave tetracycle 52, again in low yield $(\sim 20 \%)$. For this reason we decided to first remove the chiral inductor. This was accomplished by treatment of 34a with sodium in liquid ammonia, which brought about the reductive desulfurization and cleavage of the benzylic $\mathrm{C}-\mathrm{N}$ bond to give an intermediate 6-hydroxylactam, which, without further purification, was cyclized with $\mathrm{TiCl}_{4}$ to give the tetracyclic lactam 53 in $35 \%$ overall yield. Minor amounts $(6 \%)$ of the regioisomer 54, resulting from cyclization on the indole nitrogen, were also formed. ${ }^{24}$ Finally, borane reduction of the lactam carbonyl group of $\mathbf{5 3}$ followed by treatment of the resulting secondary amine with benzyl chloroformate gave $(40 \%$ overall yield) carbamate 55, which had previously been converted $^{4 a}$ into the alkaloids (+)-dasycarpidone and $(+)$-uleine. Taking into account previous correlations, ${ }^{25}$ the above synthesis also represents a formal synthesis of nordasycarpidone, (-)-dasycarpidol, and (-)-17-hydroxydihydrouleine.

In conclusion, conjugate addition reactions of indoleacetic ester enolates and sulfur-stabilized nucleophiles

(24) For a related cyclization, see ref $10 \mathrm{n}$.

(25) (a) Joule, J. A.; Ohashi, M.; Gilbert, B.; Djerasi, C. Tetrahedron 1965, 21, 1717. (b) Gràcia, J.; Casamitjana, N.; Bonjoch, J.; Bosch, J. J. Org. Chem. 1994, 59, 3939 .

\section{SCHEME 7. Enantioselective Formal Synthesis of Uleine Alkaloids}

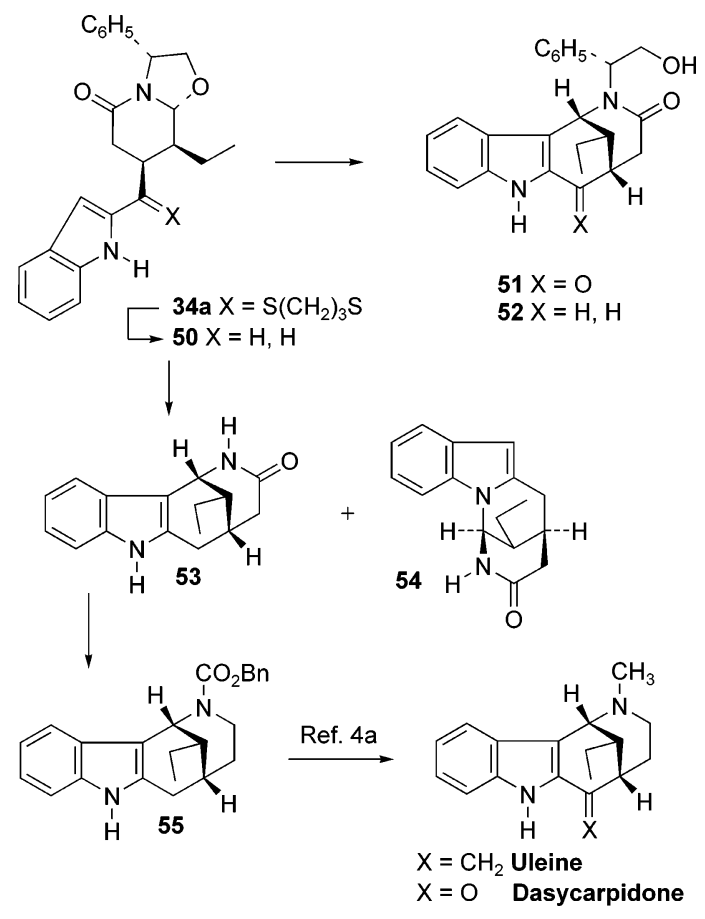

to phenylglycinol-derived unsaturated $\delta$-lactams allow the stereocontrolled formation of $\mathrm{C}-\mathrm{C}$ bonds at the piperidine 4-position. Some factors governing the stereoselectivity of the process, namely the nature of the nuclophile, the configuration of the stereocenter at the angular position (C-8a), and the presence or absence of a $\gamma$-substituent, have been identified. By choosing the appropriate indole-containing nucleophile, the above methodology opens short synthetic routes for the enantioselective construction of the bridged tetracyclic system of uleine alkaloids either in the normal or 20-epi series. The availability of both enantiomers of phenylglycinol allows the preparation, in each particular case, of 4-substituted derivatives in both enantiomeric series.

\section{Experimental Section}

$(3 R, 8 \mathrm{aS})-5$-Oxo-3-phenyl-2,3,8,8a-tetrahydro-5H-oxazolo[3,2-a]pyridine $($ trans-2). Methyl phenylsulfinate $(1.29 \mathrm{~g}$, $8.29 \mathrm{mmol})$ and $\mathrm{KH}(1.0 \mathrm{~g}, 20 \mathrm{wt} \%$ dispersion in mineral oil, $25 \mathrm{mmol})$ were added to a solution of (3R,8aS)-5-oxo-3-phenyl2,3,6,7,8,8a-hexahydro-5H-oxazolo[3,2-a]pyridine ${ }^{5 a}$ (950 mg, $4.37 \mathrm{mmol})$ in THF (15 mL). The suspension was heated at reflux for $1.5 \mathrm{~h}$ and concentrated. The resulting residue was taken up in $0.5 \mathrm{M}$ aqueous $\mathrm{H}_{3} \mathrm{PO}_{4}$ and extracted with $\mathrm{CH}_{2} \mathrm{Cl}_{2}$. The combined organic extracts were dried and concentrated, and the resulting residue was washed with hexane and chromatographed $\left(\mathrm{CHCl}_{3}\right)$ to give $(\mathbf{3 R}, \mathbf{8 a S})-5$-oxo-3-phenyl6-(phenylsulfinyl)- $2,3,6,7,8,8 \mathrm{a}$-hexahydro- $5 \mathrm{H}$-oxazolo $[3,2-$ $\boldsymbol{a}$ ]pyridine $(1.48 \mathrm{~g}, 95 \%)$ as a mixture of isomers: ${ }^{1} \mathrm{H}$ NMR (300 MHz, selected resonances) $\delta 3.46$ (masked s, $1 \mathrm{H}$ ), 3.48 (dd, $J=10.6,7.6 \mathrm{~Hz}, 1 \mathrm{H}), 3.71$ (t, $J=8.5 \mathrm{~Hz}, 1 \mathrm{H}$ ), 3.84 (t, $J=8.5 \mathrm{~Hz}, 1 \mathrm{H}), 4.54(\mathrm{~m}, 2 \mathrm{H}), 5.04(\mathrm{~m}, 2 \mathrm{H}), 5.27(\mathrm{t}, J=8.0$ $\mathrm{Hz}, 1 \mathrm{H}), 5.33(\mathrm{t}, J=8.0 \mathrm{~Hz}, 1 \mathrm{H}) ;{ }^{13} \mathrm{C} \mathrm{NMR}(75.4 \mathrm{MHz}$, selected resonances) $\delta 12.4\left(\mathrm{CH}_{2}\right), 27.1\left(\mathrm{CH}_{2}\right), 58.9(\mathrm{CH}), 65.8$ $(\mathrm{CH}), 72.9\left(\mathrm{CH}_{2}\right), 88.3(\mathrm{CH}), 164.0(\mathrm{C}) . \mathrm{Na}_{2} \mathrm{CO}_{3}(2.69 \mathrm{~g}, 25.3$ $\mathrm{mmol}$ ) was added to a solution of the $\beta$-keto sulfoxide (1.53 g, $4.5 \mathrm{mmol})$ in toluene $(54 \mathrm{~mL})$, and the mixture was heated at reflux for $7 \mathrm{~h}$, filtered through Celite, and concentrated. The resulting oil was chromatographed (7:3 EtOAc-hexane) to 
afford trans-2 (820 mg, 89\%): IR (KBr) 1660, $1611 \mathrm{~cm}^{-1} ;{ }^{1} \mathrm{H}$ NMR $(300 \mathrm{MHz}) \delta 2.48$ (dddd, $J=17.4,10.2,3.2,2.3 \mathrm{~Hz}, 1$ H), 2.80 (dddd, $J=17.4,6.0,6.0,0.7 \mathrm{~Hz}, 1 \mathrm{H}$ ), 3.86 (dd, $J=$ $8.8,7.0 \mathrm{~Hz}, 1 \mathrm{H}), 4.49(\mathrm{dd}, J=8.8,7.0 \mathrm{~Hz}, 1 \mathrm{H}), 5.25(\mathrm{t}, J=$ $7.0 \mathrm{~Hz}, 1 \mathrm{H}), 5.42(\mathrm{dd}, J=10.2,6.0 \mathrm{~Hz}, 1 \mathrm{H}), 5.99(\mathrm{ddd}, J=$ $9.9,3.2,0.7 \mathrm{~Hz}, 1 \mathrm{H}$ ), 6.48 (ddd, $J=9.9,6.0,2.3 \mathrm{~Hz}, 1 \mathrm{H}$ ), 7.22-7.40 (m, 5 H); ${ }^{13} \mathrm{C} \mathrm{NMR}(75.4 \mathrm{MHz}) \delta 29.9\left(\mathrm{CH}_{2}\right), 57.9$ $(\mathrm{CH}), 73.0\left(\mathrm{CH}_{2}\right), 86.7(\mathrm{CH}), 125.4(\mathrm{CH}), 125.9(\mathrm{CH}), 128.7$ (CH), $127.5(\mathrm{CH}), 134.8(\mathrm{CH}), 139.2(\mathrm{C}), 160.7(\mathrm{C})$; mp 121$122{ }^{\circ} \mathrm{C}\left(\mathrm{Et}_{2} \mathrm{O}-\right.$ hexane $) ;[\alpha]^{22} \mathrm{D}+50.5(c 1.0, \mathrm{EtOH})$. Anal. Calcd for $\mathrm{C}_{13} \mathrm{H}_{13} \mathrm{NO}_{2}$ : C, 72.54; H, 6.09; N, 6.51. Found: C, 72.56; $\mathrm{H}, 6.08 ; \mathrm{N}, 6.57$.

$(3 R, 8 \mathrm{a} R)-5-0 x o-3-p h e n y l-2,3,8,8 \mathrm{a}-$ tetrahydro- $5 H$-oxazolo[3,2-a]pyridine (cis-2). Operating as described above, from $(3 R, 8 \mathrm{a} R)$-5-oxo-3-phenyl-2,3,6,7,8,8a-hexahydro-5H-oxazolo$[3,2-a]$ pyridine $^{5 a}(300 \mathrm{mg}, 1.4 \mathrm{mmol})$, THF $(10 \mathrm{~mL})$, methyl phenylsulfinate $(437 \mathrm{mg}, 2.8 \mathrm{mmol})$, and $\mathrm{KH}(840 \mathrm{mg}, 20 \mathrm{wt}$ $\%$ dispersion in mineral oil, $21 \mathrm{mmol})$ was obtained $(\mathbf{3 R}, \mathbf{8 a R})$ 5-oxo-3-phenyl-6-(phenylsulfinyl)-2,3,6,7,8,8a-hexahydro$\mathbf{5 H}$-oxazolo[3,2-a]pyridine $(487 \mathrm{mg}, 97 \%)$ as a mixture of isomers: IR (film) $1661 \mathrm{~cm}^{-1} ;{ }^{1} \mathrm{H} \mathrm{NMR}(300 \mathrm{MHz}$, selected resonances for two isomers) $\delta 3.29(\mathrm{dd}, J=6.6,0.9 \mathrm{~Hz}, 1 \mathrm{H})$, 3.35 (dd, $J=10.5,7.8 \mathrm{~Hz}, 1 \mathrm{H}), 4.05(2 \mathrm{dd}, J=9.0,2.1 \mathrm{~Hz}, 2$ $\mathrm{H}), 4.18(2 \mathrm{dd}, J=9.0,6.9 \mathrm{~Hz}, 2 \mathrm{H}), 4.88(\mathrm{td}, J=9.9,3.0 \mathrm{~Hz}$, $2 \mathrm{H}), 5.00(\mathrm{~d}, J=6.9 \mathrm{~Hz}, 2 \mathrm{H}, \mathrm{H}-3) ;{ }^{13} \mathrm{C} \mathrm{NMR}(75.4 \mathrm{MHz}$, selected resonances) $\delta 12.8\left(\mathrm{CH}_{2}\right), 16.9\left(\mathrm{CH}_{2}\right), 26.5\left(\mathrm{CH}_{2}\right), 27.2$ $\left(\mathrm{CH}_{2}\right), 59.2(\mathrm{CH}), 59.5(\mathrm{CH}), 65.3(\mathrm{CH}), 65.4(\mathrm{CH}), 73.7\left(\mathrm{CH}_{2}\right)$, $73.8\left(\mathrm{CH}_{2}\right), 88.1(\mathrm{CH}), 88.8(\mathrm{CH}), 162.0(\mathrm{C}), 162.2(\mathrm{C})$. From the $\beta$-keto sulfoxide $(487 \mathrm{mg}, 136 \mathrm{mmol})$, toluene $(15 \mathrm{~mL})$, and $\mathrm{Na}_{2} \mathrm{CO}_{3}(804 \mathrm{mg})$ was obtained cis-2 (260 mg, 89\%) after flash chromatography (2:1 EtOAc- $\mathrm{CHCl}_{3}$ ): IR (film) 1670, 1606 $\mathrm{cm}^{-1} ;{ }^{1} \mathrm{H}$ NMR $(300 \mathrm{MHz}) \delta 2.60$ (dddd, $J=17.2,11.7,3.3$, $2.1 \mathrm{~Hz}, 1 \mathrm{H}$ ), 2.82 (dddd, $J=17.1,6.6,4.5,0.9 \mathrm{~Hz}, 1 \mathrm{H}$ ), 4.10 $(\mathrm{dd}, J=9.0,1.5 \mathrm{~Hz}, 1 \mathrm{H}), 4.20(\mathrm{dd}, J=9.0,6.9 \mathrm{~Hz}, 1 \mathrm{H}), 5.03$ (dd, $J=6.9,1.5 \mathrm{~Hz}, 1 \mathrm{H}), 5.11(\mathrm{dd}, J=11.7,4.5 \mathrm{~Hz}, 1 \mathrm{H})$, $5.94(\mathrm{ddd}, J=9.9,3.0,0.9 \mathrm{~Hz}, 1 \mathrm{H}), 6.52(\mathrm{dd}, J=9.9,2.1 \mathrm{~Hz}$, $1 \mathrm{H}), 7.10-7.35(\mathrm{~m}, 5 \mathrm{H}) ;{ }^{13} \mathrm{C}$ NMR $(75.4 \mathrm{MHz}) \delta 29.9\left(\mathrm{CH}_{2}\right)$, $57.3(\mathrm{CH}), 74.0\left(\mathrm{CH}_{2}\right), 86.8(\mathrm{CH}), 126.1(\mathrm{CH}), 126.2(\mathrm{CH}), 128.3$ (CH), $127.3(\mathrm{CH}), 135.9(\mathrm{CH}), 140.7(\mathrm{C}), 161.1(\mathrm{C}) ; \mathrm{mp} 45-50$ ${ }^{\circ} \mathrm{C} ;[\alpha]^{22} \mathrm{D}+5.2\left(\right.$ c 1.0, $\left.\mathrm{CHCl}_{3}\right)$.

Methyl (3R,7S,8aS)- $\alpha$-(1-Methyl-2-indolyl)-5-oxo-3-phenyl-2,3,6,7,8,8a-hexahydro-5H-oxazolo[3,2-a]pyridine-7acetate (4a). LDA was prepared by addition of diisopropylamine $(0.31 \mathrm{~mL}, 2.22 \mathrm{mmol})$ to a cooled $\left(-78^{\circ} \mathrm{C}\right)$ solution of $n$-BuLi (1.3 mL of a $1.6 \mathrm{M}$ solution in hexanes, $2.08 \mathrm{mmol})$ in THF ( $4 \mathrm{~mL}$ ). The mixture was stirred at $-78^{\circ} \mathrm{C}$ for $5 \mathrm{~min}$ and at $0{ }^{\circ} \mathrm{C}$ for $5 \mathrm{~min}$, and cooled at $-78{ }^{\circ} \mathrm{C}$. Then, a solution of ester $\mathbf{3 a}^{12}$ (422 mg, $\left.2.08 \mathrm{mmol}\right)$ in THF $(30 \mathrm{~mL})$ was added dropwise, and the mixture was stirred at $-78{ }^{\circ} \mathrm{C}$ for $30 \mathrm{~min}$. A solution of trans-2 $(300 \mathrm{mg}, 1.39 \mathrm{mmol})$ in THF $(5 \mathrm{~mL})$ was added via cannula, and the mixture was stirred at $0{ }^{\circ} \mathrm{C}$ for 4 h, poured into saturated aqueous $\mathrm{NaHCO}_{3}$, and extracted with EtOAc. The combined organic extracts were dried and concentrated to give an oil. Flash chromatography $\left(\mathrm{Et}_{2} \mathrm{O}\right)$ afforded $230 \mathrm{mg}$ of $(\alpha S)-\mathbf{4 a}$ and $140 \mathrm{mg}$ of $(\alpha R)-\mathbf{4 a}$ (overall yield $64 \%$ ). $(\alpha S)-4 a$ (lower $\left.R_{f}\right)$ : IR $(\mathrm{NaCl}) 1737,1663 \mathrm{~cm}^{-1} ;{ }^{1} \mathrm{H}$ NMR (300 MHz) $\delta 1.97(\mathrm{dt}, J=14.0,5.0 \mathrm{~Hz}, 1 \mathrm{H}, \mathrm{H}-8), 2.06$ (ddd, $J=$ 14.0, 7.5, 5.2 Hz, $1 \mathrm{H}, \mathrm{H}-8), 2.43(\mathrm{dd}, J=17.0,7.0 \mathrm{~Hz}, 1 \mathrm{H}$, H-6), 2.72 (ddd, $J=17.0,5.0,0.8 \mathrm{~Hz}, 1 \mathrm{H}, \mathrm{H}-6), 3.07$ (m, $1 \mathrm{H}$, $\mathrm{H}-7), 3.67$ (s, $\left.3 \mathrm{H}, \mathrm{CH}_{3} \mathrm{~N}\right), 3.72(\mathrm{dd}, J=8.5,7.0 \mathrm{~Hz}, 1 \mathrm{H}, \mathrm{H}-2)$, $3.77\left(\mathrm{~s}, 3 \mathrm{H}, \mathrm{CH}_{3} \mathrm{O}\right), 3.82\left(\mathrm{~d}, J=11.0 \mathrm{~Hz}, 1 \mathrm{H}, \mathrm{CHCO}_{2} \mathrm{Me}\right)$, $4.45\left(\mathrm{t}_{\mathrm{ap}}, J=8.5 \mathrm{~Hz}, 1 \mathrm{H}, \mathrm{H}-2\right), 4.83\left(\mathrm{t}_{\mathrm{ap}}, J=5.3 \mathrm{~Hz}, 1 \mathrm{H}\right.$, $\mathrm{H}-8 \mathrm{a}), 5.41\left(\mathrm{t}_{\mathrm{ap}}, J=7.5 \mathrm{~Hz}, 1 \mathrm{H}, \mathrm{H}-3\right), 6.52$ (s, $1 \mathrm{H}, \mathrm{H}-3$ ind), $7.12(\mathrm{tm}, J=7.8 \mathrm{~Hz}, 1 \mathrm{H}, \mathrm{H}-5 \mathrm{ind}), 7.23(\mathrm{tm}, J=7.5 \mathrm{~Hz}, 1 \mathrm{H}$, H-6 ind ), 7.24-7.42 (m, $6 \mathrm{H}, \mathrm{ArH}), 7.57(\mathrm{dm}, J=7.8 \mathrm{~Hz}, 1 \mathrm{H}$, $\mathrm{H}-4$ ind); ${ }^{13} \mathrm{C}$ NMR $(75.4 \mathrm{MHz}) \delta 30.0\left(\mathrm{CH}_{3} \mathrm{~N}\right), 30.0(\mathrm{C}-8) ; 31.3$ (C-7), $37.0(\mathrm{C}-6), 47.2\left(\mathrm{CHCO}_{2} \mathrm{Me}\right), 52.6\left(\mathrm{CH}_{3} \mathrm{O}\right), 58.0(\mathrm{C}-3), 71.7$ (C-2), 85.7 (C-8a), 101.5 (C-3 ind), 109.3 (C-7 ind), 119.9 (C-4 ind), 120.6 (C-5 ind), 121.9 (C-6 ind), 125.8, 128.9 (C-o, $m$ ), 126.0 (C-3a ind), 127.7 (C-p), 134.2 (C-2 ind), 137.5 (C-i), 139.6 (C-7a ind), 168.7 (NCO), 171.2 (COO); mp $65-69{ }^{\circ} \mathrm{C}\left(\mathrm{Et}_{2} \mathrm{O}\right)$; $[\alpha]^{22}+53.8\left(c\right.$ 0.5, $\left.\mathrm{CHCl}_{3}\right)$. Anal. Calcd for $\mathrm{C}_{25} \mathrm{H}_{26} \mathrm{~N}_{2} \mathrm{O}_{4}: \mathrm{C}$,
71.75; H, 6.26; N, 6.69. Found: C, 71.49; H, 6.63; N, 6.29. ( $\alpha R)-$ 4a (higher $\left.R_{f}\right)$ : IR (film) $1734,1661 \mathrm{~cm}^{-1} ;{ }^{1} \mathrm{H}$ NMR $\left(\mathrm{CDCl}_{3}\right.$, $300 \mathrm{MHz}) \delta 2.12$ (ddd, $J=14.0,6.0,4.5 \mathrm{~Hz}, 1 \mathrm{H}), 2.23$ (dd, $J$ $=17.3,6.0 \mathrm{~Hz}, 1 \mathrm{H}), 2.31(\mathrm{~m}, 1 \mathrm{H}), 2.48(\mathrm{dd}, J=17.3,5.2 \mathrm{~Hz}$, $1 \mathrm{H}), 2.98(\mathrm{~m}, 1 \mathrm{H}), 3.69(\mathrm{~s}, 3 \mathrm{H}), 3.72(\mathrm{~s}, 3 \mathrm{H}), 3.80(\mathrm{dd}, J=$ 8.7, $7.5 \mathrm{~Hz}, 1 \mathrm{H}), 3.87(\mathrm{~d}, J=11.0 \mathrm{~Hz}, 1 \mathrm{H}), 4.52\left(\mathrm{t}_{\mathrm{ap}}, J=8.3\right.$ $\mathrm{Hz}, 1 \mathrm{H}), 5.14\left(\mathrm{t}_{\mathrm{ap}}, J=5.5 \mathrm{~Hz}, 1 \mathrm{H}\right), 5.37\left(\mathrm{t}_{\mathrm{ap}}, J=8.0 \mathrm{~Hz}, 1 \mathrm{H}\right)$, $6.52(\mathrm{~s}, 1 \mathrm{H}), 7.10(\mathrm{ddd}, J=7.8,7.0,1.2 \mathrm{~Hz}, 1 \mathrm{H}), 7.20(\mathrm{tm}, J$ $=7.0 \mathrm{~Hz}, 1 \mathrm{H}), 7.25-7.40(\mathrm{~m}, 6 \mathrm{H}), 7.56(\mathrm{dm}, J=7.8 \mathrm{~Hz}, 1$ $\mathrm{H}) ;{ }^{13} \mathrm{C}$ NMR $(75.4 \mathrm{MHz}) \delta 29.8\left(\mathrm{CH}_{3}\right), 31.0\left(\mathrm{CH}_{2}\right), 32.7(\mathrm{CH})$, $35.4\left(\mathrm{CH}_{2}\right), 46.6(\mathrm{CH}), 52.7\left(\mathrm{CH}_{3}\right), 58.1(\mathrm{CH}), 72.0\left(\mathrm{CH}_{2}\right), 86.0$ $(\mathrm{CH}), 101.0(\mathrm{CH}), 109.3(\mathrm{CH}), 119.9(\mathrm{CH}), 120.5(\mathrm{CH}), 121.9$ $(\mathrm{CH}), 125.9(\mathrm{CH}), 128.9(\mathrm{CH}), 125.9(\mathrm{C}), 127.7(\mathrm{CH}), 134.6$ (CH), 137.4 (C), 139.7 (C), 168.5 (C), $171.3(\mathrm{C}) ; \mathrm{mp}$ 240-245 ${ }^{\circ} \mathrm{C}\left(\mathrm{Et}_{2} \mathrm{O}\right) ;[\alpha]^{22}{ }_{\mathrm{D}}-123.6$ (c $\left.0.5, \mathrm{CHCl}_{3}\right)$. Anal. Calcd for $\mathrm{C}_{25} \mathrm{H}_{26} \mathrm{~N}_{2} \mathrm{O}_{4} \cdot 1 \mathrm{H}_{2} \mathrm{O}:$ C, 68.79; H, 6.46; N, 6.41. Found: C, 68.70; $\mathrm{H}, 6.18 ; \mathrm{N}, 6.40$.

(1S,5S,6S)-2-[(1R)-2-Hydroxy-1-phenylethyl]-6-(methoxycarbonyl)-7-methyl-3-oxo-1,2,3,4,5,6-hexahydro-1,5methanoazocino[4,3-b] indole $[(\mathbf{1 6 S})-5 \mathbf{a}]$. $\mathrm{TiCl}_{4}(90 \mu \mathrm{L}, 0.82$ mmol) was added to a cooled $\left(0{ }^{\circ} \mathrm{C}\right)$ solution of $(\alpha S)-\mathbf{4 a}(230$ $\mathrm{mg}, 0.55 \mathrm{mmol})$ in $\mathrm{CH}_{2} \mathrm{Cl}_{2}(2 \mathrm{~mL})$, and the resulting mixture was stirred for $2 \mathrm{~h}$, poured into saturated aqueous $\mathrm{NaHCO}_{3}$, and extracted with $\mathrm{CH}_{2} \mathrm{Cl}_{2}$. The combined organic extracts were dried and concentrated, and the resulting residue was chromatographed (EtOAc) to give (16S)-5a (100 mg, 44\%) and trace amounts of (16R)-5a and starting material. (16S)-5a: IR (KBr) 1731, $1621 \mathrm{~cm}^{-1} ;{ }^{1} \mathrm{H}$ NMR $(300 \mathrm{MHz}) \delta 2.12(\mathrm{dt}, J=$ $13.2,3.3 \mathrm{~Hz}, 1 \mathrm{H}), 2.28(\mathrm{dm}, J=13.2 \mathrm{~Hz}, 1 \mathrm{H}), 2.46(\mathrm{~d}, J=$ $18.0 \mathrm{~Hz}, 1 \mathrm{H}), 3.09(\mathrm{dm}, J=10.0 \mathrm{~Hz}, 1 \mathrm{H}), 3.17(\mathrm{dd}, J=18.0$, $9.1 \mathrm{~Hz}, 1 \mathrm{H}), 3.62(\mathrm{~s}, 3 \mathrm{H}), 3.72(\mathrm{~s}, 3 \mathrm{H}), 3.81(\mathrm{~d}, J=1.4 \mathrm{~Hz}, 1$ $\mathrm{H}$ ), 3.86 (ddd, $J=14.5,4.3,2.6 \mathrm{~Hz}, 1 \mathrm{H}$ ), 4.05 (ddd, $J=14.5$, 9.4, $6.3 \mathrm{~Hz}, 1 \mathrm{H}), 4.63$ (br t, $J=2.7 \mathrm{~Hz}, 1 \mathrm{H}), 4.86$ (dd, $J=9.4$, $4.3 \mathrm{~Hz}, 1 \mathrm{H}), 4.92(\mathrm{dd}, J=6.3,2.6 \mathrm{~Hz}, 1 \mathrm{H}), 7.10-7.50(\mathrm{~m}, 9$ $\mathrm{H}) ;{ }^{13} \mathrm{C} \mathrm{NMR}(75.4 \mathrm{MHz}) \delta 29.1\left(\mathrm{CH}_{2}\right), 29.6(\mathrm{CH}), 30.2\left(\mathrm{CH}_{3}\right)$, $39.2\left(\mathrm{CH}_{2}\right), 46.9(\mathrm{CH}), 51.2(\mathrm{CH}), 52.6\left(\mathrm{CH}_{3}\right), 64.6\left(\mathrm{CH}_{2}\right), 70.3$ $(\mathrm{CH}), 109.5(\mathrm{CH}), 112.6(\mathrm{C}), 118.3(\mathrm{CH}), 120.1(\mathrm{CH}), 122.1$ $(\mathrm{CH}), 124.6(\mathrm{C}), 127.4(\mathrm{CH}), 127.7(\mathrm{CH}), 128.7(\mathrm{CH}), 130.3(\mathrm{C})$, 137.5 (C), 137.6 (C), 170.9 (C), 171.5 (C); mp 205-208 ${ }^{\circ} \mathrm{C}$ $\left(\mathrm{Et}_{2} \mathrm{O}-\mathrm{CH}_{2} \mathrm{Cl}_{2}\right) ;[\alpha]^{22}{ }_{\mathrm{D}}-6.1\left(c 1.0, \mathrm{CH}_{2} \mathrm{Cl}_{2}\right)$. Anal. Calcd for $\mathrm{C}_{25} \mathrm{H}_{26} \mathrm{~N}_{2} \mathrm{O}_{4}$ : C, 71.75; H, 6.26; N, 6.69. Found: C, 71.66; H, $6.27 ; \mathrm{N}, 6.62$.

(1S,5S,6R)-2-[(1R)-2-Hydroxy-1-phenylethyl]-6-(methoxycarbonyl)-7-methyl-3-oxo-1,2,3,4,5,6-hexahydro-1,5methanoazocino[4,3-b]indole $[(\mathbf{1 6 R})-5 a]$. Operating as described above, starting from $(\alpha R)-4 a(50 \mathrm{mg}, 0.12 \mathrm{mmol})$ in $\mathrm{CH}_{2} \mathrm{Cl}_{2}(4 \mathrm{~mL})$ and $\mathrm{TiCl}_{4},(20 \mu \mathrm{L}, 0.18 \mathrm{mmol})$ at $\mathrm{rt}$ for $5 \mathrm{~h}$, pure (16R)-5a (25 mg, 50\%), trace amounts of (16S)-5a, and starting material $(10 \mathrm{mg})$ were obtained after flash chromatography (EtOAc). (16R)-5a: IR (film) 1733, $1620 \mathrm{~cm}^{-1} ;{ }^{1} \mathrm{H}$ NMR (300 $\mathrm{MHz}) \delta 2.00(\mathrm{~m}, 1 \mathrm{H}), 2.30(\mathrm{dt}, J=13.2,3.3 \mathrm{~Hz}, 1 \mathrm{H}), 2.54(\mathrm{~d}$, $J=19.0 \mathrm{~Hz}, 1 \mathrm{H}), 2.87$ (dd, $J=19.0,8.2 \mathrm{~Hz}, 1 \mathrm{H}), 3.15$ (m, 1 $\mathrm{H}), 3.57(\mathrm{~s}, 3 \mathrm{H}), 3.85(\mathrm{~s}, 3 \mathrm{H}), 3.90$ (ddd, $J=13.5,4.7,2.9 \mathrm{~Hz}$, $1 \mathrm{H}), 4.03$ (ddd, $J=13.5,9.3,6.4 \mathrm{~Hz}, 1 \mathrm{H}), 4.18(\mathrm{~d}, J=$ $6.0 \mathrm{~Hz}, 1 \mathrm{H}), 4.58(\mathrm{~m}, 1 \mathrm{H}), 4.78(\mathrm{~m}, 1 \mathrm{H}), 4.85(\mathrm{dd}, J=6.1$, $2.4 \mathrm{~Hz}, 1 \mathrm{H}), 7.10-7.50(\mathrm{~m}, 9 \mathrm{H}) ;{ }^{13} \mathrm{C} \mathrm{NMR}(75.4 \mathrm{MHz}) \delta 29.6$ $(\mathrm{CH}), 30.5\left(\mathrm{CH}_{3}\right), 32.8\left(\mathrm{CH}_{2}\right), 35.5\left(\mathrm{CH}_{2}\right), 46.2(\mathrm{CH}), 50.8(\mathrm{CH})$, $52.6\left(\mathrm{CH}_{3}\right), 64.7\left(\mathrm{CH}_{2}\right), 70.1(\mathrm{CH}), 109.5(\mathrm{CH}), 112.4(\mathrm{C}), 117.9$ $(\mathrm{CH}), 120.3(\mathrm{CH}), 122.2(\mathrm{CH}), 124.5(\mathrm{C}), 125.5(\mathrm{CH}), 127.7$ (CH), $128.8(\mathrm{CH}), 131.3(\mathrm{C}), 137.7(\mathrm{C}), 138.0(\mathrm{C}), 170.2(\mathrm{C})$, $172.0(\mathrm{C})$.

Methyl (3R,7S,8aS)- $\alpha$-(2-Indolyl)-5-oxo-3-phenyl-2,3,6,7,8,8a-hexahydro-5H-oxazolo[3,2-a]pyridine-7-acetate (4b). LDA ( $3.72 \mathrm{~mL}$ of a $1.5 \mathrm{M}$ solution in cyclohexane, $5.58 \mathrm{mmol})$ was added to a solution of ester $3 \mathbf{b}^{26}(520 \mathrm{mg}, 2.75 \mathrm{mmol})$ in THF $(48 \mathrm{~mL})$ at $-78^{\circ} \mathrm{C}$. After $1 \mathrm{~h}$, a solution of trans-2 $(400$ $\mathrm{mg}, 1.86 \mathrm{mmol})$ in THF ( $5 \mathrm{~mL}$ ) was added via cannula, and the mixture was stirred at $-78{ }^{\circ} \mathrm{C}$ for $5 \mathrm{~h}$. The resulting mixture was poured into saturated aqueous $\mathrm{NaHCO}_{3}$ and

(26) Moody, C. J.; Rahimtoola, K. F. J. Chem. Soc., Perkin Trans. 1 1990, 673 . 
extracted with EtOAc. The combined organic extracts were dried and concentrated to give an oil. Flash chromatography $\left(\mathrm{Et}_{2} \mathrm{O}\right)$ afforded $(\alpha S)-\mathbf{4 b}$ and $(\alpha R)-\mathbf{4 b}(380 \mathrm{mg}$, overall yield $51 \%, 63: 37$ ratio). $(\alpha S)-4 \mathbf{b}$ (lower $R_{f}$ ): IR (film) 3300, 1734, 1646 $\mathrm{cm}^{-1} ;{ }^{1} \mathrm{H}$ NMR $(300 \mathrm{MHz}) \delta 1.90(\mathrm{~m}, 2 \mathrm{H}), 2.34(\mathrm{dd}, J=17.0$, $7.0 \mathrm{~Hz}, 1 \mathrm{H}), 2.64(\mathrm{dd}, J=17.0,5.0 \mathrm{~Hz}, 1 \mathrm{H}), 2.83(\mathrm{~m}, 1 \mathrm{H})$, $3.73(\mathrm{dd}, J=8.7,7.5 \mathrm{~Hz}, 1 \mathrm{H}), 3.74(\mathrm{~s}, 3 \mathrm{H}), 3.80(\mathrm{~d}, J=10.5$ $\mathrm{Hz}, 1 \mathrm{H}), 4.44\left(\mathrm{t}_{\mathrm{ap}}, J=8.5 \mathrm{~Hz}, 1 \mathrm{H}\right), 4.97\left(\mathrm{t}_{\mathrm{ap}}, J=5.2 \mathrm{~Hz}, 1 \mathrm{H}\right)$, $5.38\left(\mathrm{t}_{\mathrm{ap}}, J=7.8 \mathrm{~Hz}, 1 \mathrm{H}\right), 6.44(\mathrm{~d}, J=2.0 \mathrm{~Hz}, 1 \mathrm{H}), 7.11(\mathrm{tm}$, $J=7.5 \mathrm{~Hz}, 1 \mathrm{H}), 7.19(\mathrm{tm}, J=7.2 \mathrm{~Hz}, 1 \mathrm{H}), 7.22-7.41(\mathrm{~m}, 6$ $\mathrm{H}), 7.56(\mathrm{~d}, J=7.7 \mathrm{~Hz}, 1 \mathrm{H}), 8.75(\mathrm{br} \mathrm{s}, 1 \mathrm{H}) ;{ }^{13} \mathrm{C}$ NMR $(75.4$ $\mathrm{MHz}) \delta 29.6\left(\mathrm{CH}_{2}\right), 32.7(\mathrm{CH}), 36.5\left(\mathrm{CH}_{2}\right), 48.9(\mathrm{CH}), 52.6$ $\left(\mathrm{CH}_{3}\right), 58.0(\mathrm{CH}), 71.7\left(\mathrm{CH}_{2}\right), 85.7(\mathrm{CH}), 102.7(\mathrm{CH}), 111.1(\mathrm{CH})$, $119.9(\mathrm{CH}), 120.2(\mathrm{CH}), 122.1(\mathrm{CH}), 125.7(\mathrm{CH}), 128.8(\mathrm{CH})$, $127.6(\mathrm{CH}), 127.6(\mathrm{C}), 131.8(\mathrm{CH}), 136.4(\mathrm{C}), 139.4(\mathrm{C}), 168.6$ (C), $172.4(\mathrm{C}) ;[\alpha]^{22}{ }_{\mathrm{D}}+12.2$ ( $\mathrm{C}_{24} \mathrm{H}_{24} \mathrm{~N}_{2} \mathrm{O}_{4} 404.1736$, found 404.1734. $(\alpha R)$-4b (higher $R_{f}$ ): IR (film) 3300, 1734, $1647 \mathrm{~cm}^{-1} ;{ }^{1} \mathrm{H}$ NMR $(300 \mathrm{MHz}) \delta 2.09$ (dt, $J$ $=14.2,5.0 \mathrm{~Hz}, 1 \mathrm{H}), 2.19(\mathrm{ddd}, J=14.2,7.7,5.5 \mathrm{~Hz}, 1 \mathrm{H})$, $2.23(\mathrm{dd}, J=17.0,7.5 \mathrm{~Hz}, 1 \mathrm{H}), 2.40(\mathrm{dd}, J=17.0,5.0 \mathrm{~Hz}, 1$ $\mathrm{H}), 2.76(\mathrm{~m}, 1 \mathrm{H}), 3.77(\mathrm{~s}, 3 \mathrm{H}), 3.77$ (masked, $1 \mathrm{H}), 3.80(\mathrm{~d}, J$ $=10.2 \mathrm{~Hz}, 1 \mathrm{H}), 4.48\left(\mathrm{t}_{\mathrm{ap}}, J=8.5 \mathrm{~Hz}, 1 \mathrm{H}\right), 5.07\left(\mathrm{t}_{\mathrm{ap}}, J=5.2\right.$ $\mathrm{Hz}, 1 \mathrm{H}), 5.37\left(\mathrm{t}_{\mathrm{ap}}, J=8.0 \mathrm{~Hz}, 1 \mathrm{H}\right), 6.40(\mathrm{~d}, J=2.0 \mathrm{~Hz}, 1 \mathrm{H})$, $7.09(\mathrm{tm}, J=7.5 \mathrm{~Hz}, 1 \mathrm{H}), 7.17(\mathrm{tm}, J=7.3 \mathrm{~Hz}, 1 \mathrm{H}), 7.20-$ $7.39(\mathrm{~m}, 6 \mathrm{H}), 7.54(\mathrm{~d}, J=7.7 \mathrm{~Hz}, 1 \mathrm{H}), 8.70(\mathrm{br} \mathrm{s}, 1 \mathrm{H}) ;{ }^{13} \mathrm{C}$ NMR $(75.4 \mathrm{MHz}) \delta 31.0\left(\mathrm{CH}_{2}\right), 33.0(\mathrm{CH}), 35.1\left(\mathrm{CH}_{2}\right), 48.9$ $(\mathrm{CH}), 52.6\left(\mathrm{CH}_{3}\right), 58.1(\mathrm{CH}), 71.8\left(\mathrm{CH}_{2}\right), 85.8(\mathrm{CH}), 103.1(\mathrm{CH})$, $111.0(\mathrm{CH}), 120.0(\mathrm{CH}), 120.3(\mathrm{CH}), 122.2(\mathrm{CH}), 125.8(\mathrm{CH})$, $128.8(\mathrm{CH}), 127.5(\mathrm{C}), 127.6(\mathrm{CH}), 131.7(\mathrm{CH}), 136.4(\mathrm{C}), 139.5$ (C), 168.7 (C), 172.4 (C); mp 168-171 ${ }^{\circ} \mathrm{C}$ ( $\mathrm{Et}_{2} \mathrm{O}$-acetonehexane); $[\alpha]^{22}{ }_{\mathrm{D}}-45.1$ (c 0.2, EtOH). Anal. Calcd for $\mathrm{C}_{24} \mathrm{H}_{24} \mathrm{~N}_{2} \mathrm{O}_{4}$. $1 /{ }_{2} \mathrm{H}_{2} \mathrm{O}$ : C, 69.71; H, 6.09; N, 6.77. Found: C, 69.73; H, 5.90; $\mathrm{N}, 6.80$.

[1S,5S,6S(and 6R)]-2-[(1R)-2-Hydroxy-1-phenylethyl]6-(methoxycarbonyl)-3-oxo-1,2,3,4,5,6-hexahydro-1,5-methanoazocino[4,3-b]indole $[(16 S)-5 b$ and $(16 R)-5 b] . \mathrm{TiCl}_{4}(90$ $\mu \mathrm{L}, 0.82 \mathrm{mmol})$ was added to a cooled $\left(0^{\circ} \mathrm{C}\right)$ solution of $(\alpha S)$ 4 b $(100 \mathrm{mg}, 0.25 \mathrm{mmol})$ in $\mathrm{CH}_{2} \mathrm{Cl}_{2}(3 \mathrm{~mL})$, and the mixture was stirred at $\mathrm{rt}$ for $5 \mathrm{~h}$, poured into saturated aqueous $\mathrm{NaHCO}_{3}$, and extracted with $\mathrm{CH}_{2} \mathrm{Cl}_{2}$. The combined organic extracts were dried and concentrated, and the resulting residue was chromatographed (EtOAc) to give (16S)-5b and (16R)-5b (60 mg, 60\%, 58:42 ratio). Similarly, starting from $(\alpha R)-4 \mathbf{b}(125 \mathrm{mg}, 0.31 \mathrm{mmol}), \mathrm{CH}_{2} \mathrm{Cl}_{2}(4 \mathrm{~mL})$, and $\mathrm{TiCl}_{4}(50$ $\mu \mathrm{L}, 0.46 \mathrm{mmol}$ ), tetracycles (16S)-5b and (16R)-5b (88 mg, 70\%, 13:87 ratio) were obtained after flash chromatography (EtOAc). (16S)-5b (lower $R_{f}$ ): IR (film) 1734, $1617 \mathrm{~cm}^{-1} ;{ }^{1} \mathrm{H}$ NMR (300 $\mathrm{MHz}) \delta 2.17(\mathrm{dt}, J=13.2,3.4 \mathrm{~Hz}, 1 \mathrm{H}), 2.28(\mathrm{dm}, J=13.2 \mathrm{~Hz}$, $1 \mathrm{H}), 2.46(\mathrm{~d}, J=16.5 \mathrm{~Hz}, 1 \mathrm{H}), 3.13(\mathrm{~m}, 1 \mathrm{H}), 3.13(\mathrm{~m}, 1 \mathrm{H})$, $3.73(\mathrm{~s}, 3 \mathrm{H}), 3.78(\mathrm{br} \mathrm{s}, 1 \mathrm{H}), 3.85(\mathrm{dm}, J=12.4 \mathrm{~Hz}, 1 \mathrm{H}), 4.04$ (ddd, $J=12.4,9.4,6.2 \mathrm{~Hz}, 1 \mathrm{H}), 4.57\left(\mathrm{t}_{\mathrm{ap}}, J=3.0 \mathrm{~Hz}, 1 \mathrm{H}\right)$, $4.86(\mathrm{dd}, J=6.2,2.5 \mathrm{~Hz}, 1 \mathrm{H}), 4.90(\mathrm{~m}, 1 \mathrm{H}), 7.10-7.50(\mathrm{~m}, 9$ $\mathrm{H}), 8.50(\mathrm{br} \mathrm{s}, 1 \mathrm{H}) ;{ }^{13} \mathrm{C} \mathrm{NMR}(75.4 \mathrm{MHz}) \delta 28.1(\mathrm{CH}), 29.7$ $\left(\mathrm{CH}_{2}\right), 39.2\left(\mathrm{CH}_{2}\right), 47.0(\mathrm{CH}), 51.0(\mathrm{CH}), 52.6\left(\mathrm{CH}_{3}\right), 64.7\left(\mathrm{CH}_{2}\right)$, $70.4(\mathrm{CH}), 111.4(\mathrm{CH}), 113.9(\mathrm{C}), 118.1(\mathrm{CH}), 120.6(\mathrm{CH}), 122.7$ $(\mathrm{CH}), 125.1(\mathrm{C}), 127.4(\mathrm{CH}), 128.8(\mathrm{CH}), 127.7(\mathrm{CH}), 128.2(\mathrm{C})$, $136.2(\mathrm{C}), 137.6(\mathrm{C}), 170.8(\mathrm{C}), 171.0(\mathrm{C}) ;[\alpha]^{22} \mathrm{D}-2.0(c \quad 0.55$, EtOH); MS-EI m/z $404\left(\mathrm{M}^{+}, 10\right), 268$ (10), 245 (34), 225 (70), 193 (100), 161 (75), 148 (33); HMRS calcd for $\mathrm{C}_{24} \mathrm{H}_{24} \mathrm{~N}_{2} \mathrm{O}_{4}$ 404.1736, found 404.1739. (16R)-5b (higher $R_{f}$ ): IR (film) 1733 , $1620(\mathrm{NCO}) \mathrm{cm}^{-1} ;{ }^{1} \mathrm{H}$ NMR $(300 \mathrm{MHz}) \delta 2.05(\mathrm{dm}, J=13.0$ $\mathrm{Hz}, 1 \mathrm{H}), 2.27$ (ddd, $J=13.0,4.5,3.0 \mathrm{~Hz}, 1 \mathrm{H}), 2.40(\mathrm{~d}, J=$ $19.0 \mathrm{~Hz}, 1 \mathrm{H}), 3.00(\mathrm{dd}, J=19.0,9.0 \mathrm{~Hz}, 1 \mathrm{H}), 3.20(\mathrm{~m}, 1 \mathrm{H})$, $3.87(\mathrm{~s}, 3 \mathrm{H}), 3.91(\mathrm{dm}, J=14.0 \mathrm{~Hz}, 1 \mathrm{H}), 4.05(\mathrm{~d}, J=4.3 \mathrm{~Hz}$, $1 \mathrm{H}$ ), 4.11 (ddd, $J=14.0,9.3,6.6 \mathrm{~Hz}, 1 \mathrm{H}), 4.59\left(\mathrm{t}_{\mathrm{ap}}, J=2.7\right.$ $\mathrm{Hz}, 1 \mathrm{H}), 4.81$ (dd, $J=9.3,4.4 \mathrm{~Hz}, 1 \mathrm{H}), 4.93(\mathrm{dd}, J=6.6,2.5$ $\mathrm{Hz}, 1 \mathrm{H}), 7.10-7.45(\mathrm{~m}, 9 \mathrm{H}), 9.00$ (br s, $1 \mathrm{H}) ;{ }^{13} \mathrm{C} \mathrm{NMR}(75.4$ $\mathrm{MHz}) \delta 28.3(\mathrm{CH}), 32.8\left(\mathrm{CH}_{2}\right), 35.6\left(\mathrm{CH}_{2}\right), 46.8(\mathrm{CH}), 50.9(\mathrm{CH})$, $52.7\left(\mathrm{CH}_{3}\right), 64.6\left(\mathrm{CH}_{2}\right), 70.2(\mathrm{CH}), 111.5(\mathrm{CH}), 112.5(\mathrm{C}), 118.1$ $(\mathrm{CH}), 120.4(\mathrm{CH}), 122.4(\mathrm{CH}), 125.0(\mathrm{C}), 127.5(\mathrm{CH}), 128.8$ (CH), $127.8(\mathrm{CH}), 129.0(\mathrm{C}), 136.3(\mathrm{C}), 137.7(\mathrm{C}), 171.4(\mathrm{C})$, 171.5 (C); mp $202-206{ }^{\circ} \mathrm{C}\left(\mathrm{Et}_{2} \mathrm{O}\right.$-hexane); MS-EI $\mathrm{m} / z 404\left(\mathrm{M}^{+}\right.$,
5), 373 (3), 284 (30), 268 (5), 245 (87), 225 (25), 193 (35); HMRS calcd for $\mathrm{C}_{24} \mathrm{H}_{24} \mathrm{~N}_{2} \mathrm{O}_{4} 404.1736$, found 404.1735 .

Methyl (3R,7R,8aR)- $\alpha$-(1-Methyl-2-indolyl)-5-oxo-3-phenyl-2,3,6,7,8,8a-hexahydro-5H-oxazolo[3,2-a]pyridine-7acetate (6). Operating as described for the preparation of $\mathbf{4 a}$, from $n-\mathrm{BuLi}(2.2 \mathrm{~mL}$ of a $1.6 \mathrm{M}$ solution in hexanes, $3.5 \mathrm{mmol})$, diisopropylamine $(495 \mu \mathrm{L}, 3.5 \mathrm{mmol}), 3 \mathbf{a}$ (708 mg, $3.5 \mathrm{mmol}$ ), and cis-2 (500 mg, $2.32 \mathrm{mmol})$, epimers $(\alpha S)-6$ and $(\alpha R)-\mathbf{6}(520$ $\mathrm{mg}, 53 \%, 63: 37$ ratio) were obtained after flash chromatography (2:1 EtOAc-hexane). ( $\alpha S)-6$ (higher $R_{f}$ ): IR (film) 1736, $1662 \mathrm{~cm}^{-1} ;{ }^{1} \mathrm{H}$ NMR $(300 \mathrm{MHz}) \delta 2.09(\mathrm{dd}, J=17.0,7.2 \mathrm{~Hz}, 1$ $\mathrm{H}), 2.24$ (ddd, $J=14.0,9.3,7.2 \mathrm{~Hz}, 1 \mathrm{H}$ ), 2.37 (ddd, $J=17.0$, $6.0 \mathrm{~Hz}, 1 \mathrm{H}), 2.40(\mathrm{~m}, 1 \mathrm{H}), 3.00(\mathrm{~m}, 1 \mathrm{H}), 3.72(\mathrm{~s}, 3 \mathrm{H}), 3.73(\mathrm{~s}$, $3 \mathrm{H}), 3.85(\mathrm{~d}, J=11.0 \mathrm{~Hz}, 1 \mathrm{H}), 4.10(\mathrm{dd}, J=9.0,0.9 \mathrm{~Hz}, 1$ $\mathrm{H}), 4.24(\mathrm{dd}, J=9.0,6.0 \mathrm{~Hz}, 1 \mathrm{H}), 4.94(\mathrm{dd}, J=6.0,0.9 \mathrm{~Hz}$, $1 \mathrm{H}), 5.11$ (dd, $J=9.3,4.5 \mathrm{~Hz}, 1 \mathrm{H}), 6.50(\mathrm{~s}, 1 \mathrm{H}), 7.09$ (tm, $J$ $=7.8 \mathrm{~Hz}, 1 \mathrm{H}), 7.15-7.38(\mathrm{~m}, 7 \mathrm{H}), 7.56(\mathrm{~d}, J=7.8 \mathrm{~Hz}, 1 \mathrm{H})$. ${ }^{13} \mathrm{C}$ NMR $(75.4 \mathrm{MHz}) \delta 29.9\left(\mathrm{CH}_{3}\right), 31.7\left(\mathrm{CH}_{2}\right), 32.9(\mathrm{CH}), 35.4$ $\left(\mathrm{CH}_{2}\right), 47.7(\mathrm{CH}), 52.6\left(\mathrm{CH}_{3}\right), 58.4(\mathrm{CH}), 74.3\left(\mathrm{CH}_{2}\right), 86.0(\mathrm{CH})$, $101.1(\mathrm{CH}), 109.3(\mathrm{CH}), 119.9(\mathrm{CH}), 120.5(\mathrm{CH}), 121.9(\mathrm{CH})$, $126.3(\mathrm{CH}), 128.6(\mathrm{CH}), 127.4(\mathrm{C}), 127.7(\mathrm{CH}), 134.8(\mathrm{C}), 137.4$ (C), 140.9 (C), $166.5(\mathrm{C}), 171.3(\mathrm{C}) ; \mathrm{mp} 132-140{ }^{\circ} \mathrm{C} ;[\alpha]^{22} \mathrm{D}$ -10.5 ( c 1.0, $\mathrm{CHCl}_{3}$ ); MS-EI $\mathrm{m} / z 418\left(\mathrm{M}^{+}, 13\right), 325$ (57), 136 (45), 108 (76); HMRS calcd for $\mathrm{C}_{25} \mathrm{H}_{26} \mathrm{~N}_{2} \mathrm{O}_{4} 418.1892$, found 418.1891. $(\alpha R)-6$ (lower $\left.R_{f}\right)$ : IR $(\mathrm{NaCl}) 1736,1666 \mathrm{~cm}^{-1} ;{ }^{1} \mathrm{H}$ NMR $(300 \mathrm{MHz}) \delta 2.03$ (ddd, $J=14.0,9.0,7.5 \mathrm{~Hz}, 1 \mathrm{H}), 2.21$ $(\mathrm{dt}, J=14.0,4.5 \mathrm{~Hz}, 1 \mathrm{H}), 2.28(\mathrm{dd}, J=17.0,7.0 \mathrm{~Hz}, 1 \mathrm{H})$; $2.61(\mathrm{dd}, J=17.0,5.7 \mathrm{~Hz}, 1 \mathrm{H}), 3.14(\mathrm{~m}, 1 \mathrm{H}), 3.66(\mathrm{~s}, 3 \mathrm{H})$, $3.79(\mathrm{~s}, 3 \mathrm{H}), 3.85(\mathrm{~d}, J=10.8 \mathrm{~Hz}, 1 \mathrm{H}), 4.03$ (dd, $J=9.3,0.9$ $\mathrm{Hz}, 1 \mathrm{H}), 4.15(\mathrm{dd}, J=9.3,6.6 \mathrm{~Hz}, 1 \mathrm{H}), 4.88(\mathrm{dd}, J=9.0,4.5$ $\mathrm{Hz}, 1 \mathrm{H}), 4.94(\mathrm{~d}, J=6.6 \mathrm{~Hz}, 1 \mathrm{H}), 6.52(\mathrm{~s}, 1 \mathrm{H}), 7.14(\mathrm{tm}, J=$ $7.8 \mathrm{~Hz}, 1 \mathrm{H}), 7.20-7.38(\mathrm{~m}, 7 \mathrm{H}), 7.60(\mathrm{~d}, J=7.8 \mathrm{~Hz}, 1 \mathrm{H}) ;{ }^{13} \mathrm{C}$ NMR $(75.4 \mathrm{MHz}) \delta 30.0\left(\mathrm{CH}_{3}\right), 30.9\left(\mathrm{CH}_{2}\right), 31.6(\mathrm{CH}), 36.3$ $\left(\mathrm{CH}_{2}\right), 48.0(\mathrm{CH}), 52.6\left(\mathrm{CH}_{3}\right), 58.5(\mathrm{CH}), 74.2\left(\mathrm{CH}_{2}\right), 85.9(\mathrm{CH})$, $101.5(\mathrm{CH}), 109.3(\mathrm{CH}), 119.9(\mathrm{CH}), 120.5(\mathrm{CH}), 121.9(\mathrm{CH})$, $126.3(\mathrm{CH}), 128.6(\mathrm{CH}), 127.5(\mathrm{C}), 127.7(\mathrm{CH}), 134.4(\mathrm{C}), 137.5$ (C), $140.9(\mathrm{C}), 166.5(\mathrm{C}), 171.3(\mathrm{C}) ;[\alpha]^{22}{ }_{\mathrm{D}}-18.8\left(c \mathrm{1}\right.$.0, $\left.\mathrm{CHCl}_{3}\right)$; MS-EI $m / z 418\left(\mathrm{M}^{+}, 96\right), 325$ (17), 287 (100), 203 (76); HMRS calcd for $\mathrm{C}_{25} \mathrm{H}_{26} \mathrm{~N}_{2} \mathrm{O}_{4} 418.1892$, found 418.1891.

$(1 R, 5 R, 6 S)-2-[(1 R)-2-H y d r o x y-1-p h e n y l e t h y l]-6-(m e t h-$ oxycarbonyl)-7-methyl-3-oxo-1,2,3,4,5,6-hexahydro-1,5methanoazocino[4,3-b] indole [(16S)-7]. $\mathrm{TiCl}_{4}(35 \mu \mathrm{L}, 0.32$ $\mathrm{mmol})$ was added to a solution of $(\alpha S)-6(135 \mathrm{mg}, 0.32 \mathrm{mmol})$ in $\mathrm{CH}_{2} \mathrm{Cl}_{2}(2 \mathrm{~mL})$ at $\mathrm{rt}$, and the resulting mixture was heated at reflux for $2 \mathrm{~h}$. $\mathrm{TiCl}_{4}(35 \mu \mathrm{L}, 0.32 \mathrm{mmol})$ was added twice after 2 and $6 \mathrm{~h}$, and the mixture was heated at reflux for an additional $18 \mathrm{~h}$. The mixture was poured into saturated aqueous $\mathrm{NaHCO}_{3}$ and extracted with $\mathrm{CH}_{2} \mathrm{Cl}_{2}$. The combined organic extracts were dried and concentrated, and the resulting residue was chromatographed (4:1 EtOAc-hexane to EtOAc) to give (16S)-7 (34 mg, 25\%): IR (film) 3350, 1735, $1620 \mathrm{~cm}^{-1} ;{ }^{1} \mathrm{H}$ NMR $(300 \mathrm{MHz}) \delta 1.90(\mathrm{dm}, J=13.0 \mathrm{~Hz}, 1 \mathrm{H})$, $2.24(\mathrm{dt}, J=13.0,3.3 \mathrm{~Hz}, 1 \mathrm{H}), 2.52(\mathrm{~d}, J=19.0 \mathrm{~Hz}, 1 \mathrm{H})$, $2.85(\mathrm{dd}, J=19.0,8.1 \mathrm{~Hz}, 1 \mathrm{H}), 3.13(\mathrm{~m}, 1 \mathrm{H}), 3.54(\mathrm{~s}, 3 \mathrm{H})$, $3.83(\mathrm{~s}, 3 \mathrm{H}), 4.14(\mathrm{~d}, J=6.3 \mathrm{~Hz}, 1 \mathrm{H}), 4.18-4.25(\mathrm{~m}, 2 \mathrm{H})$, 4.54 (dd, $J=3.6,2.6 \mathrm{~Hz}, 1 \mathrm{H}), 5.67$ (t, $J=7.0 \mathrm{~Hz}, 1 \mathrm{H}), 7.10-$ $7.50(\mathrm{~m}, 9 \mathrm{H}) ;{ }^{13} \mathrm{C} \mathrm{NMR}(75.4 \mathrm{MHz}) \delta 29.3(\mathrm{CH}), 30.4\left(\mathrm{CH}_{3}\right)$, $33.6\left(\mathrm{CH}_{2}\right), 34.9\left(\mathrm{CH}_{2}\right), 46.2(\mathrm{CH}), 47.4(\mathrm{CH}), 52.6\left(\mathrm{CH}_{3}\right), 62.3$ $(\mathrm{CH}), 63.1\left(\mathrm{CH}_{2}\right), 109.3(\mathrm{CH}), 113.0(\mathrm{C}), 118.0(\mathrm{CH}), 119.8(\mathrm{CH})$, $122.0(\mathrm{CH}), 124.4(\mathrm{C}), 127.5(\mathrm{CH}), 127.6(\mathrm{CH}), 128.6(\mathrm{CH})$, 131.6 (C), 136.6 (C), 137.3 (C), 170.8 (C), 172.3 (C); mp $118{ }^{\circ} \mathrm{C}$ $\left(\mathrm{Et}_{2} \mathrm{O}-\mathrm{CH}_{2} \mathrm{Cl}_{2}\right) ;[\alpha]^{22}{ }_{\mathrm{D}}+40.5\left(c 1.0, \mathrm{CHCl}_{3}\right)$.

$(1 R, 5 R, 6 R)-2-[(1 R)-2-H y d r o x y-1-p h e n y l e t h y l]-6-(m e t h-$ oxycarbonyl)-7-methyl-3-oxo-1,2,3,4,5,6-hexahydro-1,5methanoazocino $[4,3-b]$ indole $[(\mathbf{1 6 R})-7]$. $\mathrm{TiCl}_{4}(125 \mu \mathrm{L}, 0.12$ mmol) was added to a solution of $(\alpha R)-6(190 \mathrm{mg}, 0.45 \mathrm{mmol})$ in $\mathrm{CH}_{2} \mathrm{Cl}_{2}(10 \mathrm{~mL})$, and the resulting mixture was heated at reflux $17 \mathrm{~h} . \mathrm{TiCl}_{4}(50 \mu \mathrm{L}, 0.45 \mathrm{mmol})$ was added, and the mixture was heated at reflux for an additional $4 \mathrm{~h}$, poured into saturated solution $\mathrm{NaHCO}_{3}$, and extracted with $\mathrm{CH}_{2} \mathrm{Cl}_{2}$. The combined organic extracts were dried and concentrated, and the resulting residue was chromatographed (4:1 EtOAc- 
hexane, 4.9:0.1 EtOAc-EtOH) to afford (16R)-7 (38 mg, 20\%): IR (film) 3375, 1733, $1624 \mathrm{~cm}^{-1} ;{ }^{1} \mathrm{H}$ NMR $(300 \mathrm{MHz}) \delta$ $2.00(\mathrm{dt}, J=13.0,3.0 \mathrm{~Hz}, 1 \mathrm{H}), 2.20(\mathrm{dm}, J=13.0 \mathrm{~Hz}, 1 \mathrm{H})$, $2.47(\mathrm{~d}, J=18.6 \mathrm{~Hz}, 1 \mathrm{H}), 3.05(\mathrm{dm}, J=9.6 \mathrm{~Hz}, 1 \mathrm{H}), 3.16$ (dd, $J=18.6,9.3 \mathrm{~Hz}, 1 \mathrm{H}), 3.38(\mathrm{br} \mathrm{s}, 1 \mathrm{H}), 3.58(\mathrm{~s}, 3 \mathrm{H}), 3.68$ $(\mathrm{s}, 3 \mathrm{H}), 3.80(\mathrm{~d}, J=1.2 \mathrm{~Hz}, 1 \mathrm{H}), 4.25(\mathrm{~m}, 2 \mathrm{H}), 4.52(\mathrm{t}, J=$ $2.4 \mathrm{~Hz}, 1 \mathrm{H}), 5.57(\mathrm{t}, J=6.3 \mathrm{~Hz}, 1 \mathrm{H}), 7.00-7.40(\mathrm{~m}, 9 \mathrm{H}) ;{ }^{13} \mathrm{C}$ NMR (75.4 MHz) $\delta 29.6(\mathrm{CH}), 29.8\left(\mathrm{CH}_{2}\right), 30.1\left(\mathrm{CH}_{3}\right), 38.5$ $\left(\mathrm{CH}_{2}\right), 47.2(\mathrm{CH}), 47.5(\mathrm{CH}), 52.5\left(\mathrm{CH}_{3}\right), 63.3(\mathrm{CH}), 63.7\left(\mathrm{CH}_{2}\right)$, $109.2(\mathrm{CH}), 112.5(\mathrm{C}), 118.3(\mathrm{CH}), 119.6(\mathrm{CH}), 121.9(\mathrm{CH})$, $124.5(\mathrm{C}), 127.6(\mathrm{CH}), 127.7(\mathrm{CH}), 128.6(\mathrm{CH}), 130.6(\mathrm{C}), 136.4$ (C), $137.3(\mathrm{C}), 171.5(\mathrm{C}), 171.5(\mathrm{C}) ;[\alpha]^{22} \mathrm{D}+35.6\left(c 1.0, \mathrm{CHCl}_{3}\right)$.

$(3 R, 8 S, 8 a R)-8$-Ethyl-5-oxo-3-phenyl-2,3,8,8a-tetrahydro$\mathbf{5 H}$-oxazolo[3,2-a]pyridine (10). Operating as described for the preparation of trans-2, starting from $\mathbf{9}^{27}(500 \mathrm{mg}, 2.04$ $\mathrm{mmol})$, THF $(20 \mathrm{~mL})$, methyl phenylsulfinate $(636 \mathrm{mg}, 4.08$ $\mathrm{mmol}$ ) and $\mathrm{KH}$ (400 mg, $20 \mathrm{wt} \%$ dispersion in mineral oil, 10 mmol), (3R,8S,8aR)-8-ethyl-5-oxo-3-phenyl-6-(phenylsulfinyl)-2,3,6,7,8,8a-hexahydro-5H-oxazolo[3,2-a]pyridine $(715$ $\mathrm{mg}, 95 \%$ ) was obtained as a mixture of isomers. Major isomer: IR (film) $1658 \mathrm{~cm}^{-1} ;{ }^{1} \mathrm{H}$ NMR $(300 \mathrm{MHz}$, selected resonances) $\delta 0.93(\mathrm{t}, J=7.2 \mathrm{~Hz}, 3 \mathrm{H}), 3.37(\mathrm{dd}, J=10.5,7.8$ $\mathrm{Hz}, 1 \mathrm{H}), 4.08$ (dd, $J=9.0,1.2 \mathrm{~Hz}, 1 \mathrm{H}), 4.17$ (dd, $J=9.0,6.9$ $\mathrm{Hz}, 1 \mathrm{H}), 4.58(\mathrm{~d}, J=8.7,1 \mathrm{H}), 4.99(\mathrm{~d}, J=6.9 \mathrm{~Hz}, 1 \mathrm{H}) ;{ }^{13} \mathrm{C}$ NMR $(75.4 \mathrm{MHz}) \delta 10.7\left(\mathrm{CH}_{3}\right), 18.3\left(\mathrm{CH}_{2}\right), 23.9\left(\mathrm{CH}_{2}\right), 39.8$ $(\mathrm{CH}), 59.6(\mathrm{CH}), 65.7(\mathrm{CH}), 73.6\left(\mathrm{CH}_{2}\right), 91.4(\mathrm{CH}), 140.6(\mathrm{C})$, 141.2 (C), 161.7 (C). A solution of the $\beta$-keto sulfoxide (600 $\mathrm{mg}, 1.62 \mathrm{mmol})$ in toluene $(15 \mathrm{~mL})$ was heated in the presence of $\mathrm{NaCO}_{3}(1.0 \mathrm{~g}, 9.0 \mathrm{mmol})$ to give $\mathbf{1 0}(335 \mathrm{mg}, 85 \%)$ after flash chromatography (7:3 EtOAc-hexane): IR (film) $1670 \mathrm{~cm}^{-1} ;{ }^{1} \mathrm{H}$ NMR $(300 \mathrm{MHz}) \delta 1.10(\mathrm{t}, J=7.8 \mathrm{~Hz}, 3 \mathrm{H}), 1.59(\mathrm{~m}, 1 \mathrm{H})$, $1.85(\mathrm{~m}, 1 \mathrm{H}), 2.67(\mathrm{~m}, 1 \mathrm{H}), 4.11(\mathrm{dd}, J=9.0,1.5 \mathrm{~Hz}, 1 \mathrm{H})$, 4.19 (dd, $J=9.0,6.6 \mathrm{~Hz}, 1 \mathrm{H}), 4.81$ (d, $J=10.8 \mathrm{~Hz}, 1 \mathrm{H}), 5.04$ $(\mathrm{dd}, J=6.6,1.5 \mathrm{~Hz}, 1 \mathrm{H}), 5.93(\mathrm{dd}, J=9.9,3.0 \mathrm{~Hz}, 1 \mathrm{H}), 6.39$ (dd, $J=9.9,1.8 \mathrm{~Hz}, 1 \mathrm{H}), 7.10-7.35(\mathrm{~m}, 5 \mathrm{H}) ;{ }^{13} \mathrm{C}$ NMR $(75.4$ $\mathrm{MHz}) \delta 10.8\left(\mathrm{CH}_{3}\right), 23.1\left(\mathrm{CH}_{2}\right), 42.4(\mathrm{CH}), 57.5(\mathrm{CH}), 74.1$ $\left(\mathrm{CH}_{2}\right), 91.0(\mathrm{CH}), 125.5(\mathrm{CH}), 126.3(\mathrm{CH}), 128.4(\mathrm{CH}), 127.4$ (CH), $140.8(\mathrm{C}), 141.3(\mathrm{CH}), 161.1(\mathrm{C})$; $[\alpha]^{22}{ }_{\mathrm{D}}+116.1(c$ 1.0, $\mathrm{CHCl}_{3}$ ).

Methyl (3R,7R,8S,8aR)-8-Ethyl- $\alpha$-(1-methyl-2-indolyl)5-oxo-3-phenyl-2,3,6,7,8,8a-hexahydro-5H-oxazolo[3,2-a]pyridine-7-acetate (11a). A solution of 3a $(499 \mathrm{mg}, 2.46$ $\mathrm{mmol})$ in THF ( $7 \mathrm{~mL}$ ) was added dropwise to a cooled solution $\left(-78{ }^{\circ} \mathrm{C}\right)$ of $\mathrm{LDA}(1.64 \mathrm{~mL}$ of a $1.5 \mathrm{M}$ solution in cyclohexane, $2.46 \mathrm{mmol})$ in THF $(6 \mathrm{~mL})$. After the mixture was stirred at $-78^{\circ} \mathrm{C}$ for $1 \mathrm{~h}$, HMPA $(432 \mu \mathrm{L}, 2.46 \mathrm{mmol})$ and a solution of $10(300 \mathrm{mg}, 1.23 \mathrm{mmol})$ in $\mathrm{THF}(4 \mathrm{~mL})$ were added via cannula at $-78{ }^{\circ} \mathrm{C}$. The mixture was stirred at $0{ }^{\circ} \mathrm{C}$ for $3 \mathrm{~h}$ and at $\mathrm{rt}$ for $18 \mathrm{~h}$, poured into saturated aqueous $\mathrm{NH}_{4} \mathrm{Cl}$, and extracted with EtOAc. The combined organic extracts were washed with water, dried, and concentrated to give an oil. Flash chromatography (8:2 EtOAc-hexane) afforded $(\alpha S)$-11a and $(\alpha R)$-11a (458 mg, 83\%, 3:7 ratio). ( $\alpha S$ )-11a (lower $R_{f}$ ): IR (film) 1736, $1661 \mathrm{~cm}^{-1} ;{ }^{1} \mathrm{H}$ NMR $(300 \mathrm{MHz}) \delta 0.94(\mathrm{t}, J=7.5 \mathrm{~Hz}, 3 \mathrm{H})$, $1.62(\mathrm{~m}, 1 \mathrm{H}), 1.70(\mathrm{~m}, 1 \mathrm{H}), 1.76(\mathrm{~m}, 1 \mathrm{H}), 2.44(\mathrm{dd}, J=17.1$, $7.0 \mathrm{~Hz}, 1 \mathrm{H}), 2.60(\mathrm{dd}, J=17.1,4.2 \mathrm{~Hz}, 1 \mathrm{H}), 2.59(\mathrm{~m}, 1 \mathrm{H})$, $3.55(\mathrm{~s}, 3 \mathrm{H}), 3.57(\mathrm{~s}, 3 \mathrm{H}), 3.76(\mathrm{~d}, J=8.7 \mathrm{~Hz}, 1 \mathrm{H}), 4.18(\mathrm{~m}$, $2 \mathrm{H}), 4.70(\mathrm{~d}, J=8.0 \mathrm{~Hz}, 1 \mathrm{H}), 4.98(\mathrm{t}, J=4.0 \mathrm{~Hz}, 1 \mathrm{H}), 6.46$ $(\mathrm{s}, 1 \mathrm{H}), 7.10(\mathrm{tm}, J=7.8 \mathrm{~Hz}, 1 \mathrm{H}), 7.21(\mathrm{tm}, J=8.1 \mathrm{~Hz}, 1 \mathrm{H})$, $7.28-7.44(\mathrm{~m}, 6 \mathrm{H}), 7.56(\mathrm{dm}, J=7.8 \mathrm{~Hz}, 1 \mathrm{H}) ;{ }^{13} \mathrm{C} \mathrm{NMR}(75.4$ $\mathrm{MHz}) \delta 10.3\left(\mathrm{CH}_{3}\right), 25.1\left(\mathrm{CH}_{2}\right), 29.8\left(\mathrm{CH}_{3}\right), 35.0\left(\mathrm{CH}_{2}\right), 37.6$ $(\mathrm{CH}), 42.8(\mathrm{CH}), 46.5(\mathrm{CH}), 52.3\left(\mathrm{CH}_{3}\right), 57.6(\mathrm{CH}), 73.9\left(\mathrm{CH}_{2}\right)$, $91.0(\mathrm{CH}), 101.6(\mathrm{CH}), 109.1(\mathrm{CH}), 119.7(\mathrm{CH}), 120.4(\mathrm{CH})$, $121.6(\mathrm{CH}), 126.8(\mathrm{CH}), 128.6(\mathrm{CH}), 127.3(\mathrm{C}), 127.6(\mathrm{CH})$, 134.7 (C), 137.3 (C), 140.9 (C), 167.1 (C), 171.2 (C); mp 149$152{ }^{\circ} \mathrm{C}$ (EtOAc-hexane); $[\alpha]^{22}{ }_{\mathrm{D}}-70.0$ (c 1.0, EtOH). Anal. Calcd for $\mathrm{C}_{27} \mathrm{H}_{30} \mathrm{~N}_{2} \mathrm{O}_{4}$ : C, 72.62; $\mathrm{H}, 6.77 ; \mathrm{N}, 6.27$. Found: C, 72.35; H, 6.77; N, 6.12. $(\alpha R)-11$ a (higher $\left.R_{f}\right)$ : IR (KBr) 1751, $1676 \mathrm{~cm}^{-1} ;{ }^{1} \mathrm{H}$ NMR $(300 \mathrm{MHz}) \delta 1.11(\mathrm{t}, J=7.2,3 \mathrm{H}), 1.71$

(27) Amat, M.; Llor, N.; Hidalgo, J.; Bosch, J. Tetrahedron: Asymmetry 1997, 8, 2237. (m, $1 \mathrm{H}), 1.80(\mathrm{~m}, 1 \mathrm{H}), 1.82(\mathrm{~m}, 1 \mathrm{H}), 2.00(\mathrm{dd}, J=16.0,2.5$ $\mathrm{Hz}, 1 \mathrm{H}), 2.11(\mathrm{dd}, J=16.0,4.5 \mathrm{~Hz}, 1 \mathrm{H}), 2.64(\mathrm{dm}, J=12.0$ $\mathrm{Hz}, 1 \mathrm{H}), 2.90(\mathrm{~s}, 3 \mathrm{H}), 3.51(\mathrm{~d}, J=12.0 \mathrm{~Hz}, 1 \mathrm{H}), 3.68(\mathrm{~s}, 3 \mathrm{H})$, 4.20 (dd, $J=9.3,6.3 \mathrm{~Hz}, 1 \mathrm{H}), 4.25(\mathrm{dd}, J=9.3,1.5 \mathrm{~Hz}, 1 \mathrm{H})$, $4.65(\mathrm{~d}, J=6.3 \mathrm{~Hz}, 1 \mathrm{H}), 4.93(\mathrm{dd}, J=6.3,1.5 \mathrm{~Hz}, 1 \mathrm{H}), 6.40$ (s, $1 \mathrm{H}), 7.00$ (ddd, $J=8.0,6.0,2.0 \mathrm{~Hz}, 1 \mathrm{H}), 7.11$ (ddd, $J=$ 8.0, 8.0, $1.0 \mathrm{~Hz}, 1 \mathrm{H}), 7.33(\mathrm{~d}, J=7.2 \mathrm{~Hz}, 1 \mathrm{H}), 7.40-7.54(\mathrm{~m}$, $5 \mathrm{H}), 7.47(\mathrm{dt}, J=8.0,1.0 \mathrm{~Hz}, 1 \mathrm{H}) ;{ }^{13} \mathrm{C} \mathrm{NMR}(75.4 \mathrm{MHz}) \delta$ $11.2\left(\mathrm{CH}_{3}\right), 27.0\left(\mathrm{CH}_{2}\right), 28.7\left(\mathrm{CH}_{3}\right), 33.2\left(\mathrm{CH}_{2}\right), 40.9(\mathrm{CH}), 45.1$ $(\mathrm{CH}), 47.3(\mathrm{CH}), 52.3\left(\mathrm{CH}_{3}\right), 57.3(\mathrm{CH}), 73.9\left(\mathrm{CH}_{2}\right), 91.5(\mathrm{CH})$, $99.6(\mathrm{CH}), 109.5(\mathrm{CH}), 119.3(\mathrm{CH}), 120.0(\mathrm{CH}), 121.2(\mathrm{CH})$, $127.4(\mathrm{C}), 127.6(\mathrm{CH}), 128.6(\mathrm{CH}), 127.7(\mathrm{CH}), 135.3(\mathrm{C}), 136.9$ (C), 141.0 (C), 167.1 (C), 171.8 (C); mp 166-169 ${ }^{\circ} \mathrm{C}\left(\mathrm{Et}_{2} \mathrm{O}\right)$; $[\alpha]^{22}{ }_{D}-49.0$ (c 1.0, EtOH). Anal. Calcd for $\mathrm{C}_{27} \mathrm{H}_{30} \mathrm{~N}_{2} \mathrm{O}_{4}$ : C, 72.62; H, 6.77; N, 6.27. Found: C, 72.74; H, 6.83; N, 6.28.

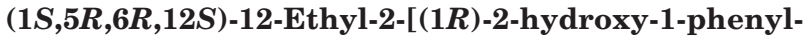
ethyl]-6-(methoxycarbonyl)-7-methyl-3-oxo-1,2,3,4,5,6hexahydro-1,5-methanoazocino[4,3-b]indole $(12 \mathrm{a}) . \mathrm{TiCl}_{4}$ $(120 \mu \mathrm{L}, 1.08 \mathrm{mmol})$ was added to a solution of $(\alpha R)-11 \mathbf{a}(160$ $\mathrm{mg}, 0.36 \mathrm{mmol})$ in $\mathrm{CH}_{2} \mathrm{Cl}_{2}(8 \mathrm{~mL})$, and the resulting mixture was heated at reflux for $5 \mathrm{~h}$. The mixture was poured into saturated aqueous $\mathrm{NaHCO}_{3}$ and extracted with $\mathrm{CH}_{2} \mathrm{Cl}_{2}$. The combined organic extracts were dried and concentrated, and the resulting residue was chromatographed (8:2 EtOAchexane) to give 12a (140 mg, 81\%): IR (KBr) 3375, 1736, 1628 $\mathrm{cm}^{-1} ;{ }^{1} \mathrm{H}$ NMR $(300 \mathrm{MHz}) \delta 0.61\left(\mathrm{t}, J=7.5 \mathrm{~Hz}, 3 \mathrm{H}, \mathrm{CH}_{3}\right)$, $1.39\left(\mathrm{~m}, 2 \mathrm{H}, \mathrm{CH}_{2}\right), 1.80(\mathrm{~m}, 1 \mathrm{H}, \mathrm{H}-12), 2.40(\mathrm{~d}, J=19.0 \mathrm{~Hz}$, $1 \mathrm{H}, \mathrm{H}-4), 2.76$ (dd, $J=19.0,8.7 \mathrm{~Hz}, 1 \mathrm{H}, \mathrm{H}-4), 2.86(\mathrm{~m}, 1 \mathrm{H}$, $\mathrm{H}-5), 3.57\left(\mathrm{~s}, 3 \mathrm{H}, \mathrm{CH}_{3} \mathrm{~N}\right), 3.85\left(\mathrm{~s}, 3 \mathrm{H}, \mathrm{CH}_{3} \mathrm{O}\right), 3.91(\mathrm{dd}, J=$ $12.5,2.7 \mathrm{~Hz}, 1 \mathrm{H}, \mathrm{H}-2^{\prime}$ ), 4.00 (dd, $J=12.5,5.4 \mathrm{~Hz}, 1 \mathrm{H}, \mathrm{H}-2^{\prime}$ ), $4.15(\mathrm{~d}, J=6.0 \mathrm{~Hz}, 1 \mathrm{H}, \mathrm{H}-6), 4.42(\mathrm{~m}, 1 \mathrm{H}, \mathrm{H}-1), 4.69$ (dd, $J$ $\left.=5.4,2.7 \mathrm{~Hz}, 1 \mathrm{H}, \mathrm{H}-1^{\prime}\right), 4.90(\mathrm{br} \mathrm{s}, 1 \mathrm{H}, \mathrm{OH}), 7.10-7.52(\mathrm{~m}$, $8 \mathrm{H}, \mathrm{ArH}), 7.65(\mathrm{dm}, J=7.8 \mathrm{~Hz}, 1 \mathrm{H}, \mathrm{H}-11) ;{ }^{13} \mathrm{C} \mathrm{NMR}(75.4$ $\mathrm{MHz}) \delta 11.1\left(\mathrm{CH}_{3}\right), 23.7\left(\mathrm{CH}_{2}\right), 30.5\left(\mathrm{CH}_{3} \mathrm{~N}\right), 32.0(\mathrm{C}-4), 33.5$ (C-5), 42.8 (C-12), 47.3 (C-6), $52.5\left(\mathrm{CH}_{3} \mathrm{O}\right), 53.8$ (C-1), 64.7 (C-2'), 70.6 (C-1'), 109.5 (C-8), 114.3 (C-11b), 117.7 (C-11), 120.0 (C-10), 121.9 (C-9), 124.5 (C-11a), 127.7 (C-p), 128.2, 128.3 (C-o, $m$ ), 131.3 (C-6a), 137.3 (C-7a), 137.8 (C-i), 169.9 (NCO), 171.8 (COO); $\mathrm{mp} 115-117^{\circ} \mathrm{C} ;[\alpha]^{22} \mathrm{D}-10.5$ (c 1.0, EtOH). Anal. Calcd for $\mathrm{C}_{27} \mathrm{H}_{30} \mathrm{~N}_{2} \mathrm{O}_{4} \cdot 1 \mathrm{CH}_{2} \mathrm{Cl}_{2}$ : C, 68.23; H, 6.44; N, 5.80 . Found: C, 68.23; H, 6.51; N, 5.71.

Methyl (3R,7R,8S,8aR)-8-Ethyl- $\alpha$-(2-indolyl)-5-oxo-3phenyl-2,3,6,7,8,8a-hexahydro- $5 H$-oxazolo[3,2-a]pyridine7-acetate (11b). A solution of $\mathbf{3 b}(1.55 \mathrm{~g}, 8.22 \mathrm{mmol})$ in THF $(25 \mathrm{~mL})$ was added to a cooled $\left(-78^{\circ} \mathrm{C}\right)$ solution of LDA $(10.9$ $\mathrm{mL}$ of $1.5 \mathrm{M}$ solution in cyclohexane, $16.4 \mathrm{mmol})$ in THF (20 $\mathrm{mL}$ ). After the mixture was stirred at $-78^{\circ} \mathrm{C}$ for $1 \mathrm{~h}$, HMPA $(1.44 \mathrm{~mL}, 8.2 \mathrm{mmol})$ and $\mathrm{CuCN}(734 \mathrm{mg}, 8.22 \mathrm{mmol})$ were added. Then, a solution of $\mathbf{1 0}(1.0 \mathrm{~g}, 4.11 \mathrm{mmol})$ in THF (5 $\mathrm{mL}$ ) was added via cannula at $-78^{\circ} \mathrm{C}$. The mixture was stirred at $-78{ }^{\circ} \mathrm{C}$ for $30 \mathrm{~min}$, at $0{ }^{\circ} \mathrm{C}$ for $1 \mathrm{~h}$, and at $\mathrm{rt}$ for $15 \mathrm{~h}$. The resulting mixture was poured into saturated aqueous $\mathrm{NH}_{4} \mathrm{Cl}$ and extracted with $\mathrm{CH}_{2} \mathrm{Cl}_{2}$. The combined organic extracts were washed with saturated aqueous $\mathrm{NaHCO}_{3}$, dried, and concentrated to give an oil. Flash chromatography (6:4 EtOAchexane to EtOAc) afforded $(\alpha S)-\mathbf{1 1 b}$ and $(\alpha R)-\mathbf{1 1 b}(706 \mathrm{mg}$, 40\%, 7:3 ratio), 10 (325 mg), and 5-ethyl-1-[(1R)-2-hydroxy1-phenylethyl]-1H-2-pyridone $(\mathbf{5 6} ; 140 \mathrm{mg})$. ( $\alpha S)$-11b (lower $\left.R_{f}\right)$ : IR (KBr) 3268, 1733, $1665 \mathrm{~cm}^{-1} ;{ }^{1} \mathrm{H}$ NMR $(300 \mathrm{MHz}) \delta$ 0.79 (t, $\left.J=7.5 \mathrm{~Hz}, 3 \mathrm{H}, \mathrm{CH}_{3}\right), 1.50\left(\mathrm{~m}, 2 \mathrm{H}, \mathrm{CH}_{2}\right), 1.90(\mathrm{~m}, 1$ $\mathrm{H}, \mathrm{H}-8), 2.41$ (m, $2 \mathrm{H}, \mathrm{H}-6), 2.45$ (m, $1 \mathrm{H}, \mathrm{H}-7), 3.58$ (s, $3 \mathrm{H}$, $\left.\mathrm{CH}_{3} \mathrm{O}\right), 3.65\left(\mathrm{~d}, J=9.0 \mathrm{~Hz}, 1 \mathrm{H}, \mathrm{CHCO}_{2} \mathrm{Me}\right), 4.16(\mathrm{~m}, 2 \mathrm{H}$, $\mathrm{H}-2), 4.65$ (d, $J=8.4 \mathrm{~Hz}, 1 \mathrm{H}, \mathrm{H}-8 \mathrm{a}), 4.98$ (m, $1 \mathrm{H}, \mathrm{H}-3), 6.37$ (s, $1 \mathrm{H}, \mathrm{H}-3$ ind), 7.09 (t, $J=7.8 \mathrm{~Hz}, 1 \mathrm{H}, \mathrm{H}-5$ ind), 7.17 (t, $J$ $=7.8 \mathrm{~Hz}, 1 \mathrm{H}, \mathrm{H}-6$ ind $), 7.33-7.43(\mathrm{~m}, 6 \mathrm{H}, \mathrm{ArH}), 7.57(\mathrm{~d}, J=$ $7.8 \mathrm{~Hz}, 1 \mathrm{H}, \mathrm{H}-4$ ind), 8.70 (br s, $1 \mathrm{H}, \mathrm{NH}) ;{ }^{13} \mathrm{C} \mathrm{NMR}(75.4$ $\mathrm{MHz}) \delta 10.1\left(\mathrm{CH}_{3}\right), 24.7\left(\mathrm{CH}_{2}\right), 35.1(\mathrm{C}-6), 39.6(\mathrm{C}-7), 42.6$ (C-8), $48.6\left(\mathrm{CHCO}_{2} \mathrm{Me}\right), 52.4\left(\mathrm{CH}_{3} \mathrm{O}\right), 57.8(\mathrm{C}-3), 74.1(\mathrm{C}-2), 91.1$ (C-8a), 102.8 (C-3 ind), 111.0 (C-7 ind), 120.0 (C-4 ind), 120.2 (C-5 ind), 122.1 (C-6 ind), 126.8, 128.6 (C-o, $m$ ), 127.8 (C-p), 128.6 (C-3a ind), 132.6 (C-2 ind), 136.2 (C-i), 140.9 (C-7a ind), $166.6(\mathrm{NCO}), 172.8(\mathrm{COO}) ;[\alpha]^{22}{ }_{\mathrm{D}}-123.6$ (c 0.55, EtOH). Anal. 
Calcd for $\mathrm{C}_{26} \mathrm{H}_{28} \mathrm{~N}_{2} \mathrm{O}_{4} \cdot 1 / 2 \mathrm{H}_{2} \mathrm{O}$ : C, 70.73; H, 6.62; N, 6.34. Found: C, 71.05; H, 7.02; N, 6.05. $(\alpha R)-11 b$ (higher $R_{f}$ ): IR (film) 3298, 1732, $1664 \mathrm{~cm}^{-1}$; ${ }^{1} \mathrm{H}$ NMR $(500 \mathrm{MHz}) \delta 1.09$ (t, $J$ $\left.=7.2 \mathrm{~Hz}, 3 \mathrm{H}, \mathrm{CH}_{3}\right), 1.77\left(\mathrm{~m}, 2 \mathrm{H}, \mathrm{CH}_{2}\right), 1.82(\mathrm{~m}, 1 \mathrm{H}, \mathrm{H}-8)$, $2.13(\mathrm{dd}, J=16.0,4.2 \mathrm{~Hz}, 1 \mathrm{H}, \mathrm{H}-6), 2.24(\mathrm{dd}, J=16.0,5.7$ $\mathrm{Hz}, 1 \mathrm{H}, \mathrm{H}-6), 2.47$ (m, $1 \mathrm{H}, \mathrm{H}-7), 3.65(\mathrm{~d}, J=10.0 \mathrm{~Hz}, 1 \mathrm{H}$, $\mathrm{CHCO}_{2} \mathrm{Me}$ ), $3.76\left(\mathrm{~s}, 3 \mathrm{H}, \mathrm{CH}_{3} \mathrm{O}\right), 4.14(\mathrm{dd}, J=9.0,1.0 \mathrm{~Hz}, 1$ $\mathrm{H}, \mathrm{H}-2), 4.21(\mathrm{dd}, J=9.0,6.6 \mathrm{~Hz}, 1 \mathrm{H}, \mathrm{H}-2), 4.70(\mathrm{~d}, J=7.2$ $\mathrm{Hz}, 1 \mathrm{H}, \mathrm{H}-8 \mathrm{a}), 4.94$ (d, $J=6.6,1.0 \mathrm{~Hz}, 1 \mathrm{H}, \mathrm{H}-3), 6.27$ (d, $J$ $=1.2 \mathrm{~Hz}, 1 \mathrm{H}, \mathrm{H}-3$ ind), $7.04(\mathrm{td}, J=7.2,1.2 \mathrm{~Hz}, 1 \mathrm{H}, \mathrm{H}-5$ ind), $7.11(\mathrm{tm}, J=7.2 \mathrm{~Hz}, 1 \mathrm{H}, \mathrm{H}-6$ ind $), 7.24-7.33(\mathrm{~m}, 6 \mathrm{H}$, ArH), 7.48 (d, $J=8.1 \mathrm{~Hz}, 1 \mathrm{H}, \mathrm{H}-4$ ind), 8.62 (br s, $1 \mathrm{H}, \mathrm{NH}$ ); ${ }^{13} \mathrm{C}$ NMR $(75.4 \mathrm{MHz}) \delta 10.7\left(\mathrm{CH}_{3}\right), 25.3\left(\mathrm{CH}_{2}\right), 33.8(\mathrm{C}-6), 40.1$ (C-7), $44.2(\mathrm{C}-8), 49.0\left(\mathrm{CHCO}_{2} \mathrm{Me}\right), 52.5\left(\mathrm{CH}_{3} \mathrm{O}\right), 58.0(\mathrm{C}-3), 74.2$ (C-2), 91.3 (C-8a), 102.6 (C-3 ind), 111.1 (C-7 ind), 119.7 (C-4 ind), 120.2 (C-5 ind), 121.9 (C-6 ind), 126.7, 128.6 (C-o, $m$ ), 127.8 (C-p), 128.4 (C-3a ind), 132.0 (C-2 ind), 136.1 (C-i), 140.6 (C-7a ind), $167.1(\mathrm{NCO}), 172.5(\mathrm{COO}) ;[\alpha]^{22} \mathrm{D}-348.5$ (c 0.2, EtOH); MS-EI m/z $432\left(\mathrm{M}^{+}, 21\right), 244$ (100), 149 (25), 124 (33). HMRS calcd for $\mathrm{C}_{26} \mathrm{H}_{28} \mathrm{~N}_{2} \mathrm{O}_{4} 432.2049$, found 432.2040. 56: IR (film) $3330,1668 \mathrm{~cm}^{-1}$; ${ }^{1} \mathrm{H}$ NMR $(300 \mathrm{MHz}) \delta 1.08(\mathrm{t}, J=7.5$ $\mathrm{Hz}, 3 \mathrm{H}), 2.31$ (q, $J=7.5 \mathrm{~Hz}, 2 \mathrm{H}), 4.13(\mathrm{~m}, 1 \mathrm{H}), 4.30$ (dd, $J$ $=11.4,4.8 \mathrm{~Hz}, 1 \mathrm{H}), 6.29(\mathrm{dd}, J=7.2,4.8 \mathrm{~Hz}, 1 \mathrm{H}), 6.53(\mathrm{~d}, J$ $=9.3 \mathrm{~Hz}, 1 \mathrm{H}), 7.04(\mathrm{dm}, J=1.8 \mathrm{~Hz}, 1 \mathrm{H}), 7.22(\mathrm{dd}, J=9.3$, $2.7 \mathrm{~Hz}, 1 \mathrm{H}), 7.26-7.39(\mathrm{~m}, 5 \mathrm{H}) ;{ }^{13} \mathrm{C} \mathrm{NMR}(75.4 \mathrm{MHz}) \delta 14.7$ $\left(\mathrm{CH}_{3}\right), 24.9\left(\mathrm{CH}_{2}\right), 60.0(\mathrm{CH}), 63.2\left(\mathrm{CH}_{2}\right), 120.1(\mathrm{CH}), 121.8(\mathrm{C})$, $127.8(\mathrm{CH}), 128.8(\mathrm{CH}), 128.1(\mathrm{CH}), 132.0(\mathrm{CH}), 136.8(\mathrm{C})$, $140.7(\mathrm{CH}), 162.8(\mathrm{C})$. Anal. Calcd for $\mathrm{C}_{15} \mathrm{H}_{17} \mathrm{NO}_{2} \cdot 1{ }_{2} \mathrm{H}_{2} \mathrm{O}$ : C, 71.79; H, 7.38; N, 5.40. Found: C, 71.62; H, 7.21; N, 5.59.

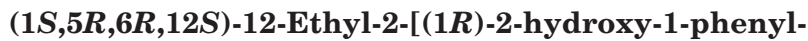
ethyl]-6-(methoxycarbonyl)-3-oxo-1,2,3,4,5,6-hexahydro1,5-methanoazocino[4,3-b]indole (12b). Operating as described for the preparation of 12a, starting from $(\alpha S)-\mathbf{1 1 b}(650$ $\mathrm{mg}, 1.5 \mathrm{mmol})$ in $\mathrm{CH}_{2} \mathrm{Cl}_{2}(30 \mathrm{~mL})$ and $\mathrm{TiCl}_{4}(500 \mu \mathrm{L}, 4.5 \mathrm{mmol})$, tetracycle 12b (225 mg, 35\%) was obtained after flash chromatography (7:3 EtOAc-hexane). Similarly, treatment of $(\alpha R)$ $11 b$ (550 mg, $1.27 \mathrm{mmol})$ in $\mathrm{CH}_{2} \mathrm{Cl}_{2}(26 \mathrm{~mL})$ with $\mathrm{TiCl}_{4}(420$ $\mu \mathrm{L}, 3.81 \mathrm{mmol})$ gave $\mathbf{1 2 b}(228 \mathrm{mg}, 51 \%)$ after flash chromatography (7:3 EtOAc-hexane). 12b: IR (KBr) 3254, 3409, 1736, $1620 \mathrm{~cm}^{-1} ;{ }^{1} \mathrm{H}$ NMR $(500 \mathrm{MHz}) \delta 0.58(\mathrm{t}, J=7.0 \mathrm{~Hz}, 3$ $\left.\mathrm{H}, \mathrm{CH}_{3}\right), 1.27\left(\mathrm{~m}, 1 \mathrm{H}, \mathrm{CH}_{2}\right), 1.35\left(\mathrm{~m}, 1 \mathrm{H}, \mathrm{CH}_{2}\right), 1.82(\mathrm{~m}, 1 \mathrm{H}$, H-12), 2.27 (d, $J=19.0 \mathrm{~Hz}, 1 \mathrm{H}, \mathrm{H}-4$ ), 2.83 (dd, $J=19.0,8.7$ $\mathrm{Hz}, 1 \mathrm{H}, \mathrm{H}-4), 2.86(\mathrm{~m}, 1 \mathrm{H}, \mathrm{H}-5), 3.84\left(\mathrm{~s}, 3 \mathrm{H}, \mathrm{CH}_{3} \mathrm{O}\right), 3.84(\mathrm{~m}$, $\left.1 \mathrm{H}, \mathrm{H}-2^{\prime}\right), 3.86\left(\mathrm{~m}, 1 \mathrm{H}, \mathrm{H}-2^{\prime}\right), 4.01(\mathrm{~d}, J=4.5 \mathrm{~Hz}, 1 \mathrm{H}, \mathrm{H}-6)$, $4.43(\mathrm{~m}, 1 \mathrm{H}, \mathrm{H}-1), 4.67$ (dd, $\left.J=6.0,2.5 \mathrm{~Hz}, 1 \mathrm{H}, \mathrm{H}-1^{\prime}\right), 4.85$ (br s, $1 \mathrm{H}, \mathrm{OH}), 7.19-7.39$ (m, $7 \mathrm{H}, \mathrm{ArH}), 7.47$ (dd, $J=8.0$, $1.0 \mathrm{~Hz}, 1 \mathrm{H}, \mathrm{H}-8$ ), 7.60 (dd, $J=8.5,2.0 \mathrm{~Hz}, 1 \mathrm{H}, \mathrm{H}-11$ ), 9.02 (br s, $1 \mathrm{H}, \mathrm{NH}) ;{ }^{13} \mathrm{C} \mathrm{NMR}(75.4 \mathrm{MHz}) \delta 11.2\left(\mathrm{CH}_{3}\right), 24.1\left(\mathrm{CH}_{2}\right)$, 32.8 (C-5), 33.1 (C-4), 42.9 (C-12), $47.8(\mathrm{C}-6), 52.6\left(\mathrm{CH}_{3} \mathrm{O}\right), 54.6$ (C-1), 64.9 (C-2'), $71.4\left(\mathrm{C}-1^{\prime}\right), 111.6$ (C-8), 114.4 (C-11b), 117.9 (C-11), 120.3 (C-10), 122.3 (C-9), 124.8 (C-11a), 127.8 (C-p), 128.4, 128.4 (C-o, m), 129.1 (C-6a), 136.5 (C-7a), 137.8 (C-i), 171.0 (NCO), 171.2 (COO); $\mathrm{mp} 176-180{ }^{\circ} \mathrm{C}\left(\mathrm{Et}_{2} \mathrm{O}\right) ;[\alpha]^{22}{ }_{\mathrm{D}}-8.8$ (c 0.5, EtOH). Anal. Calcd for $\mathrm{C}_{26} \mathrm{H}_{28} \mathrm{~N}_{2} \mathrm{O}_{4} \cdot 1 /{ }_{4} \mathrm{H}_{2} \mathrm{O}$ : C, 71.46; $\mathrm{H}, 6.57 ; \mathrm{N}, 6.41$. Found: C, 71.20; H, 6.39; N, 6.26.

(1R,5S,12R)-12-Ethyl-6-(hydroxymethyl)-3-oxo$1,2,3,4,5,6$-hexahydro-1,5-methanoazocino $[4,3-b]$ indole (13). Into a three-necked, $100 \mathrm{~mL}$ round-bottomed flask equipped with a coldfinger condenser charged with dry iceacetone were condensed $30 \mathrm{~mL}$ of $\mathrm{NH}_{3}$ at $-78{ }^{\circ} \mathrm{C}$. The temperature was raised to $-33{ }^{\circ} \mathrm{C}$, and sodium metal was added in small portions until the blue color persisted. After the mixture was stirred at $-33^{\circ} \mathrm{C}$ for $5 \mathrm{~min}$, a solution of ent$12 \mathbf{b}(250 \mathrm{mg}, 0.58 \mathrm{mmol})$ in THF ( $3 \mathrm{~mL}$ ) was added, and the mixture was stirred at $-33{ }^{\circ} \mathrm{C}$ for $3 \mathrm{~h}$. The reaction was quenched by addition of solid $\mathrm{NH}_{4} \mathrm{Cl}$ until the blue color disappeared, and the mixture was stirred at $\mathrm{rt}$ for $4 \mathrm{~h}$. The resulting residue was digested at rt with $\mathrm{CH}_{2} \mathrm{Cl}_{2}$, and the resulting suspension was filtered and concentrated. Flash chromatography (EtOAc) afforded (16S)-13 and (16R)-13 (105 $\mathrm{mg}, 64 \%, 2: 1$ ratio). (16S)-13: IR (film) 3286, 2960, 2930, 1650 $\mathrm{cm}^{-1} ;{ }^{1} \mathrm{H} \mathrm{NMR}(400 \mathrm{MHz}) \delta 1.04(\mathrm{t}, J=7.2 \mathrm{~Hz}, 3 \mathrm{H}), 1.56$ (dt,
$J=14.0,7.2 \mathrm{~Hz}, 1 \mathrm{H}), 1.67(\mathrm{dt}, J=14.0,7.2 \mathrm{~Hz}, 1 \mathrm{H}), 1.96(\mathrm{t}$, $J=7.2 \mathrm{~Hz}, 1 \mathrm{H}), 2.06(\mathrm{~d}, J=18.0 \mathrm{~Hz}, 1 \mathrm{H}), 2.39(\mathrm{~d}, J=8.4$ $\mathrm{Hz}, 1 \mathrm{H}), 2.45$ (dd, $J=18.0,8.4 \mathrm{~Hz}, 1 \mathrm{H}), 3.23(\mathrm{dt}, J=9.2,4.8$ $\mathrm{Hz}, 1 \mathrm{H}), 3.83(\mathrm{~m}, 2 \mathrm{H}), 4.45(\mathrm{t}, J=3.0 \mathrm{~Hz}, 1 \mathrm{H}), 6.73(\mathrm{~d}, J=$ $4.4 \mathrm{~Hz}, 1 \mathrm{H}), 7.06-7.10(\mathrm{~m}, 2 \mathrm{H}), 7.24(\mathrm{dd}, J=6.8,2.4 \mathrm{~Hz}, 1$ $\mathrm{H}), 7.48(\mathrm{dd}, J=6.8,2.4 \mathrm{~Hz}, 1 \mathrm{H}), 8.97(\mathrm{~s}, 1 \mathrm{H}) ;{ }^{13} \mathrm{C} \mathrm{NMR}$ $(100.6 \mathrm{MHz}) \delta 11.6\left(\mathrm{CH}_{3}\right), 23.7\left(\mathrm{CH}_{2}\right), 29.0\left(\mathrm{CH}_{2}\right), 33.5(\mathrm{CH})$, $42.3(\mathrm{CH}), 42.4(\mathrm{CH}), 46.1(\mathrm{CH}), 64.8\left(\mathrm{CH}_{2}\right), 111.2(\mathrm{CH}), 114.6$ (C), $117.0(\mathrm{CH}), 119.7(\mathrm{CH}), 121.6(\mathrm{CH}), 124.8(\mathrm{C}), 135.1(\mathrm{C})$, 136.0 (C), $173.2(\mathrm{C}) ;[\alpha]^{22}{ }_{\mathrm{D}}-152.4$ ( $\mathrm{c}$ 1.1, EtOH); MS-EI $\mathrm{m} / \mathrm{z}$ $284\left(\mathrm{M}^{+}, 47\right), 253$ (41), 208 (41), 195 (100), 180 (50); HMRS calcd for $\mathrm{C}_{17} \mathrm{H}_{20} \mathrm{~N}_{2} \mathrm{O}_{2}$ 284.1525, found 284.1521. (16R)-13: ${ }^{1} \mathrm{H}$ NMR (300 MHz, selected resonances) $\delta 1.01(\mathrm{t}, J=7.5 \mathrm{~Hz}, 3$ H), $2.08(\mathrm{~d}, J=18.3 \mathrm{~Hz}, 1 \mathrm{H}), 2.75(\mathrm{dd}, J=18.3,8.7 \mathrm{~Hz}, 1 \mathrm{H})$, $2.79(\mathrm{t}, J=6.9 \mathrm{~Hz}, 1 \mathrm{H}), 3.77(\mathrm{~m}, 2 \mathrm{H}), 4.39(\mathrm{~d}, J=0.9 \mathrm{~Hz}, 1$ $\mathrm{H}), 9.23(\mathrm{br} \mathrm{s}, 1 \mathrm{H}) ;{ }^{13} \mathrm{C}$ NMR $(75.4 \mathrm{MHz}) \delta 11.5\left(\mathrm{CH}_{3}\right), 23.5$ $\left(\mathrm{CH}_{2}\right), 32.2(\mathrm{CH}), 35.6\left(\mathrm{CH}_{2}\right), 37.5(\mathrm{CH}), 45.3(\mathrm{CH}), 46.0(\mathrm{CH})$, $64.4\left(\mathrm{CH}_{2}\right), 111.0(\mathrm{CH}), 115.0(\mathrm{C}), 116.9(\mathrm{CH}), 119.3(\mathrm{CH}), 121.4$ $(\mathrm{CH}), 124.7(\mathrm{C}), 134.9(\mathrm{C}), 136.2(\mathrm{C}), 173.8$ (C). When the reaction time was $5 \mathrm{~min}$ instead of $3 \mathrm{~h}, \mathbf{1 3}(50 \%)$ and $(1 R, 5 S, 6 S, 12 R)-12$-ethyl-6-(hydroxymethyl)-2-[(1S)-2-hydroxy-1-phenylethyl]-3-oxo-1,2,3,4,5,6-hexahydro-1,5-methanoazocino $[4,3-b]$ indole $(57,15 \%)$ were obtained after flash chromatography (EtOAc to 95:5 EtOAc-EtOH). 57: IR (film) $3305,2932,1613 \mathrm{~cm}^{-1} ;{ }^{1} \mathrm{H}$ NMR $(400 \mathrm{MHz}) \delta 0.76(\mathrm{t}, J=7.6$ $\left.\mathrm{Hz}, 3 \mathrm{H}, \mathrm{CH}_{3}\right), 1.33\left(\mathrm{~m}, 2 \mathrm{H}, \mathrm{CH}_{2}\right), 1.83(\mathrm{t}, J=7.6 \mathrm{~Hz}, 1 \mathrm{H}$, $\mathrm{H}-12), 2.28(\mathrm{~d}, J=19.2 \mathrm{~Hz}, 1 \mathrm{H}, \mathrm{H}-4), 2.39(\mathrm{dd}, J=8.4,5.2$ $\mathrm{Hz}, 1 \mathrm{H}, \mathrm{H}-5$ ), 2.63 (dd, $J=19.2,8.8 \mathrm{~Hz}, 1 \mathrm{H}, \mathrm{H}-4), 3.22$ (dt, $J=8.8,5.2 \mathrm{~Hz}, 1 \mathrm{H}, \mathrm{H}-6), 3.88\left(\mathrm{~m}, 3 \mathrm{H}, \mathrm{CH}_{2} \mathrm{OH}, \mathrm{H}-2^{\prime}\right), 4.00$ (dd, $\left.J=9.2,6.0 \mathrm{~Hz}, 1 \mathrm{H}, \mathrm{H}-2^{\prime}\right), 4.42(\mathrm{~d}, J=0.8 \mathrm{~Hz}, 1 \mathrm{H}, \mathrm{H}-1)$, $4.72\left(\mathrm{dd}, J=6.0,2.8 \mathrm{~Hz}, 1 \mathrm{H}, \mathrm{H}-1^{\prime}\right), 5.00(\mathrm{~d}, J=6.0 \mathrm{~Hz}, 1 \mathrm{H}$, $\mathrm{OH}), 7.11-7.40(\mathrm{~m}, 7 \mathrm{H}, \mathrm{ArH}), 7.49(\mathrm{dd}, J=6.8,1.6 \mathrm{~Hz}, 1 \mathrm{H}$, $\mathrm{H}-8$ ), 7.60 (dd, $J=6.8,2.0 \mathrm{~Hz}, 1 \mathrm{H}, \mathrm{H}-11$ ), 9.07 (s, $1 \mathrm{H}, \mathrm{NH}$ ); ${ }^{13} \mathrm{C}$ NMR $(75.4 \mathrm{MHz}) \delta 11.2\left(\mathrm{CH}_{3}\right), 23.9\left(\mathrm{CH}_{2}\right), 30.7(\mathrm{C}-4), 32.9$ (C-5), 42.4 (C-6), 43.5 (C-12), 55.3 (C-1), $64.7\left(\mathrm{CH}_{2} \mathrm{OH}\right), 64.9$ (C-2'), 71.2 (C-1'), 111.4 (C-8), 112.7 (C-11b), 117.6 (C-11), 120.1 (C-10), 121.7 (C-9), 124.8 (C-11a), 127.8 (C-p), 128.3, 128.5 (C$o, m) ; 136.0$ (C-6a), 136.2 (C-7a), 137.7 (C-i), 171.5 (NCO); $[\alpha]^{22}$ -6.1 ( $c$ 0.56, EtOH); MS-EI m/z $404\left(\mathrm{M}^{+}, 30\right), 373$ (35), 284 (30), 268 (63), 196 (100), 168 (86); HMRS calcd for $\mathrm{C}_{25} \mathrm{H}_{28} \mathrm{~N}_{2} \mathrm{O}_{3}$ 404.2100, found 404.2099.

$(1 R, 5 S, 12 R)$-12-Ethyl-6-methylene-3-oxo-1,2,3,4,5,6hexahydro-1,5-methanoazocino $[4,3-b]$ indole (14). Mesyl chloride $(43 \mu \mathrm{L}, 0.55 \mathrm{mmol})$ and $\mathrm{Et}_{3} \mathrm{~N}(91 \mu \mathrm{L}, 0.66 \mathrm{mmol})$ were added to a cooled $\left(0{ }^{\circ} \mathrm{C}\right)$ solution of $13(107 \mathrm{mg}, 0.37 \mathrm{mmol})$ in $\mathrm{CH}_{2} \mathrm{Cl}_{2}(18 \mathrm{~mL})$. The mixture was stirred at $0{ }^{\circ} \mathrm{C}$ for $2 \mathrm{~h}$, diluted with $\mathrm{CH}_{2} \mathrm{Cl}_{2}$, dried, and concentrated to give the mesylate derivative (150 mg), which was used without further purification in the next step. DBU $(60 \mu \mathrm{L}, 0.4 \mathrm{mmol})$ was added to a solution of the mesylate $(150 \mathrm{mg})$ in THF $(2 \mathrm{~mL})$, and the mixture was heated at reflux for $24 \mathrm{~h}$. Additional DBU (60 $\mu \mathrm{L}, 0.4 \mathrm{mmol}$ ) was added, and the mixture was heated at reflux for $24 \mathrm{~h}$. The mixture was concentrated, and the residue was taken up in EtOAc and washed with cool aqueous $\mathrm{H}_{2} \mathrm{SO}_{4}$. The aqueous layer was extracted with EtOAc, and the combined organic extracts were dried and concentrated to give an oil. Flash chromatography (95:5 EtOAc-EtOH) gave $14(53.1 \mathrm{mg}$, $53 \%):{ }^{1} \mathrm{H}$ NMR $(400 \mathrm{MHz}) \delta 1.07\left(\mathrm{t}, J=7.2 \mathrm{~Hz}, 3 \mathrm{H}, \mathrm{CH}_{3}\right)$, $1.64\left(\mathrm{~m}, 1 \mathrm{H}, \mathrm{CH}_{2}\right), 1.72\left(\mathrm{~m}, 1 \mathrm{H}, \mathrm{CH}_{2}\right), 2.12(\mathrm{t}, J=7.2 \mathrm{~Hz}, 1$ $\mathrm{H}, \mathrm{H}-12), 2.27(\mathrm{~d}, J=18.8 \mathrm{~Hz}, 1 \mathrm{H}, \mathrm{H}-4), 2.86(\mathrm{dd}, J=18.8$, $8.0 \mathrm{~Hz}, 1 \mathrm{H}, \mathrm{H}-4), 2.98(\mathrm{~d}, J=8.0 \mathrm{~Hz}, 1 \mathrm{H}, \mathrm{H}-5), 4.52(\mathrm{~m}, 1 \mathrm{H}$, $\mathrm{H}-1), 5.01\left(\mathrm{~s}, 1 \mathrm{H}, \mathrm{CH}_{2}=\right), 5.15\left(\mathrm{~s}, 1 \mathrm{H}, \mathrm{CH}_{2}=\right), 6.58(\mathrm{br} \mathrm{s}, 1 \mathrm{H}$, $\mathrm{NH}), 7.10(\mathrm{td}, J=8.0,0.8 \mathrm{~Hz}, 1 \mathrm{H}, \mathrm{H}-10), 7.19(\mathrm{td}, J=8.0$, $1.2 \mathrm{~Hz}, 1 \mathrm{H}, \mathrm{H}-9), 7.29(\mathrm{~d}, J=8.4 \mathrm{~Hz}, 1 \mathrm{H}, \mathrm{H}-8), 7.49(\mathrm{~d}, J=$ $7.6 \mathrm{~Hz}, 1 \mathrm{H}, \mathrm{H}-11), 8.23(\mathrm{~s}, 1 \mathrm{H}, \mathrm{NH}) ;{ }^{13} \mathrm{C} \mathrm{NMR}(100.6 \mathrm{MHz}) \delta$ $11.5\left(\mathrm{CH}_{3}\right), 23.5\left(\mathrm{CH}_{2}\right), 36.1(\mathrm{C}-4), 39.3(\mathrm{C}-5), 42.0(\mathrm{C}-12), 46.5$ (C-1), $105.3\left(\mathrm{CH}_{2}=\right), 111.2$ (C-8), 118.1 (C-11), 119.5 (C-11b), 120.2 (C-10), 123.6 (C-9), 125.2 (C-11a), 131.5 (C-6a), 136.7 (C-7a), 141.7 (C-6), $172.5(\mathrm{NCO}) ;[\alpha]^{22}{ }_{\mathrm{D}}+87.1$ (c 0.4, EtOH).

General Procedure for Conjugate Addition Reactions. $n$-BuLi (1.6 M solution in hexanes) or LDA (1.5 M solution in cyclohexane, $1.5-5 \mathrm{mmol})$ and HMPA (0-2 mmol) were added 
to a cooled solution $\left(-78^{\circ} \mathrm{C}\right)$ of the dithioacetal $(\mathbf{1 5}-\mathbf{1 9} ; 1.5-5$ $\mathrm{mmol}$ ) in THF. After the mixture was stirred at $-78^{\circ} \mathrm{C}$ for 1 $\mathrm{h}$, a solution of the unsaturated lactam trans-2, cis-2, or $\mathbf{1 0}$ (1 mmol) in THF was added via cannula, and the mixture was stirred at the temperature for the reaction time indicated in Table 1 . The resulting mixture was poured into saturated $\mathrm{NH}_{4} \mathrm{Cl}$ and extracted with EtOAc. The combined organic extracts were dried and concentrated, and the resulting residue was chromatographed to afford 21-33 (see the Supporting Information for details).

[3R,7S(and 7R),8S,8aR]-8-Ethyl-7-[2-(2-indolyl)-1,3dithian-2-yl]-5-oxo-3-phenyl-2,3,6,7,8,8a-hexahydro-5Hoxazolo[3,2-a]pyridine (34a and 34b). $n$-BuLi $(15.4 \mathrm{~mL}$ of a $1.6 \mathrm{M}$ solution in cyclohexane, $22.6 \mathrm{mmol}$ ) was added to a cooled solution $\left(-78^{\circ} \mathrm{C}\right)$ of 2 -(2-indolyl)-1,3-dithiane ${ }^{28}(\mathbf{2 0} ; 2.9$ $\mathrm{g}, 12.3 \mathrm{mmol})$ in THF $(40 \mathrm{~mL})$. The mixture was stirred at $-30{ }^{\circ} \mathrm{C}$ for $2 \mathrm{~h}$ and added to a cooled solution $\left(-78^{\circ} \mathrm{C}\right)$ of $\mathbf{1 0}$ $(600 \mathrm{mg}, 2.46 \mathrm{mmol})$ in $\mathrm{THF}(10 \mathrm{~mL})$. The resulting mixture was stirred at $0{ }^{\circ} \mathrm{C}$ for $20 \mathrm{~h}$, poured into saturated aqueous $\mathrm{NH}_{4} \mathrm{Cl}$, and extracted with EtOAc. The combined organic extracts were dried and concentrated to give and oil. Flash chromatography (2:8 to 7:3 EtOAc-hexane) afforded 34a (843 $\mathrm{mg}, 72 \%)$ and 34b (207 mg, 18\%). 34a: IR (film) 3280, 1650 $\mathrm{cm}^{-1}$; ${ }^{1} \mathrm{H}$ NMR $(300 \mathrm{MHz}) \delta 0.87\left(\mathrm{t}, J=7.2 \mathrm{~Hz}, 3 \mathrm{H}, \mathrm{CH}_{3}\right)$, $1.26\left(\mathrm{~m}, 1 \mathrm{H}, \mathrm{CH}_{2}\right), 1.58\left(\mathrm{~m}, 1 \mathrm{H}, \mathrm{CH}_{2}\right), 1.86\left[\mathrm{~m}, 2 \mathrm{H}, \mathrm{CH}_{2}\right.$ $\left.\left(\mathrm{CH}_{2} \mathrm{~S}\right)_{2}\right], 2.03(\mathrm{~m}, 1 \mathrm{H}, \mathrm{H}-8), 2.64\left(\mathrm{~m}, 3 \mathrm{H}, \mathrm{H}-6, \mathrm{CH}_{2} \mathrm{~S}\right), 2.79$ (m, $1 \mathrm{H}, \mathrm{H}-7), 2.88$ (masked, $\left.2 \mathrm{H}, \mathrm{CH}_{2} \mathrm{~S}\right), 2.90(\mathrm{dd}, J=15.6$, $6.0 \mathrm{~Hz}, 1 \mathrm{H}, \mathrm{H}-6$ ), 3.95 (dd, $J=9.0,1.5 \mathrm{~Hz}, 1 \mathrm{H}, \mathrm{H}-2$ ), 4.13 $(\mathrm{dd}, J=9.0,7.2 \mathrm{~Hz}, 1 \mathrm{H}, \mathrm{H}-2), 4.80$ (dd, $J=7.2,1.5 \mathrm{~Hz}, 1 \mathrm{H}$, $\mathrm{H}-3), 4.85$ (d, $J=6.6 \mathrm{~Hz}, 1 \mathrm{H}, \mathrm{H}-8 \mathrm{a}), 6.84(\mathrm{dd}, J=2.4,1.2 \mathrm{~Hz}$, $1 \mathrm{H}, \mathrm{H}-3$ ind), 7.13 (td, $J=7.2,1.2 \mathrm{~Hz}, 1 \mathrm{H}, \mathrm{H}-5$ ind), $7.19-$ $7.27(\mathrm{~m}, 7 \mathrm{H}, \mathrm{ArH}), 7.38$ (dd, $J=8.1,1.2 \mathrm{~Hz}, 1 \mathrm{H}, \mathrm{H}-7$ ind), $7.59(\mathrm{~d}, J=7.2 \mathrm{~Hz}, 1 \mathrm{H}, \mathrm{H}-4$ ind $), 8.57(\mathrm{br} \mathrm{s}, 1 \mathrm{H}, \mathrm{NH}) ;{ }^{13} \mathrm{C}$ $\operatorname{NMR}(75.4 \mathrm{MHz}) \delta 12.5\left(\mathrm{CH}_{3}\right), 21.0\left(\mathrm{CH}_{2}\right), 24.2\left[\mathrm{CH}_{2}\left(\mathrm{CH}_{2} \mathrm{~S}\right)_{2}\right]$, $27.9,28.5\left(\mathrm{CH}_{2} \mathrm{~S}\right), 35.3(\mathrm{C}-6), 44.8(\mathrm{C}-8), 46.9(\mathrm{C}-7), 57.5\left(\mathrm{CS}_{2}\right)$, 58.5 (C-3), 74.0 (C-2), 91.0 (C-8a), 106.4 (C-3 ind), 111.1 (C-7 ind), 120.0 (C-4 ind), 120.6 (C-5 ind), 122.4 (C-6 ind), 126.3, 128.4 (C-o, $m$ ), 127.1 (C-p), 128.4 (C-3a ind), 136.0 (C-2 ind), $136.9(\mathrm{C}-i), 141.3$ (C-7a ind), $167.5(\mathrm{NCO}) ;[\alpha]^{22}{ }_{\mathrm{D}}+17.1(c 0.5$, $\mathrm{MeOH}$ ). Anal. Calcd for $\mathrm{C}_{27} \mathrm{H}_{33} \mathrm{~N}_{2} \mathrm{~S}_{2} \mathrm{O}_{2} \cdot 1{ }_{2} \mathrm{H}_{2} \mathrm{O}$ : C, 66.50; H, 6.41; N, 5.74. Found: C, 66.63; H, 6.38; N, 5.87. 34b: ${ }^{1} \mathrm{H}$ NMR $(300 \mathrm{MHz}) \delta 0.88\left(\mathrm{t}, J=7.5 \mathrm{~Hz}, 3 \mathrm{H}, \mathrm{CH}_{3}\right), 1.19\left(\mathrm{~m}, 1 \mathrm{H}, \mathrm{CH}_{2}\right)$, $1.40\left(\mathrm{~m}, 1 \mathrm{H}, \mathrm{CH}_{2}\right), 1.78\left[\mathrm{~m}, 2 \mathrm{H}, \mathrm{CH}_{2}\left(\mathrm{CH}_{2} \mathrm{~S}\right)_{2}\right], 2.23(\mathrm{~m}, 2 \mathrm{H}$, $\mathrm{H}-6, \mathrm{H}-7), 2.53\left(\mathrm{~m}, 5 \mathrm{H}, \mathrm{CH}_{2} \mathrm{~S}, \mathrm{H}-8\right), 2.87(\mathrm{~d}, J=15.3 \mathrm{~Hz}, 1 \mathrm{H}$, H-6), 4.16 (dd, $J=9.3,2.1 \mathrm{~Hz}, 1 \mathrm{H}, \mathrm{H}-2$ ), 4.21 (dd, $J=9.3,5.7$ $\mathrm{Hz}, 1 \mathrm{H}, \mathrm{H}-2), 4.67$ (d, $J=9.0 \mathrm{~Hz}, 1 \mathrm{H}, \mathrm{H}-8 \mathrm{a}), 4.96$ (dd, $J=$ $5.7,2.1 \mathrm{~Hz}, 1 \mathrm{H}, \mathrm{H}-3), 6.81$ (dd, $J=2.1,0.9 \mathrm{~Hz}, 1 \mathrm{H}, \mathrm{H}-3$ ind), $7.09(\mathrm{td}, J=7.2,1.2 \mathrm{~Hz}, 1 \mathrm{H}, \mathrm{H}-5$ ind $), 7.16(\mathrm{td}, J=7.2,1.5$ $\mathrm{Hz}, 1 \mathrm{H}, \mathrm{H}-6$ ind), 7.22-7.32 (m, $6 \mathrm{H}, \mathrm{ArH}$ ), 7.50 (dd, $J=7.8$, $0.9 \mathrm{~Hz}, 1 \mathrm{H}, \mathrm{H}-7$ ind $), 7.57$ (d, $J=7.5 \mathrm{~Hz}, 1 \mathrm{H}, \mathrm{H}-4$ ind $), 8.71$ (br s, $1 \mathrm{H}, \mathrm{NH}) ;{ }^{13} \mathrm{C} \mathrm{NMR}(75.4 \mathrm{MHz}) \delta 10.3\left(\mathrm{CH}_{3}\right), 24.1\left[\mathrm{CH}_{2}-\right.$ $\left.\left(\mathrm{CH}_{2} \mathrm{~S}\right)_{2}\right], 26.5\left(\mathrm{CH}_{2}\right), 27.5,27.6\left(\mathrm{CH}_{2} \mathrm{~S}\right), 34.3(\mathrm{C}-6), 41.6(\mathrm{C}-8)$, 48.2 (C-7), 58.1 (C-3), $60.9\left(\mathrm{CS}_{2}\right), 74.4$ (C-2), 90.7 (C-8a), 105.5 (C-3 ind), 111.1 (C-7 ind), 119.7 (C-4 ind), 120.3 (C-5 ind), 121.9 (C-6 ind), 127.4 (C-p), 127.4, 127.9 (C-o, $m$ ), 128.5 (C-3a ind), 135.9 (C-2 ind), 137.5 (C-i), 140.0 (C-7a ind), 167.5 (NCO); $[\alpha]^{22}{ }_{\mathrm{D}}+99.3(c 0.5, \mathrm{MeOH})$. Anal. Calcd for $\mathrm{C}_{27} \mathrm{H}_{33} \mathrm{~N}_{2} \mathrm{~S}_{2} \mathrm{O}_{2}$ : C, $67.71 ; \mathrm{H}, 6.32$; N, 5.85. Found: C, 67.71; H, 6.62; N, 5.62.

General Procedure for Desulfurization Reactions. $\mathrm{NiCl}_{2} \cdot 6 \mathrm{H}_{2} \mathrm{O}(7-10 \mathrm{mmol})$ was added to a cooled solution $(0$ ${ }^{\circ} \mathrm{C}$ ) of the dithioacetal $(1 \mathrm{mmol})$ in $1: 3 \mathrm{THF}-\mathrm{MeOH}$ (ca. 50 $\mathrm{mL})$. When the dissolution was complete, $\mathrm{NaBH}_{4}(21-30$ mmol) was added portionwise, and the mixture was stirred at $0-25{ }^{\circ} \mathrm{C}$ for $1-8 \mathrm{~h}$ and filtered through Celite. The filtrate was concentrated and partitioned between saturated aqueous $\mathrm{NaCl}$ and $\mathrm{CH}_{2} \mathrm{Cl}_{2}$. The combined organic extracts were dried and concentrated to give the desired product 35-42 (see the Supporting Information for details).

$(3 R, 7 S, 8 S, 8 a R)-8-E t h y l-7-(2-i n d o l y l m e t h y l)-5-o x o-3-$ phenyl-2,3,6,7,8,8a-hexahydro-5H-oxazolo[3,2-a $]$ pyri-

(28) Rubiralta, M.; Casamitjana, N.; Grierson, D. S.; Husson, H.-P. Tetrahedron 1988, 44, 443. dine (50). Following the above general procedure, from dithioacetal 34a $(150 \mathrm{mg}, 0.31 \mathrm{mmol})$ in $1: 3 \mathrm{THF}-\mathrm{MeOH}(10$ $\mathrm{mL}$ ), $\mathrm{NiCl}_{2} \cdot 6 \mathrm{H}_{2} \mathrm{O}$ (745 mg, $\left.3.1 \mathrm{mmol}\right)$, and $\mathrm{NaBH}_{4}(356 \mathrm{mg}$, $9.4 \mathrm{mmol}$ ) at $0{ }^{\circ} \mathrm{C}$ for $2 \mathrm{~h}$ was obtained compound $\mathbf{5 0}(70 \mathrm{mg}$, $60 \%)$ after flash chromatography (3:7 EtOAc-hexane): IR (film) $1640 \mathrm{~cm}^{-1},{ }_{1}^{1} \mathrm{H}$ NMR $(300 \mathrm{MHz}) \delta 1.10(\mathrm{t}, J=7.5 \mathrm{~Hz}, 3$ $\left.\mathrm{H}, \mathrm{CH}_{3}\right), 1.57\left(\mathrm{~m}, 1 \mathrm{H}, \mathrm{CH}_{2}\right), 1.94\left(\mathrm{~m}, 2 \mathrm{H}, \mathrm{CH}_{2}, \mathrm{H}-8\right), 2.26$ (dd, $J=18.3,5.5 \mathrm{~Hz}, 1 \mathrm{H}, \mathrm{H}-6), 2.30-2.50\left(\mathrm{~m}, 3 \mathrm{H}, \mathrm{H}-6, \mathrm{H}-7, \mathrm{CH}_{2^{-}}\right.$ In), 2.96 (d, $J=12.3 \mathrm{~Hz}, 1 \mathrm{H}, \mathrm{CH}_{2} \mathrm{In}$ ), 4.00 (dd, $J=9.0,1.0$ $\mathrm{Hz}, 1 \mathrm{H}, \mathrm{H}-2), 4.12$ (dd, $J=9.0,7.0 \mathrm{~Hz}, 1 \mathrm{H}, \mathrm{H}-2), 4.64(\mathrm{~d}, J$ $=9.3 \mathrm{~Hz}, 1 \mathrm{H}, \mathrm{H}-8 \mathrm{a}), 4.90$ (br d, $J=6.0 \mathrm{~Hz}, 1 \mathrm{H}, \mathrm{H}-3), 6.22(\mathrm{~d}$, $J=2.1 \mathrm{~Hz}, 1 \mathrm{H}, \mathrm{H}-3$ ind $), 7.06(\mathrm{~m}, 3 \mathrm{H}, \mathrm{ArH}), 7.25(\mathrm{~m}, 5 \mathrm{H}$, $\mathrm{ArH}), 7.49$ (m, $1 \mathrm{H}, \mathrm{ArH}), 8.62(\mathrm{br} \mathrm{s}, 1 \mathrm{H}, \mathrm{NH}) ;{ }^{13} \mathrm{C} \mathrm{NMR}(75.4$ $\mathrm{MHz}) \delta 11.4\left(\mathrm{CH}_{3}\right), 21.1\left(\mathrm{CH}_{2}\right), 27.1\left(\mathrm{CH}_{2} \mathrm{In}\right), 34.1(\mathrm{C}-7), 37.0$ (C-6), 43.8 (C-8), 59.4 (C-3), 73.8 (C-2), $90.0(\mathrm{C}-8 \mathrm{a}), 100.4(\mathrm{C}-3$ ind), $110.6(\mathrm{C}-7$ ind $), 119.5(\mathrm{CH}), 119.6(\mathrm{C}-4 \mathrm{ind}), 121.0(\mathrm{CH})$, 126.2 (CH), $127.5(\mathrm{CH}), 128.5(\mathrm{CH}), 128.6(\mathrm{C}-3 \mathrm{a}$ ind), 135.9 (C-2 ind), $137.0(\mathrm{C}-i), 141.3$ (C-7a ind), $167.0(\mathrm{NCO}) ;[\alpha]^{22} \mathrm{D}$ +13.8 ( c 0.55, MeOH). Anal. Calcd for $\mathrm{C}_{24} \mathrm{H}_{26} \mathrm{~N}_{2} \mathrm{O}_{2} \cdot 1 /{ }_{2} \mathrm{H}_{2} \mathrm{O}: \mathrm{C}$, 70.58; H, 6.53; N, 6.72. Found: C, 70.66; H, 6.59; N, 6.67.

$(1 R, 5 S, 12 S)-12-E t h y l-2-[(1 R)-2-h y d r o x y-1-p h e n y l e t h y l]-$ 3,6-dioxo-1,2,3,4,5,6-hexahydro-1,5-methanoazocino[4,3b]indole (51). $\mathrm{TiCl}_{4}(70 \mu \mathrm{L}, 0.62 \mathrm{mmol})$ was added to a solution of dithioacetal 34a $(100 \mathrm{mg}, 0.2 \mathrm{mmol})$ in $\mathrm{CH}_{2} \mathrm{Cl}_{2}(5$ $\mathrm{mL}$ ), and the resulting mixture was heated at reflux $6 \mathrm{~h}$, poured into saturated solution $\mathrm{NaHCO}_{3}$, and extracted with $\mathrm{CH}_{2} \mathrm{Cl}_{2}$. The combined organic extracts were dried and concentrated, and the resulting residue was chromatographed (EtOAc) to afford tetracycle $\mathbf{5 1}(16 \mathrm{mg}, 20 \%)$ and starting material $(22 \mathrm{mg}) .51$ : IR (film) 1652, $1640 \mathrm{~cm}^{-1}$; ${ }^{1} \mathrm{H}$ NMR (400 $\mathrm{MHz}) \delta 0.64\left(\mathrm{t}, J=7.2 \mathrm{~Hz}, 3 \mathrm{H}, \mathrm{CH}_{3}\right), 1.06\left(\mathrm{~m}, 1 \mathrm{H}, \mathrm{CH}_{2}\right), 1.25$ $\left(\mathrm{m}, 1 \mathrm{H}, \mathrm{CH}_{2}\right), 2.40(\mathrm{~m}, 1 \mathrm{H}, \mathrm{H}-12), 2.85(\mathrm{~d}, J=19.0 \mathrm{~Hz}, 1 \mathrm{H}$, $\mathrm{H}-4), 2.99(\mathrm{dm}, J=8.5 \mathrm{~Hz}, 1 \mathrm{H}, \mathrm{H}-5), 3.15$ (dd, $J=18.8,8.6$ $\mathrm{Hz}, 1 \mathrm{H}, \mathrm{H}-4), 4.10\left(\mathrm{~m}, 1 \mathrm{H}, \mathrm{H}-2^{\prime}\right), 4.24(\mathrm{dd}, J=10.5,4.2 \mathrm{~Hz}$, $\left.1 \mathrm{H}, \mathrm{H}-2^{\prime}\right), 4.49$ (m, $\left.1 \mathrm{H}, \mathrm{H}-1\right), 5.86(\mathrm{dd}, J=8.0,4.2 \mathrm{~Hz}, 1 \mathrm{H}$, H-1'), 7.13-7.32 (m, $8 \mathrm{H}, \mathrm{ArH}), 7.51$ (dd, $J=11.2,1.2 \mathrm{~Hz}, 1$ $\mathrm{H}, \mathrm{ArH}), 9.20(\mathrm{br} \mathrm{s}, 1 \mathrm{H}, \mathrm{NH}) ;{ }^{13} \mathrm{C} \mathrm{NMR}(100.6 \mathrm{MHz}) \delta 11.5$ $\left(\mathrm{CH}_{3}\right), 23.9\left(\mathrm{CH}_{2}\right), 36.1(\mathrm{C}-4), 45.9(\mathrm{C}-5), 48.3(\mathrm{C}-12), 49.6$ (C-1), 61.5 (C-1'), 63.2 (C-2'), 113.1 (C-8), $120.6(\mathrm{CH}), 121.5$ $(\mathrm{CH}), 124.8(\mathrm{C}-11 \mathrm{~b}), 127.0(\mathrm{C}-11 \mathrm{a}), 127.4(\mathrm{CH}), 127.7(\mathrm{CH})$, $128.0(\mathrm{CH}), 128.9(\mathrm{CH}), 129.1$ (C-6a), 136.2 (C-7a), 138.0 (C-i), $170.6(\mathrm{NCO}), 191.4(\mathrm{CO})$. Anal. Calcd for $\mathrm{C}_{24} \mathrm{H}_{24} \mathrm{~N}_{2} \mathrm{O}_{3}$. $\mathrm{H}_{2} \mathrm{O}:$ C, $70.92 ; \mathrm{H}, 6.45 ; \mathrm{N}, 6.89$. Found: C, 70.72; H, 6.20; N, 6.58 .

$(1 R, 5 S, 12 S)-12-E$ thyl-2-[(1R)-2-hydroxy-1-phenylethyl]3-oxo-1,2,3,4,5,6-hexahydro-1,5-methanoazocino[4,3-b]indole (52). Operating as described above, from $\mathrm{TiCl}_{4}(75 \mu \mathrm{L}$, $0.68 \mathrm{mmol})$ and $\mathbf{5 0}(85 \mathrm{mg}, 0.23 \mathrm{mmol})$ in $\mathrm{CH}_{2} \mathrm{Cl}_{2}(7 \mathrm{~mL})$ for 7 $\mathrm{h}$ were obtained tetracycle $\mathbf{5 2}(15 \mathrm{mg}, 17 \%)$ and starting material (10 mg) after flash chromatography (EtOAc). 52: IR (film) $1670 \mathrm{~cm}^{-1} ;{ }^{1} \mathrm{H}$ NMR $(400 \mathrm{MHz}) \delta 0.63(\mathrm{t}, J=7.2 \mathrm{~Hz}, 3$ $\left.\mathrm{H}, \mathrm{CH}_{3}\right), 0.98\left(\mathrm{~m}, 1 \mathrm{H}, \mathrm{CH}_{2}\right), 1.12\left(\mathrm{~m}, 1 \mathrm{H}, \mathrm{CH}_{2}\right), 2.02(\mathrm{~m}, 1 \mathrm{H}$, H-12), 2.48 (d, J = $19.0 \mathrm{~Hz}, 1 \mathrm{H}, \mathrm{H}-4), 2.55$ (m, $1 \mathrm{H}, \mathrm{H}-5), 2.62$ $(\mathrm{d}, J=17.2 \mathrm{~Hz}, 1 \mathrm{H}, \mathrm{H}-6), 2.97(\mathrm{dd}, J=17.2,5.6 \mathrm{~Hz}, 1 \mathrm{H}$, H-6), 3.08 (dd, $J=19.0,8.4 \mathrm{~Hz}, 1 \mathrm{H}, \mathrm{H}-4), 4.18-4.30$ (m, $3 \mathrm{H}$, $\left.\mathrm{H}-2^{\prime}, \mathrm{H}-1\right), 5.74\left(\mathrm{dd}, J=8.0,5.6 \mathrm{~Hz}, 1 \mathrm{H}, \mathrm{H}-1^{\prime}\right), 7.00-7.40(\mathrm{~m}$, $9 \mathrm{H}, \mathrm{ArH}), 8.10$ (br s, $1 \mathrm{H}, \mathrm{NH}) ;{ }^{13} \mathrm{C} \mathrm{NMR}(100.6 \mathrm{MHz}) \delta 11.7$ $\left(\mathrm{CH}_{3}\right), 22.6\left(\mathrm{CH}_{2}\right), 28.2(\mathrm{C}-6), 29.0(\mathrm{C}-5), 40.6(\mathrm{C}-4), 43.4$ (C-12), 49.8 (C-1), 62.0 (C-1'), 63.5 (C-2'), 110.8 (C-8), 117.5 $(\mathrm{CH}), 119.7(\mathrm{CH}), 121.6(\mathrm{CH}), 126.4(\mathrm{C}), 127.7(\mathrm{CH}), 127.8$ $(\mathrm{CH}), 127.9(\mathrm{CH}), 128.7(\mathrm{C}), 132.5(\mathrm{C}), 136.1(\mathrm{C}-7 \mathrm{a}), 136.6$ (C-i), 173.0 (NCO); MS-EI m/z $374\left(\mathrm{M}^{+}, 4\right), 343$ (7), 238 (16), 195 (96), 180 (100); HMRS calcd for $\mathrm{C}_{24} \mathrm{H}_{26} \mathrm{~N}_{2} \mathrm{O}_{2}$ 374.1994, found 374.1986 .

$(1 R, 5 S, 12 S)-12$-Ethyl-3-oxo-1,2,3,4,5,6-hexahydro-1,5methanoazocino[4,3-b]indole (53). Operating as described for the preparation of $\mathbf{1 3}$, from liquid $\mathrm{NH}_{3}(30 \mathrm{~mL})$, sodium, and 34a $(300 \mathrm{mg}, 0.62 \mathrm{mmol})$ in THF $(8 \mathrm{~mL})$ at $-33{ }^{\circ} \mathrm{C}$ for 25 min was obtained an intermediate 6 -hydroxylactam $(200 \mathrm{mg}$, 94\%) as an oil, which was used without further purification in the next reaction. $\mathrm{TiCl}_{4}(103 \mu \mathrm{L}, 0.94 \mathrm{mmol})$ was added to a cooled $\left(0{ }^{\circ} \mathrm{C}\right)$ solution of the oil in $\mathrm{CH}_{2} \mathrm{Cl}_{2}(150 \mathrm{~mL})$, and the 
mixture was stirred at rt for $1 \mathrm{~h}$, poured into saturated aqueous $\mathrm{NaHCO}_{3}$, and extracted with $\mathrm{CH}_{2} \mathrm{Cl}_{2}$. The combined organic extracts were dried and concentrated, and the resulting residue was chromatographed $\left(99: 1 \mathrm{CH}_{2} \mathrm{Cl}_{2}-\mathrm{MeOH}\right)$ to give tetracycles $53(55 \mathrm{mg}, 35 \%)$ and $\mathbf{5 4}(10 \mathrm{mg}, 6 \%)$. 53: IR (film) $3256,1650 \mathrm{~cm}^{-1}$; ${ }^{1} \mathrm{H}$ NMR $(400 \mathrm{MHz}) \delta 0.96(\mathrm{t}, J=7.5$ $\left.\mathrm{Hz}, 3 \mathrm{H}, \mathrm{CH}_{3}\right), 1.36\left(\mathrm{~m}, 2 \mathrm{H}, \mathrm{CH}_{2}\right), 2.24(\mathrm{~m}, 1 \mathrm{H}, \mathrm{H}-12), 2.25$ $(\mathrm{d}, J=18.4 \mathrm{~Hz}, 1 \mathrm{H}, \mathrm{H}-4), 2.52$ (dd, $J=17.2,1.2 \mathrm{~Hz}, 1 \mathrm{H}$, H-6), 2.56 (m, $1 \mathrm{H}, \mathrm{H}-5$ ), 2.86 (dd, $J=18.4,8.4 \mathrm{~Hz}, 1 \mathrm{H}, \mathrm{H}-4$ ), 3.06 (dd, $J=17.2,6.0 \mathrm{~Hz}, 1 \mathrm{H}, \mathrm{H}-6), 4.43$ (m, $1 \mathrm{H}, \mathrm{H}-1), 6.79$ (br s, $1 \mathrm{H}, \mathrm{NH}), 7.07-7.15$ (m, $2 \mathrm{H}, \mathrm{H}-9, \mathrm{H}-10), 7.28$ (d, $J=$ $6.0 \mathrm{~Hz}, 1 \mathrm{H}, \mathrm{H}-8), 7.45$ (d, $J=7.6 \mathrm{~Hz}, 1 \mathrm{H}, \mathrm{H}-11), 7.85$ (br s, $1 \mathrm{H}, \mathrm{NH}) ;{ }^{13} \mathrm{C} \mathrm{NMR}(100.6 \mathrm{MHz}) \delta 12.1\left(\mathrm{CH}_{3}\right), 22.8\left(\mathrm{CH}_{2}\right), 27.5$ (C-6), 29.2 (C-5), 39.7 (C-4), 41.4 (C-12), 46.6 (C-1), 110.7 (C-8), 112.3 (C-11b), 117.0 (C-9), 119.7 (C-11), 121.5 (C-10), 126.2 (C-11a), 130.9 (C-6a), 136.0 (C-7a), $173.5(\mathrm{NCO}) ;[\alpha]^{22} \mathrm{D}$ -82.2 ( $c$ 0.3, $\mathrm{CHCl}_{3}$ ); MS-EI m/z $254\left(\mathrm{M}^{+}, 75\right), 195$ (76), 180 (100), 168 (51); HMRS calcd for $\mathrm{C}_{16} \mathrm{H}_{18} \mathrm{~N}_{2} \mathrm{O}$ 254.1419, found 254.1457. 54: IR (film) $1667 \mathrm{~cm}^{-1}$; ${ }^{1} \mathrm{H}$ NMR (400 MHz) $\delta 1.05$ $\left(\mathrm{t}, J=7.5 \mathrm{~Hz}, 3 \mathrm{H}, \mathrm{CH}_{3}\right), 1.57\left(\mathrm{~m}, 2 \mathrm{H}, \mathrm{CH}_{2}\right), 2.35(\mathrm{~m}, 1 \mathrm{H}$, H-12), 2.44 (d, $J=18.4 \mathrm{~Hz}, 1 \mathrm{H}, \mathrm{H}-4), 2.58$ (m, $1 \mathrm{H}, \mathrm{H}-5), 2.84$ (dd, $J=18.4,7.2 \mathrm{~Hz}, 1 \mathrm{H}, \mathrm{H}-4), 2.90(\mathrm{~d}, J=17.6 \mathrm{~Hz}, 1 \mathrm{H}$, H-6), 3.31 (dd, $J=17.6,6.4 \mathrm{~Hz}, 1 \mathrm{H}, \mathrm{H}-6), 5.52$ (br s, $1 \mathrm{H}$, $\mathrm{H}-1$ ), 6.28 (br s, $1 \mathrm{H}, \mathrm{H}-7), 6.63$ (br s, 1H, NH), 7.09-7.18 (m, $2 \mathrm{H}, \mathrm{H}-8, \mathrm{H}-9), 7.27$ (d, $J=8.4 \mathrm{~Hz}, 1 \mathrm{H}, \mathrm{H}-11), 7.51$ (d, $J=7.6$ $\mathrm{Hz}, 1 \mathrm{H}, \mathrm{H}-10) ;{ }^{13} \mathrm{C} \mathrm{NMR}(75.4 \mathrm{MHz}) \delta 11.6\left(\mathrm{CH}_{3}\right), 22.2\left(\mathrm{CH}_{2}\right)$, 26.5 (C-6), 27.2 (C-5), 39.1 (C-4), 39.9 (C-12), 60.2 (C-1), 101.5 (C-7), 108.3 (C-11), 119.8 (C-10), 120.2 (C-8), 120.6 (C-9), 129.2 (C-6a), 131.2 (C-11a), 135.5 (C-7a), 171.9 (NCO); $[\alpha]^{22}{ }_{\mathrm{D}}-105.8$ (c 2.0, $\mathrm{CHCl}_{3}$ ); MS-EI m/z $254\left(\mathrm{M}^{+}, 27\right), 183$ (100), 154 (24), 130 (30); HMRS calcd for $\mathrm{C}_{16} \mathrm{H}_{18} \mathrm{~N}_{2} \mathrm{O} 254.1419$, found 254.1416.

$(1 R, 5 S, 12 S)-N$-(Benzyloxycarbonyl)-12-ethyl-3-oxo1,2,3,4,5,6-hexahydro-1,5-methanoazocino $[4,3-b]$ indole (55). $\mathrm{BH}_{3} \cdot \mathrm{Me}_{2} \mathrm{~S}\left(100 \mu \mathrm{L}\right.$ of a $5 \mathrm{M}$ solution in $\left.\mathrm{Et}_{2} \mathrm{O}, 0.49 \mathrm{mmol}\right)$ was added to a cooled solution $\left(0{ }^{\circ} \mathrm{C}\right)$ of $53(120 \mathrm{mg}, 0.47 \mathrm{mmol})$ in toluene $(2.5 \mathrm{~mL})$, and the mixture was heated at reflux for $6 \mathrm{~h}$. Then, the mixture was cooled, $10 \%$ aqueous $\mathrm{CaCO}_{3}(2 \mathrm{~mL})$ was added, and stirring was continued for $20 \mathrm{~min}$. The layers were separated, and the organic layer was dried and concentrated to give $110 \mathrm{mg}(97 \%)$ of the tetracyclic amine. To a solution of this amine $(110 \mathrm{mg}, 0.46 \mathrm{mmol})$ in $\mathrm{CH}_{2} \mathrm{Cl}_{2}(7 \mathrm{~mL})$ were added $\mathrm{CaCO}_{3}(164 \mathrm{mg})$ and benzyloxycarbonyl chloride ( $236 \mu \mathrm{L}$ of a $50 \%$ solution in toluene, $0.7 \mathrm{mmol}$ ). The mixture was stirred at rt for $90 \mathrm{~min}$, poured into water, and extracted with $\mathrm{CH}_{2} \mathrm{Cl}_{2}$. The combined organic extracts were dried and concentrated to give and oil, which was chromatographed (4:6 $\mathrm{Et}_{2} \mathrm{O}$-hexane) to afford $\mathbf{5 5}(72 \mathrm{mg}, 41 \%):[\alpha]^{22} \mathrm{D}+89.0(c 0.33$, $\left.\mathrm{CHCl}_{3}\right)\left(\right.$ lit. ${ }^{4 \mathrm{a}}[\alpha]^{22} \mathrm{D}+89.4\left(\right.$ c $\left.0.4, \mathrm{CHCl}_{3}\right)$ ).

\section{Computational Methods}

The generalized molecular interaction potential with polarization (GMIPp) ${ }^{22}$ was used to investigate the reactivity pattern of unsaturated lactams cis-2 and 10. The GMIPp functional computes the interaction energy between the molecule, which is treated at the quantum mechanical (QM) level, and a classical probe. Such an interaction energy is expressed as the addition of three terms (see eq 1): (i) the electrostatic contribution between the QM charge distribution of the isolated molecule and the classical particle; (ii) a polarization contribution determined from perturbation theory; and (iii) a classical dispersion-repulsion term. In eq $1, R_{\mathrm{A}}$ and $R_{\mathrm{B}}$ stand for the positions of the nuclei $\left(Z_{\mathrm{A}}\right)$ in the molecule and of the atoms in the classical probe, $C_{\mu i}$ denotes the coefficient of atomic orbitals in the molecular orbital-linear combination of atomic orbitals, $P_{\mu \nu}$ is the first-order density matrix, $\phi$ is the set of atomic orbitals, $\xi$ denotes the energy of molecular orbitals, and $\epsilon$ and $R^{*}$ are the van der Waals parameters. The QM molecule was described at the Hartree-Fock (HF) level using the $6-31 \mathrm{G}(\mathrm{d})$ basis,${ }^{29}$ and the van der Waals parameters were taken from an in-house quantum mechanical-molecular mechanical parametrization. ${ }^{30}$ The classical particle was de- fined by a nonpolarizable point charge of -1 units of electron and van der Waals parameters of a carbon atom. The parameters $\epsilon_{\mathrm{AB}}$ and $R^{*} \mathrm{AB}$ were computed from the atomic parameters using the relationships $\epsilon_{\mathrm{AB}}=\left(\epsilon_{\mathrm{A}} \epsilon_{\mathrm{B}}\right)^{1 / 2}$ and $R^{*}{ }_{\mathrm{AB}}=R^{*}{ }_{\mathrm{A}}+R^{*}{ }_{\mathrm{B}}$. GMIPp calculations were performed on the most stable conformation of the lactams. To this end, a preliminary exploration was performed at the molecular mechanical level using the CVFF91 $1^{31}$ force field implemented in the Insight$\mathrm{II}^{32}$ program, and the geometry of the selected conformers was subsequently optimized at the HF/6-31G(d) level. GMIPp calculations were performed using MOPETE program. ${ }^{33}$

$$
\begin{aligned}
& \operatorname{GMIPp}=\sum_{A} \frac{Z_{\mathrm{A}}}{\left|R_{\mathrm{B}}-R_{\mathrm{A}}\right|}-\sum_{i}^{\text {occ }} \sum_{\mu} \sum_{\nu} P_{\mu \nu}\left|\phi_{\mu}\right| \frac{1}{\left|R_{\mathrm{B}}-r\right|}\left|\phi_{\nu}\right\rangle+ \\
& \sum_{i}^{\text {occ vir }} \sum_{j} \frac{1}{\xi_{i}-\xi_{j}}\left\{\sum_{\mu} \sum_{\nu} c_{\mu i} c_{v j}\left\langle\phi_{\mu}\left|\frac{1}{\left|R_{\mathrm{B}}-r\right|}\right| \phi_{\nu}\right\rangle\right\}^{2}+ \\
& \sum_{A} \epsilon_{\mathrm{AB}}\left[\left(\frac{R^{*}{ }_{\mathrm{AB}}}{\left|R_{\mathrm{B}}-R_{\mathrm{A}}\right|}\right)^{12}-2\left(\frac{R^{*} \mathrm{AB}}{\left|R_{\mathrm{B}}-R_{\mathrm{A}}\right|}\right)^{6}\right]
\end{aligned}
$$

The energetics of the conjugate addition of the anion derived from 18 to the lactams was examined from B3LYP ${ }^{34}$ calculations using the $6-31 \mathrm{G}(\mathrm{d})$ basis set. For the sake of completeness, calculations were also performed for the addition of methyl anion to the lactams. The geometry of the reactants and the enolate adducts formed from the conjugate addition reaction were fully optimized, and in all cases the minimum energy nature of the optimized geometries was confirmed from the inspection of the harmonic vibrational frequencies. Calculations were performed using Gaussian-98. ${ }^{35}$

Acknowledgment. Financial support from the DGICYT, Spain (Project No. BQU2003-00505), and the CUR, Generalitat de Catalunya (Grant No. 2001SGR-0084), is gratefully acknowledged. Thanks are also due to the Ministry of Education, Culture and Sport for a fellowship to M.P. and to DSM Deretil (Almería, Spain) for the generous gift of $(R)$-phenylglycine.

Supporting Information Available: X-ray crystallographic data for compounds $\alpha R$-11a, 26a, 26b, and 31b (CIF), complete details of computational methods, and general experimental procedures and experimental details and characterization data for compounds ent-9-ent-12, 21-33, and 35-49. This material is available free of charge via the Internet at http://pubs.acs.org.

JO0487101

(29) Hariharan, P. C.; Pople, J. A. Theor. Chim. Acta 1973, 28, 213. (30) Alhambra, C.; Luque, F. J.; Orozco, M. J. Phys. Chem. 1995 99,3084

(31) Maple, J. R.; Dinur, U.; Hagler, A. T. Proc. Natl. Acad. Sci. U.S.A. 1988, 85, 5350 .

(32) Insight-II (version 97.0), Molecular Simulations, San Diego, 1997.

(33) Mopete. Luque, F. J.; Alhambra, C.; Orozco, M. University of Barcelona, 2001.

(34) (a) Becke, A. D. Phys. Rev. A 1988, 38, 3098. (b) Lee, C.; Yang, W.; Parr, R. G. Phys. Rev. B 1988, 37, 785.

(35) Gaussian 98. Rev. A.7. Frisch, M. J.; Trucks, G. W.; Schlegel, H. B.; Scuseria, G. E.; Robb, M. A.; Cheeseman, J. R.; Zakrzewski, V. G.; Montgomery, J. A., Jr.; Stratmann R. E.; Burant, J. C.; Dapprich, S.; Millam, J. M.; Daniels, A. D.; Kudin, K. N.; Strain, M. C.; Farkas O.; Tomasi, J.; Barone, V.; Cossi, M.; Cammi, R.; Mennucci, B.; Pomelli, C.; Adamo, C.; Clifford, S.; Ochterski, J.; Petersson, G. A.; Ayala, P. Y.; Cui, Q.; Morokuma, K.; Malick, D. K.; Rabuck, A. D.; Raghavachari, K.; Foresman, J. B.; Cioslowski, J.; Ortiz, J. V.; Baboul, A. G.; Stefanov, B. B.; Liu, G.; Liashenko, A.; Piskorz, P.; Komaromi, I.; Gomperts, R.; Martin, R. L.; Fox, D. J.; Keith, T.; Al-Laham, M. A.; Peng, C. Y.; Nanayakkara, A.; Gonzalez, C.; Challacombe, M.; Gill, P. M. W Johnson, B.; Chen, W.; Wong, M. W.; Andres, J. L.; Gonzalez, C.; HeadGordon, M.; Replogle, E. S.; Pople, J. A. Gaussian, Inc., Pittsburgh, PA, 1998. 